\title{
National Assessment of Shoreline Change-Historical Shoreline Change Along the North Coast of Alaska, Icy Cape to Cape Prince of Wales
}

Open-File Report 2019-1146 
Cover. Aerial photograph of the community of Point Lay on the north coast of Alaska from 2009. Photograph from Gibbs and Richmond (2010). 


\section{National Assessment of Shoreline Change- Historical Shoreline Change Along the North Coast of Alaska, Icy Cape to Cape Prince of Wales}

By Ann E. Gibbs, Alexander G. Snyder, and Bruce M. Richmond

Open-File Report 2019-1146 


\title{
U.S. Department of the Interior DAVID BERNHARDT, Secretary
}

\author{
U.S. Geological Survey \\ James F. Reilly II, Director
}

\section{U.S. Geological Survey, Reston, Virginia: 2019}

For more information on the USGS - the Federal source for science about the Earth, its natural and living resources, natural hazards, and the environment—visit https://www.usgs.gov or call 1-888-ASK-USGS (1-888-275-8747).

For an overview of USGS information products, including maps, imagery, and publications, visit https://store.usgs.gov.

Any use of trade, firm, or product names is for descriptive purposes only and does not imply endorsement by the U.S. Government.

Although this information product, for the most part, is in the public domain, it also may contain copyrighted materials as noted in the text. Permission to reproduce copyrighted items must be secured from the copyright owner.

Suggested citation:

Gibbs, A.E., Snyder, A.G., and Richmond, B.M., 2019, National assessment of shoreline change-Historical shoreline change along the north coast of Alaska, Icy Cape to Cape Prince of Wales: U.S. Geological Survey Open-File Report 2019-1146, 52 p., https://doi.org/10.3133/ofr20191146.

Associated data for this publication:

Snyder, A.G., and Gibbs, A.E., 2019, National assessment of shoreline change-A GIS compilation of updated vector shorelines and associated shoreline change data for the north coast of Alaska, Icy Cape to Cape Prince of Wales: U.S. Geological Survey data release, https://doi.org/10.5066/PgH1S1PV.

ISSN 2331-1258 (online) 


\section{Acknowledgments}

This report was made possible by the hard work and generous cooperation of many individuals. We thank the National Oceanic and Atmospheric Administration (NOAA) for providing digital historical shorelines and scans of selected NOAA topographic sheets (T-sheets). William Manley and Leanne Lestak (University of Colorado, Boulder, Institute of Arctic and Alpine Research) provided shoreline data for the Arctic National Parks. Matt Nolan of Fairbanks Fodar acquired the 2015 and 2016 imagery. Marc Berghouse provided technical support. Amy Foxgrover and Rachel Henderson of the U.S. Geological Survey and Jaqueline Overbeck of the Alaska Division of Geological and Geophysical Surveys provided helpful reviews of an earlier version of this manuscript.

\section{Contents}

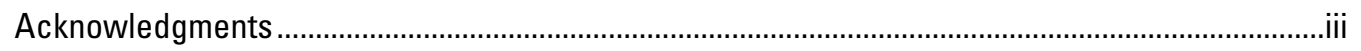

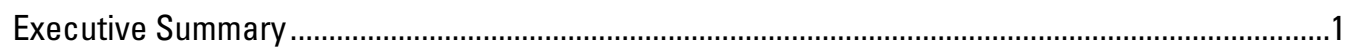

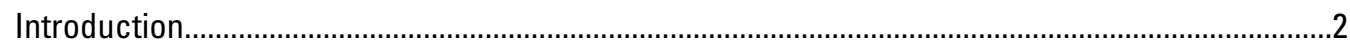

U.S Geological Survey National Assessment of Shoreline Change Project.............................2

The Role of State and Federal Governments ......................................................................

Previous National and Northwestern Alaska Shoreline Assessments ................................................

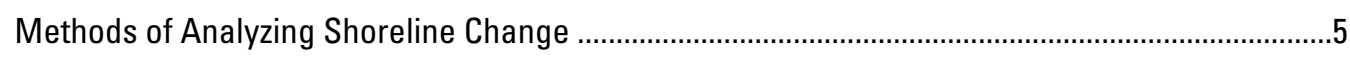

Compilation of Historical Shorelines ..............................................................................

1950s-Era Shorelines ..............................................................................................

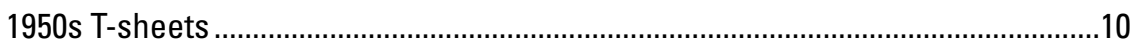

1950s Black and White Aerial Photography …………………..............................10

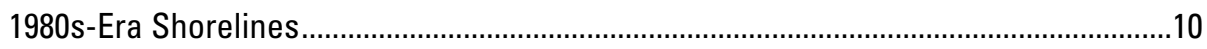

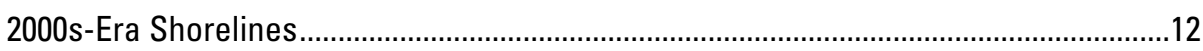

2010s-Era Shorelines................................................................................................12

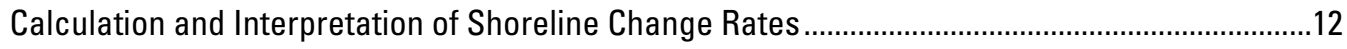

Estimation of Shoreline Position Uncertainty .................................................................

Estimation of Shoreline Change Rate Uncertainty at Individual Transects ............................14

Estimation of Regionally Averaged Shoreline Change Rate Uncertainty................................14

Results from Analysis of Historical Shoreline Change ...................................................................16

Region 1: Icy Cape to Amatusuk Creek .............................................................................18

Region 2: Amatusuk Creek to Cape Lisburne ………..............................................................22

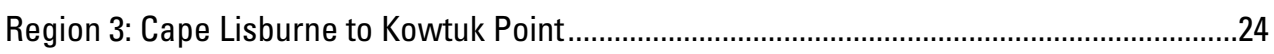

Region 4: Kowtuk Point to Cape Thompson (Point Hope) .....................................................2

Region 5: Cape Thompson to Asikpak Lagoon .........................................................................

Region 6: Asikpak Lagoon to Sheshalik Spit (Cape Krusenstern National Monument)..........33

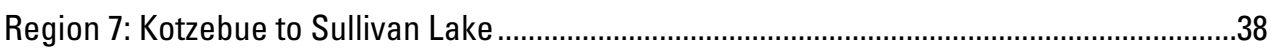

Region 8: Sullivan Lake to Cape Prince of Wales (Bering Land Bridge National Preserve) ..43

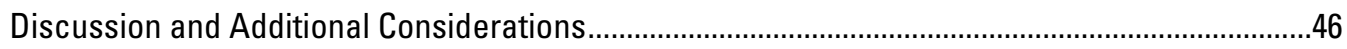

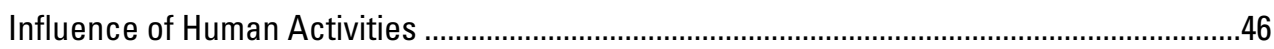

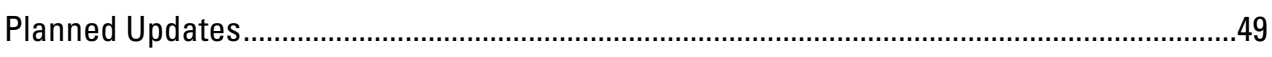

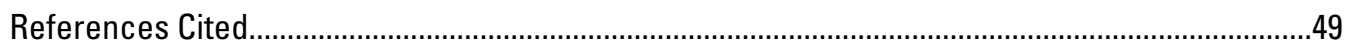




\section{Figures}

1. Shaded-relief map of the north coast of Alaska showing the boundaries of northern Alaska shoreline change studies and key geographic locations. .3

2. Map showing the relief and major physiographic provinces of northern Alaska .............4

3. Shaded-relief map of the northwest coast of Alaska showing key geographic locations and boundaries of the eight study regions in this report.

4. Maps of the northwest coast of Alaska showing the shoreline data sources and gaps used in this report..

5. Aerial photographs showing examples of the coast in region $1 \ldots \ldots \ldots \ldots \ldots \ldots \ldots \ldots \ldots \ldots \ldots \ldots \ldots . . .18$

6. Map showing color-coded shoreline types in region 1.................................................19

7. Map showing color-coded shoreline change rates in region 1 .....................................20

8. Map showing color-coded shoreline change rates near the community of Point Lay...21

9. Aerial photographs showing examples of the coast in region 2 .................................22

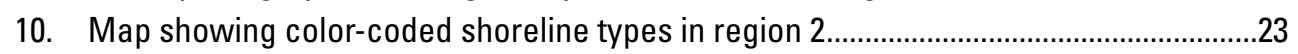

11. Map showing color-coded shoreline change rates in region 2......................................23

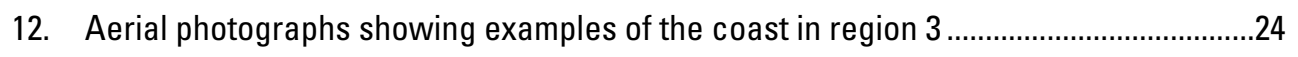

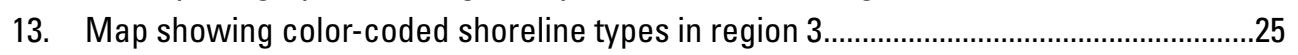

14. Map showing color-coded shoreline change rates in region 3.....................................26

15. Aerial photographs showing examples of the coast in region 4 ..................................27

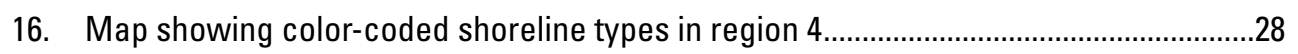

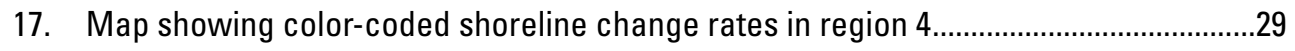

18. Map showing color-coded shoreline change rates near the community of Point Hope ........30

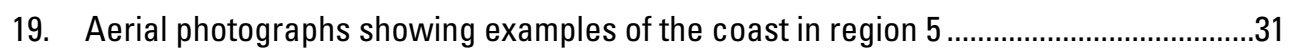

20. Map showing color-coded shoreline types in region 5................................................32

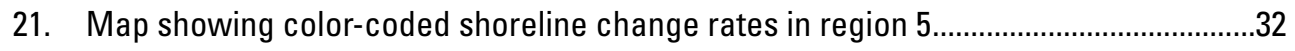

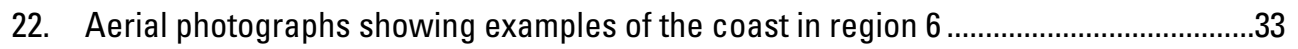

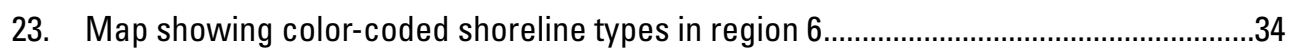

24. Map showing color-coded shoreline change rates in region 6 ......................................35

25. Map showing color-coded shoreline change rates near Red Dog Dock........................36

26. Map showing color-coded shoreline change rates near the community of Kivalina .....37

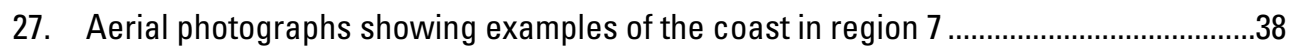

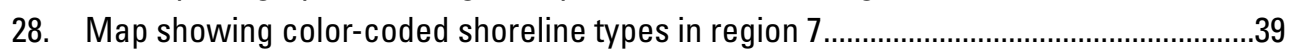

29. Map showing color-coded shoreline change rates in region 7.....................................40

30. Map showing color-coded shoreline change rates near the community of Kotzebue ...41

31. Map showing color-coded shoreline change rates near the community of Deering.....42

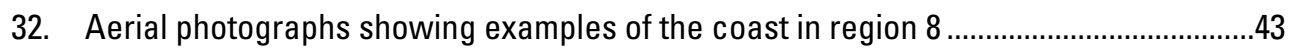

33. Map showing color-coded shoreline types in region 8....................................................4

34. Map showing color-coded shoreline change rates in region 8......................................4

35. Map showing color-coded shoreline change rates near the community of Shishmaref.........45

36. Map showing color-coded shoreline change rates near the community of Wales.........47

37. Shaded-relief map of the north coast of Alaska study area showing color-coded, long-term shoreline change rates from Icy Cape to Cape Prince of Wales. 


\section{Tables}

1. Sources of historical shoreline data for the northwest coast of Alaska ................................6

2. Shorelines used to calculate shoreline change rates by coastal segment...........................8

3. Measurement uncertainties associated with all datasets ......................................................11

4. Daily water level deviation from mean high water measured at the Red Dog Dock tidal station and calculated change in shoreline position.

5. Summary of average shoreline change rates, average rate uncertainties, and percentage of transects eroding for the study area and each region relative to shoreline type.................15

6. Long- and short-term maximum shoreline change rates by region ......................................17

\section{Conversion Factors}

International System of Units to U.S. customary units

\begin{tabular}{lll}
\hline \multicolumn{1}{c}{ Multiply } & By & To obtain \\
\hline centimeter $(\mathrm{cm})$ & \multicolumn{2}{c}{ Length } \\
meter $(\mathrm{m})$ & 0.3937 & inch $(\mathrm{in})$. \\
kilometer $(\mathrm{km})$ & 3.281 & foot $(\mathrm{ft})$ \\
meter $(\mathrm{m})$ & 0.6214 & mile $(\mathrm{mi})$ \\
& 1.094 & yard $(\mathrm{yd})$ \\
\hline meter per year $(\mathrm{m} / \mathrm{yr})$ & \multicolumn{2}{c}{ Flow rate } \\
\hline
\end{tabular}

\section{Datum}

All positional measurements were made in the Universal Transverse Mercator (UTM) coordinate system on the North American Datum of 1983 (NAD 83). Data provided with this report were reprojected to the geographic coordinate system on the World Geodetic System of 1984 (WGS 84) ellipsoid using the WGS_1984_(ITRF00)_To_NAD_1983 transformation in Esri ArcGIS version 10.5 .

\section{Abbreviations}

$\begin{array}{ll}\text { AHAP } & \text { Alaska High-Altitude Aerial Photography } \\ \text { aHWL } & \text { approximate mean high water line } \\ \text { DEW } & \text { Distant Early Warning radar site } \\ \text { DO00 } & \text { Digital Orthophoto Quarter Quadrangles } \\ \text { FEMA } & \text { Federal Emergency Management Agency }\end{array}$




$\begin{array}{ll}\text { GPS } & \text { Global Positioning System } \\ \text { HWL } & \text { high water line } \\ \text { km } & \text { kilometers } \\ \text { lidar } & \text { light detection and ranging } \\ \text { MHW } & \text { mean high water } \\ \mathrm{m} & \text { meters } \\ \text { m/yr } & \text { meters per year } \\ \text { NASC } & \text { National Assessment of Shoreline Change } \\ \text { NGS } & \text { National Geodetic Survey } \\ \text { NOAA } & \text { National Oceanic and Atmospheric Administration } \\ \text { NOS } & \text { National Ocean Service } \\ \text { NWS } & \text { North Warning System radar site } \\ \text { RMSE } & \text { root mean square error } \\ \text { SDMI } & \text { Alaska Statewide Digital Mapping Initiative } \\ \text { T-sheet } & \text { topographic sheet } \\ \text { USACE } & \text { U.S. Army Corps of Engineers } \\ \text { USGS } & \text { U.S. Geological Survey }\end{array}$




\title{
National Assessment of Shoreline Change-Historical Shoreline Change Along the North Coast of Alaska, Icy Cape to Cape Prince of Wales
}

\author{
By Ann E. Gibbs, Alexander G. Snyder, and Bruce M. Richmond
}

\section{Executive Summary}

Beach erosion is a persistent problem along most open-ocean shores of the United States. Along the Arctic coast of Alaska, coastal erosion is widespread and threatens communities, defense and energy-related infrastructure, and coastal habitat. As coastal populations continue to expand and infrastructure and habitat are increasingly threatened by erosion, there is increased demand for accurate information regarding past and present trends and rates of shoreline movement. There is also a need for a comprehensive analysis of shoreline change with metrics that are consistent from one coastal region to another. To meet these national needs, the U.S. Geological Survey (USGS) is conducting an analysis of historical shoreline positions along the open-ocean sandy shores of the conterminous United States and parts of Hawaii, Alaska, and the Great Lakes. One purpose of this work is to develop standard, repeatable methods for mapping and analyzing shoreline positions so that periodic, systematic, and internally consistent updates regarding coastal erosion and land loss can be made nationally.

This report is one in a series of regionally focused reports on historical shoreline change. Previous investigations include analyses and descriptive reports for the coasts of the U.S. Gulf of Mexico, Southeast Atlantic, California, New England and Mid-Atlantic, parts of Hawaii, and the Pacific Northwest coasts of Oregon and Washington. Similar to earlier reports in the series, this report summarizes the methods of analysis, documents and describes the results of the analysis, and explains historical trends and rates of shoreline change.

This is the second USGS report documenting rates of historical shoreline change along the north coast of Alaska and extends the initial assessment from the United States-Canada Border to Icy Cape, an additional $\sim 1,250$ kilometers south to Cape Prince of Wales. The Alaska shoreline change assessments differ from other USGS shoreline change assessments in that: (1) the earliest shoreline surveys in Alaska are from the late-1940s/early1950s, whereas for the rest of the Nation, shoreline surveys extend back to the late 1800s; (2) modern (2010s era) shorelines in this study represent a visually derived land-water interface position versus an elevation based, tidally referenced shoreline position; and (3) both exposed open-ocean and sheltered mainlandlagoon shorelines and rates of change are included in this study compared to other locations where only exposed open-ocean sandy shorelines or bluff edges were evaluated. No distinction was made between sand or gravel beaches, and the base of the unconsolidated coastal bluff was considered the shoreline where no fronting beach existed.

Shoreline change was evaluated by comparing three to four historical shoreline positions derived from 1950s-era (1947 to 1952) topographic surveys and black and white aerial photography, 1980s-era (1978 to 1985) color-infrared Alaska High-Altitude Aerial Photography, 2003 natural color aerial photography, and 2010s-era (2015 and 2016) natural color aerial photography. Long-term (1950s-2010s) and short-term (1980s-2010s) shoreline change rates were calculated using linear-regression and end-point methods, respectively, at transects spaced approximately every 50 meters along both the mainland and barrier island coasts. Shorelines were not delineated nor change rates calculated for river deltas because of the high natural variability and complexity of these shoreline reaches. The rates of change presented in this report represent only conditions up to the date of the most recent shoreline data and are not intended for predicting future shoreline positions or rates of change.

The study area was subdivided into a total of eight regions based on data availability, geomorphology, and for the purpose of presenting regional shoreline change trends. In order to maintain consistency with other National Assessment of Shoreline Change reports, the term "erosion" is used in this study to indicate the measured landward movement or retreat of the shoreline. No distinction is made between physical erosion and land loss or shoreline retreat as a result of breaching of coastal lake shorelines or flooding of the coast caused by sea-level rise or land subsidence; in this context, erosion and retreat are interchangeable. Accretion is the measured seaward progradation of the shoreline and, particularly in the case of barrier islands and spits, also may represent the migration alongshore of a landscape feature.

Shoreline change rates calculated on more than 24,000 individual transects indicate that between 1948 and 2016 the northern coast of Alaska between Icy Cape and Cape Prince of Wales was slightly erosional, with 68 percent of the total transects showing shoreline retreat over the long term and 63 percent over the short term. However, only 9 percent of the total transects showed shoreline retreat greater than 1 meter 
per year $(\mathrm{m} / \mathrm{yr})$ over the long and short term, respectively. Mean rates of shoreline change of $-0.2 \pm 0.1$ and $-0.2 \pm 0.3 \mathrm{~m} /$ $\mathrm{yr}$, were calculated for the long and short term, respectively. Many rates measured were near the limit of our shoreline change uncertainty estimates. Erosion and accretion rates on individual transects ranged from -8.3 to $+9.6 \mathrm{~m} / \mathrm{yr}$ over the long term and -16.0 to $+20.0 \mathrm{~m} / \mathrm{yr}$ over the short-term analysis periods. The highest rates of erosion and accretion were associated with the formation and migration of inlets along barrier island coasts. The highest erosional rates of change were measured in the southern part of the study area between Sullivan Lake and Cape Prince of Wales. The highest accretional rates of change were measured in the northern part of the study area on the open-ocean coast of barrier islands fronting Kasegaluk Lagoon.

Open-ocean exposed shorelines compose 85 percent of all transects and 70 percent were erosional over the long term. Sheltered mainland-lagoon shorelines compose 15 percent of all transects in the study area and 58 percent were erosional over the long term. Although mean shoreline change rates were quite low along all coasts, exposed shorelines retreated at twice the rate $(-0.2 \pm 0.1 \mathrm{~m} / \mathrm{yr})$ of sheltered shorelines $(-0.1 \pm 0.1 \mathrm{~m} / \mathrm{yr})$. Barrier shoreline transects (includes barrier islands, spits, and beaches) compose 49 percent of the total transects and 56 percent of all exposed shoreline transects. Mean shoreline change rates on exposed barrier shorelines were only slightly greater than exposed mainland shorelines $(-0.3 \pm 0.1$ and $-0.2 \pm 0.1 \mathrm{~m} / \mathrm{yr}$, respectively). Mean shoreline change rates on sheltered barrier shorelines were similar to sheltered mainland shorelines $(-0.1 \pm 0.3 \mathrm{~m} / \mathrm{yr})$.

In contrast to the majority of the Nation's shorelines, for all but three months of the year (July-September), the north coast of Alaska has historically been protected by landfast sea ice from processes such as waves, winds, and currents that typically drive coastal change on beaches in more temperate regions of the world. Projected and observed increases in periods of seaice-free conditions, as sea ice melts earlier and forms later in the year, particularly in the autumn, when large storms are more common in the Arctic, suggest that Arctic coasts will be more vulnerable to storm surge and wave energy, potentially resulting in accelerated shoreline erosion and terrestrial habitat loss in the future. Increases in air and sea water temperatures may also increase erosion of the ice-rich, coastal permafrost bluffs present along much of Alaska's Arctic coast. More frequent shoreline change data collection and analysis in this rapidly changing environment should be considered in order to evaluate shoreline change trends in the future.

Geospatial data (Snyder and Gibbs, 2019) associated with this Open-File Report are available online at https:// doi.org/10.5066/P9H1S1PV and the USGS Coastal Change Hazards Portal at https://marine.usgs.gov/ coastalchangehazardsportal/.

\section{Introduction}

\section{U.S Geological Survey National Assessment of Shoreline Change Project}

Beaches are a dynamic interface between water and land and are frequently subjected to a range of natural hazards, which include flooding, storm effects, and coastal erosion. The U.S. Geological Survey (USGS) is conducting a national assessment of coastal change hazards across the Nation. One component of this research effort, the National Assessment of Shoreline Change Project, documents changes in shoreline position as a proxy for coastal change. Shoreline position is one of the most commonly monitored indicators of environmental change (for example, Dolan and others, 1991; Fletcher, 1992; Morton, 1996; Douglas and others, 1998; Galgano and others, 1998), and it is an easily understood feature marking the location of a beach through time.

A principal component of the USGS National Assessment of Shoreline Change (NASC) has been to develop a consistent methodology for calculating shoreline change rates and reporting results that may be periodically updated when additional data or improved techniques are available. The primary objectives of the national assessment are to conduct research on improved methods of assessing and monitoring shoreline movement and develop a better understanding of the processes controlling shoreline change. Achieving these ongoing long-term objectives requires research that (1) examines the original sources of shoreline data (maps, aerial photographs, Global Positioning System [GPS], and light detection and ranging [lidar]); (2) evaluates the use of different shoreline proxies (geomorphic feature, water mark, tidal datum, and elevation), including the errors associated with each data source; (3) investigates bias and potential errors associated with integrating different shoreline proxies from different sources; (4) develops standard, uniform methods of shoreline change analysis; (5) examines the effects of localized human activities on shoreline movement and rates of change; and (6) integrates shoreline change observations with other information, such as geologic framework and sediment transport data.

Results of the NASC project are organized by coastal regions. Previous investigations include analyses and descriptive reports, as well as the geographic information system data used in the analyses for the north coast of Alaska between the United States-Canada Border and Icy Cape (Gibbs and Richmond, 2015; Gibbs and Richmond, 2017; Gibbs and others, 2017), Pacific Northwest (Kratzmann and others, 2013; Ruggiero and others, 2013), the Hawaiian Islands (Fletcher and others, 2012; Romine and others, 2012), the New England and Mid-Atlantic coasts (Hapke and others, 2010; Himmelstoss and others, 2010), California (Hapke and others, 2006, 2008; Hapke and Reid, 2006, 2007), the Southeastern United States coast (Miller and others, 2004, 2005; Morton and Miller, 2005; Himmelstoss and 
others, 2017), and the U.S. Gulf Coast (Morton and others, 2004; Himmelstoss and others, 2017).

This report summarizes historical change in shoreline positions along the north coast of Alaska from Cape Prince of Wales to Icy Cape. It extends the initial Alaska shoreline change assessment from the United States-Canada Border to Icy Cape (Gibbs and Richmond, 2015, 2017), an additional $\sim 1,250$ kilometers $(\mathrm{km})$ and completes a comprehensive assessment of historical shoreline change rates along Alaska's Arctic coast north of the Bering Strait (fig. 1). Major physiographic provinces of Alaska's coast north of the Bering Strait include the Arctic Coastal Plain, the Arctic Foothills, and the Seward Peninsula (fig. 2). The microtidal coast is in a zone of continuous permafrost (Jorgenson and others, 2008, 2015), with seasonal sea-ice conditions, and is very different than the other U.S. coastlines studied by the NASC project. Other differences between northern Alaska and previous NASC study sites are the relative lack of tourist beaches and coastal tourism infrastructure, limited historical datasets, poor geodetic control, and very limited information on water levels or tidal datums. This report documents the coastal change hazard at regional scales and strives to relate this hazard to the body of knowledge regarding coastal geology of the northern Alaska region. Coastal change can have substantial impacts on community infrastructure, natural and cultural resources, habitat of federally protected trust species (many of which are threatened or endangered), Department of Defense related infrastructure, and organic carbon, mercury, and nutrient input into the marine environment.

The Alaska shoreline data differ from shoreline data in previously published USGS reports as follows.

- The earliest shoreline surveys in Alaska are from the late-1940s/early-1950s, whereas for the rest of the Nation, shoreline surveys extend back to the late 1800s.

- 1980s-, 2000s-, and 2010s-era shorelines in this study represent a visually derived land-water interface position versus an elevation-based or tidally referenced shoreline position.

- Rates of shoreline change along both exposed open-ocean and sheltered mainland-lagoon coasts are included in this study, compared to other locations where only exposed openocean sandy shorelines or coastal cliff edges were evaluated.

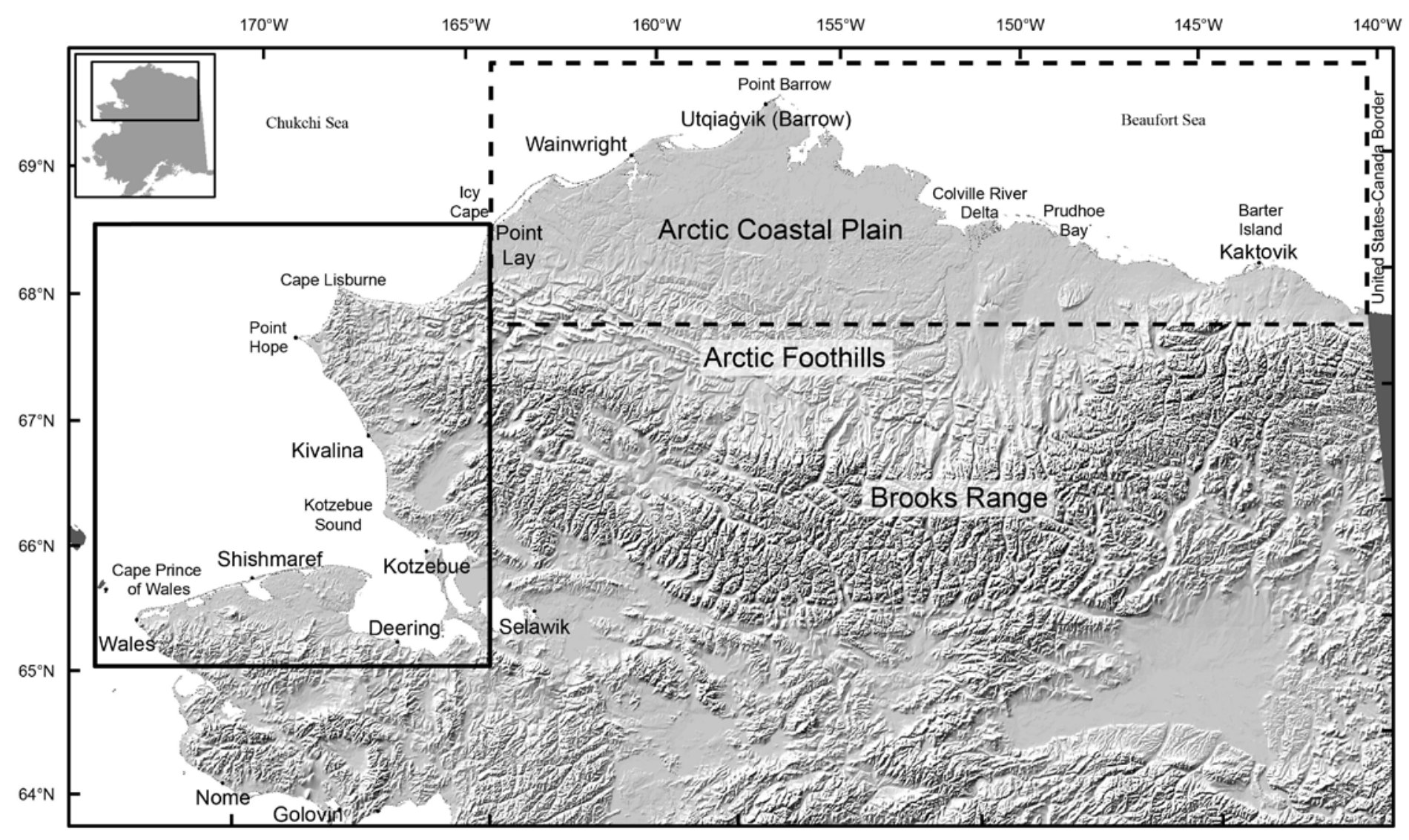

Figure 1. Shaded-relief map of the north coast of Alaska showing the boundaries of northern Alaska shoreline change studies and key geographic locations. The study area described in this report (Icy Cape to Cape Prince of Wales) is outlined by the solid black line. The area of previous shoreline change assessments (Gibbs and Richmond, 2015, 2017) is outlined by the dashed black line. Shaded relief from U.S. Geological Survey 300-meter digital elevation model. 


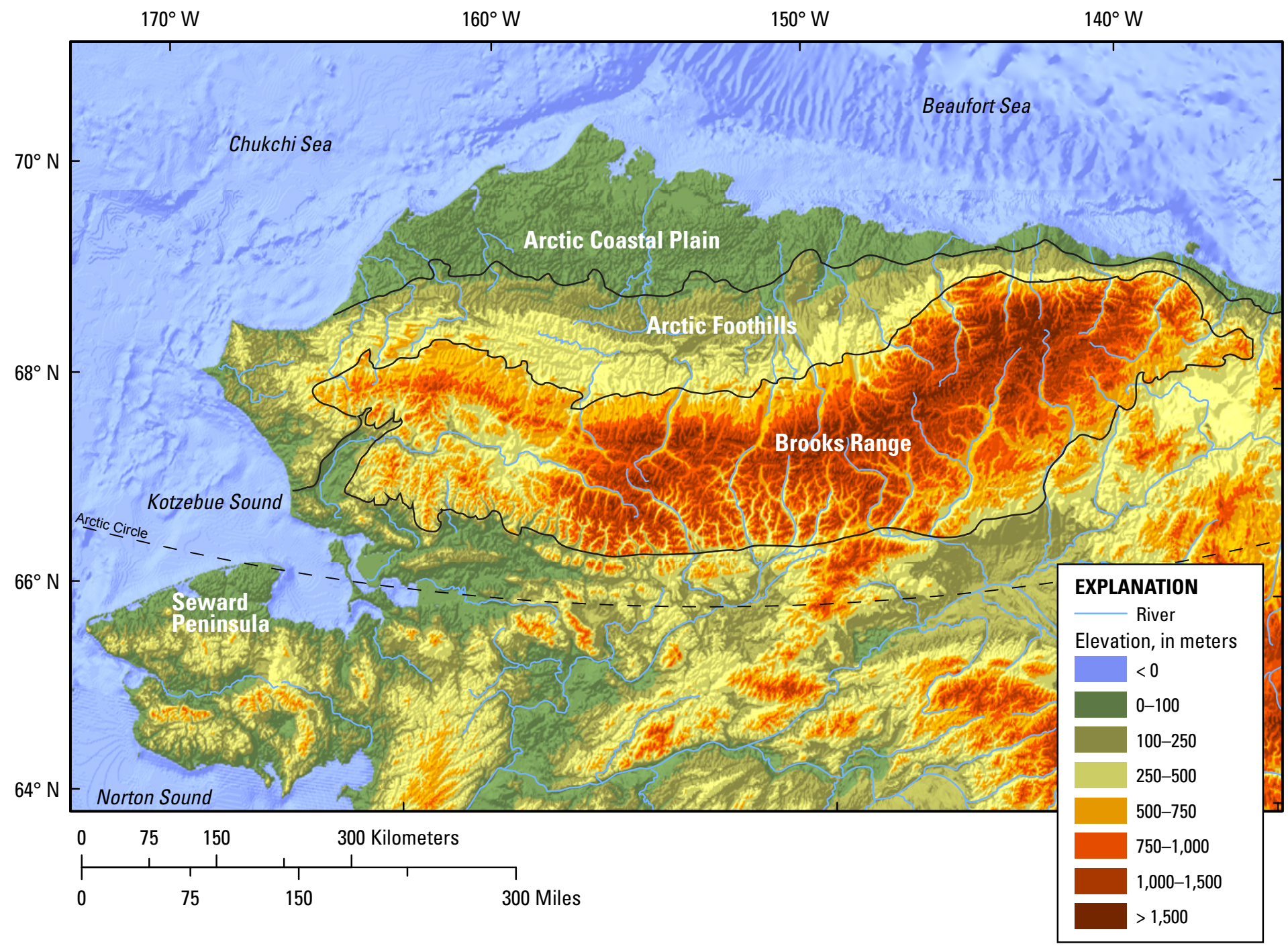

Figure 2. Map showing the relief and major physiographic provinces of northern Alaska (after Wahrhaftig, 1965).

\section{The Role of State and Federal Governments}

One reason for conducting this National Assessment of Shoreline Change is that there is no widely accepted, standardized method of analyzing shoreline change. Each State or region has its own data needs and coastal-zone management responsibilities (for example, construction set-back lines, dune protection zones, and public access) and, therefore, each State uses a different technique and standard to compile shorelines and calculate rates of shoreline movement. Consequently, calculated rates of shoreline change and projected erosion hazard zones are inconsistent from State to State and often cannot be compared directly. These inconsistencies were clearly demonstrated by the Federal Emergency Management Agency (FEMA)-sponsored erosion studies (Crowell and Leatherman, 1999) that were used as the basis for evaluating erosion hazards (The H. John Heinz III
Center for Science, Economics, and the Environment, 2000). The USGS National Assessment of Shoreline Change Project represents the first effort to compile shorelines from original data sources and calculate rates of shoreline change on a national scale using internally consistent methods. The results of the analyses allow direct comparison of rates of change from one coastal segment to another and form the basis for future comparison of shoreline position.

Several Federal agencies (USGS, FEMA, National Oceanic and Atmospheric Administration [NOAA], and U.S. Army Corps of Engineers [USACE]) have regulatory or administrative responsibilities pertaining to shorelines. Their responsibilities differ between agencies and require different approaches. They also offer substantial opportunities for cooperation. For example, the USACE is authorized and funded by Congress to report on the economic and environmental implications of shoreline change and the costs 
of erosion mitigation. Its National Shoreline Management Study (Stauble and Brumbaugh, 2003) is being conducted using existing shoreline data. The USGS shares data and information, such as lidar-derived shoreline and rates of change, in support of that effort. NOAA has a mandate to establish the official shoreline boundary for the Nation using tidal datums. The emphasis of NOAA's mandate is on safe navigation and using the shoreline to generate nautical charts. NOAA also conducts the VDatum program, which assists with datum transformations and shoreline delineation for various purposes. Congress authorized and funded FEMA to report on the economic effect of erosion hazards on coastal communities, and on claims to the National Flood Insurance Fund. To accomplish this goal, FEMA contracted with State agencies and academic researchers to conduct a pilot study of erosion hazards that included shoreline change data for limited geographic areas. The USGS is responsible for conducting research pertaining to coastal change hazards, understanding the processes that cause coastal change, and developing models to project future change. The USGS is the only Government agency that has a dedicated program to monitor coastal change into the future using consistent methods nationwide. This program is critically important for the assessment of National issues such as the coastal effects of sea-level rise and climate change.

\section{Previous National and Northwestern Alaska Shoreline Assessments}

The U.S. Army Corps of Engineers (USACE, 1971)

conducted the first National assessment of coastal erosion. That study identified areas of critical and non-critical erosion on the basis of economic development and potential for property loss, but rates of shoreline movement were not evaluated. Dolan and others (1985) conducted a comprehensive analysis of shoreline change for most of the United States. Their analysis was based on compilation of rates of shoreline change contributed by other investigators and derived from their own studies. Rates of change were presented and long-term trends of erosion and accretion were summarized. Most of the northwest coast of Alaska was mapped as having no data, however, the reach between Cape Lisburne and Cape Krusenstern was mapped as an area of episodic cliff retreat at rocky headlands with pocket beaches, and low (less than 1 meter per year [m/yr]) annual erosion and accretion was mapped at Cape Krusenstern.

Previous shoreline change studies in northwestern Alaska are limited but include:

- The Task Force on Erosion Control Final Report (Alaska Department of Transportation and Public Facilities, 1984), which examined erosion on a statewide scale and relied heavily on the insight of local officials and residents.
- The Alaska Village Erosion Technical Assistance Program Report (USACE, 2006) examined erosion conditions at seven Alaskan communities: Bethel, Dillingham, Kaktovik, Kivalina, Newtok, Shishmaref, and Unalakleet.

- The Alaska Baseline Erosion Assessment (USACE, 2009), was conducted to coordinate, plan, and prioritize appropriate responses to erosion at communities throughout Alaska. The study began in April 2005 and completed in March 2009.

- Lestak and others (2010) completed a detailed and quantitative assessment of historical shoreline change in the coastal Arctic national parks (Bering Land Bridge National Preserve and Cape Krusenstern National Monument) using aerial photography from the 1950s, 1980s, and 2003. They utilized the same shoreline proxy (instantaneous land-water interface) and methodologies for delineating shorelines and calculating shoreline change rates as used in this assessment and we use their shoreline data (Manley and others, 2010) in this analysis.

- Lantuit and others (2011) published the Arctic Coastal Dynamics Database, a detailed geomorphological classification scheme, including coastal change rates, derived from a variety of sources, for the entire Arctic coast, including the American Chukchi and Beaufort Seas.

- Farquharson (2017) extended the coastal change analysis in Bering Land Bridge National Preserve and Cape Krusenstern National Monument by adding 2014 satellite imagery; however, they used a different shoreline proxy (erosional scarp) to determine their change rates and thus their datasets and results are not directly comparable with this assessment.

\section{Methods of Analyzing Shoreline Change}

\section{Compilation of Historical Shorelines}

Coastal researchers in universities and governmental agencies in the United States have been quantifying rates of shoreline movement and studying coastal change for decades. Time series of shoreline positions can be used to document coastal change and are interpreted to improve our understanding of shoreline stability. Before GPS and lidar technologies were developed, the most commonly used sources of historical shoreline position were NOAA topographic sheets (T-sheets) (Shalowitz, 1964) and aerial photographs. Extraction of shoreline position from these data 
sources involves georeferencing maps or aerial photographs and subsequently interpreting and digitizing a shoreline position. Depending on location, data source, and scientific preference, different proxies for shoreline position (shoreline reference feature) are used to document coastal change, including high water line (HWL), wet-dry line, vegetation line, dune toe or crest, toe or berm of the beach, cliff base or top, the line of mean high water (MHW), or a tide-coordinated or instantaneous land-water interface.

This study incorporates shoreline positions for four periods, circa-1950s, circa-1980s, circa-2000s (only in and adjacent to Cape Krusenstern National Monument and Bering Land Bridge National Preserve), and circa-2010s derived from a variety of dates and data sources (table 1, fig. 3). Datasets were selected based on the availability of georeferenced, temporally consistent, regional-scale, digital source data. Shorelines were not digitized over deltaic regions or intertidal mudflats because of large uncertainties in identifying waterline intersections on gently sloping coasts.

The shoreline reference features, or shoreline proxy, mapped in this study were the "approximate mean high water line" (aHWL) as defined and mapped on the 1950sera T-sheets and the instantaneous land-water interface (the intersection of the water line and the beachface) on the 1950s-, 1980s-, 2000s-, and 2010s-era aerial photography (table 2). Where no beach was identifiable in the imagery, the marsh vegetation or bluff edge and water interface was digitized. The instantaneous land-water interface proxy shoreline was generally well defined in the 1950s, 2000s, and 2010s photographs, except where obscured by clouds, shadows, waves, or ice. It was less well defined in the 1980s Alaska High-Altitude Aerial Photography (AHAP) because of higher flying altitudes, lower resolution, and some data loss associated with the georeferencing technique.

The land-water interface is not an ideal feature to use as a shoreline proxy because of the potentially wide variations in the horizontal position of the shoreline caused by fluctuating water levels, which is especially pronounced in gently sloping environments. It was determined to be an acceptable proxy for this study because of the low tidal range in the region ( 21 centimeters [ 0.7 feet] diurnal range at Prudhoe Bay and 0.27 centimeters [ 0.9 feet] diurnal range at Red Dog Dock tidal stations; NOAA, 2018a, b) and the fact that common proxies for high water lines (for example, beach wrack, wet/ dry line, toe or berm of the beach) were difficult to delineate in the imagery owing to a number of factors, including narrow beaches, low contrast of beach sediment, low sun angles, and (or) a lack of debris material. Uncertainties associated with using the instantaneous land-water interface are included in the uncertainty analysis below.

Table 1. Sources of historical shoreline data for the northwest coast of Alaska.

[NOAA, National Oceanic and Atmospheric Administration; T-sheet, topographic sheet]

\begin{tabular}{|c|c|c|}
\hline Organization & Original data source & Spatial coverage \\
\hline $\begin{array}{l}\text { National Oceanic and Atmospheric } \\
\text { Administration Coastal Services Center }\end{array}$ & Scanned NOAA T-sheets $(1948,1949,1950,1951,1952)^{1}$ & $\begin{array}{l}\text { Icy Cape to Asikpak Lagoon; } \\
\text { Kotzebue to Sullivan Lake }\end{array}$ \\
\hline U.S. Fish and Wildlife Service & $\begin{array}{l}\text { Orthorectified 1:64,000-scale color-infrared Alaska High- } \\
\text { Altitude Aerial Photography }(1978,1980,1982,1985)^{2}\end{array}$ & Icy Cape to Asikpak Lagoon \\
\hline U.S. Geological Survey & $\begin{array}{l}\text { Orthorectified 1:64,000-scale color-infrared Alaska High- } \\
\text { Altitude Aerial Photography }(1978)^{3}\end{array}$ & Kotzebue to Sullivan Lake \\
\hline
\end{tabular}

${ }^{1}$ Non-georefernced NOAA shoreline survey scans (T-sheets and TP-sheets); https://nosimagery.noaa.gov/images/shoreline_surveys/survey_scans/NOAA_ Shoreline_Survey_Scans.html, accessed April 20, 2019.

${ }^{2}$ Orthorectified by S. Arko, University of Alaska Fairbanks, in 2014 under contract with the U.S. Fish and Wildlife Service.

${ }^{3}$ Orthorectified by S. Arko, Far North Geospatial LLC, in 2016 under contract with the U.S. Geological Survey.

${ }^{4}$ Fairbanks Fodar, under contract with the U.S. Geological Survey.

${ }^{5}$ Manley and others (2007a).

${ }^{6}$ Manley and others (2007b).

${ }^{7}$ Manley and others (2007c).

${ }^{8}$ Overbeck and others (2017). 


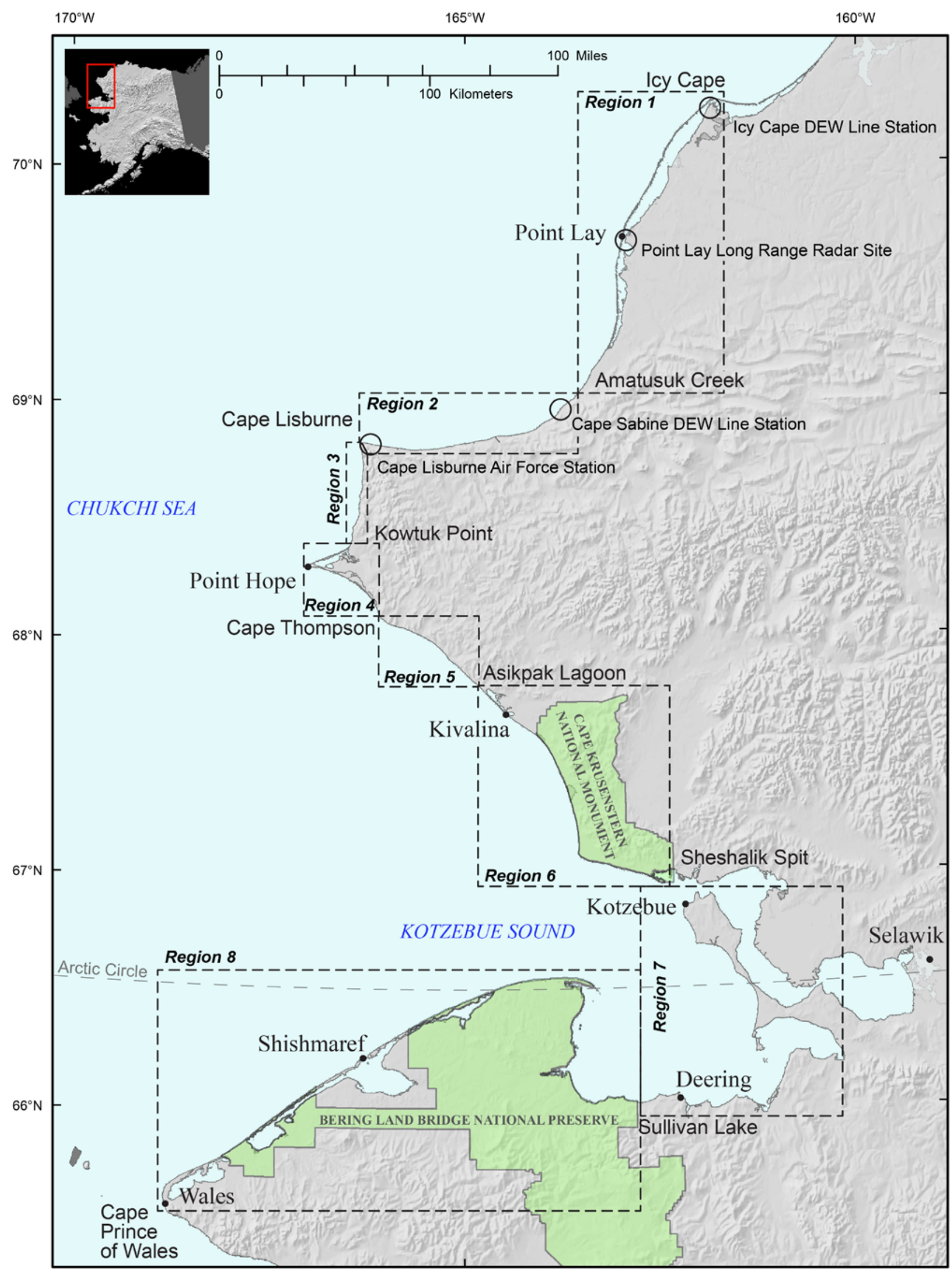

Figure 3. Shaded-relief map of the northwest coast of Alaska showing key geographic locations and boundaries of the eight study regions in this report (dashed outlines). Shaded relief from U.S. Geological Survey 300-meter digital elevation model. DEW, Distant Early Warning. 
Table 2. Shorelines used to calculate shoreline change rates by coastal segment.

[AHAP, Alaska High-Altitude Aerial Photography; aHWL, approximate mean high water line; B\&W, black and white; BELA, Bering Land Bridge National Preserve; CAKR, Cape Krusenstern National Monument; CIR, Color-infrared; LWI, instantaneous land-water interface; T-sheet, topographic sheet; NC, natural-color; SfM, structure-from-motion. For details about dates of shoreline data used at specific locations within a region, refer to the shoreline data files available for download in the companion online data report (Snyder and Gibbs, 2019)]

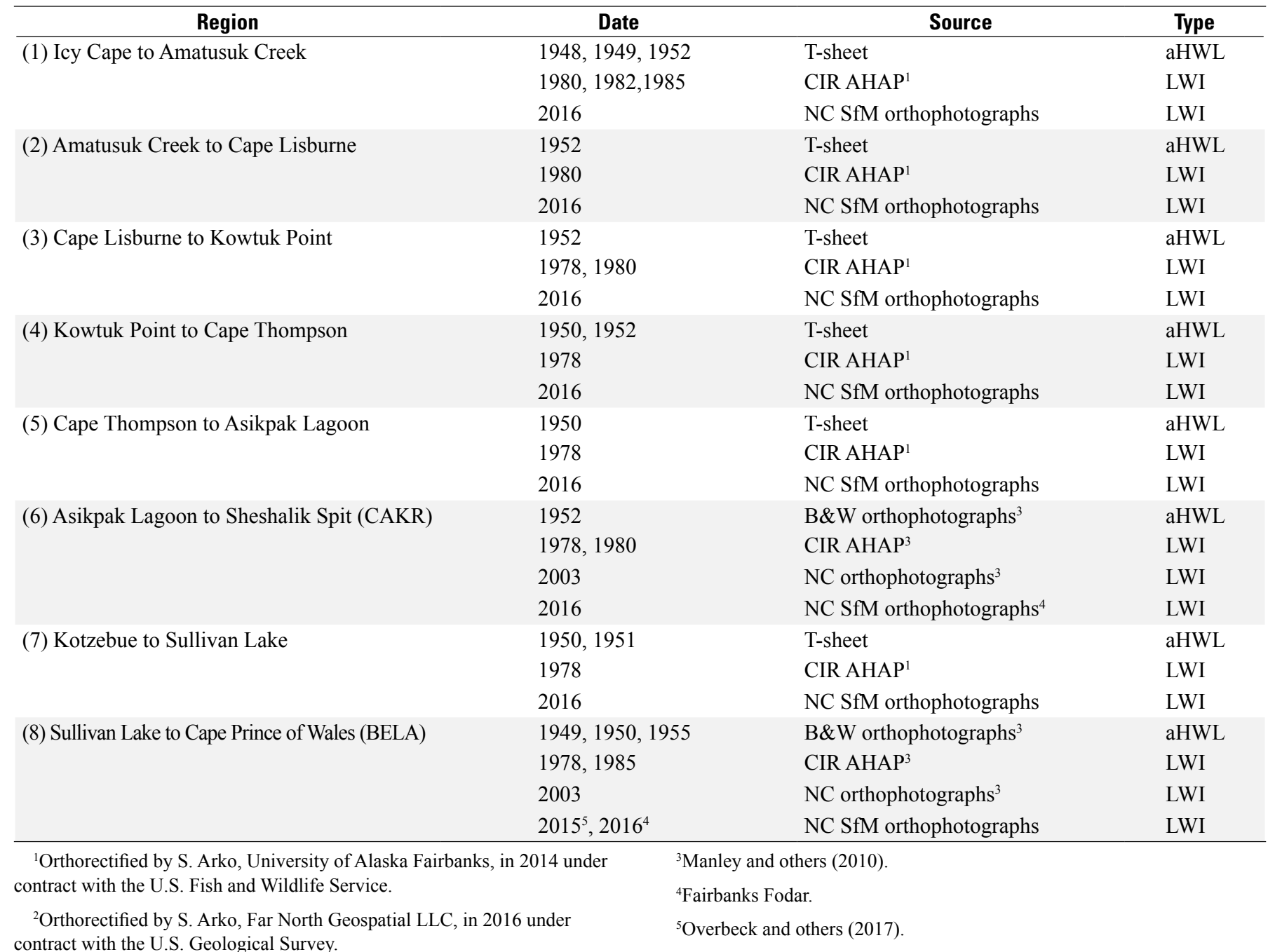

This report is part of a series of reports summarizing methods, results, and implications of the results in addition to maps illustrating rates of shoreline change. The format, style, and methods used in this report closely follow that developed by Hapke and others (2006, 2010). Rates of shoreline change are published in this report for the purpose of regional characterization of shoreline behavior through time. The shoreline change results and products prepared by the USGS are not intended for detailed site-specific analysis of shoreline movement, nor are they intended to replace any official sources of shoreline change information identified by local or State government agencies or other Federal entities for regulatory uses. Rates of shoreline change presented herein may differ from other published rates, and differences do not necessarily indicate that the other rates are inaccurate. Some discrepancies are expected, considering the many possible ways of determining shoreline positions and rates of change, and the inherent uncertainty in calculating these rates. Rates of shoreline change presented in this report represent shoreline movement under past conditions. The results are not intended for predicting future shoreline positions or future rates of shoreline change.
Individual measurement transects for the north coast of Alaska from Icy Cape to Cape Prince of Wales (Snyder and Gibbs, 2019), as well as other open-ocean shoreline regions along U.S. coastlines, can be viewed in the USGS Coastal Change Hazards Portal (https://marine.usgs.gov/coastalchangehazardsportal).

\section{0s-Era Shorelines}

Circa-1950s shorelines were delineated from two sources: 1948 to 1952 National Ocean Service (formerly U.S. Coast and Geodetic Survey) T-sheets from Icy Cape to Asikpak Lagoon and 1949 to 1955 black-and-white (grayscale) orthoimagery from Asikpak Lagoon to Cape Prince of Wales (Manley and others, 2007a, b, c; Manley and others, 2010; Manley and Lestak, 2012; tables 1, 2; fig. 4). Although T-sheet shorelines extend south of Cape Thompson to Spafarief Bay in southern Kotzebue Sound, as well as around Cape Prince of Wales, the 1950sera orthoimagery from Manley and others $(2007 \mathrm{a}, \mathrm{b}, \mathrm{c})$ was determined to be superior and was used to delineate shorelines south of Asikpak Lagoon. 


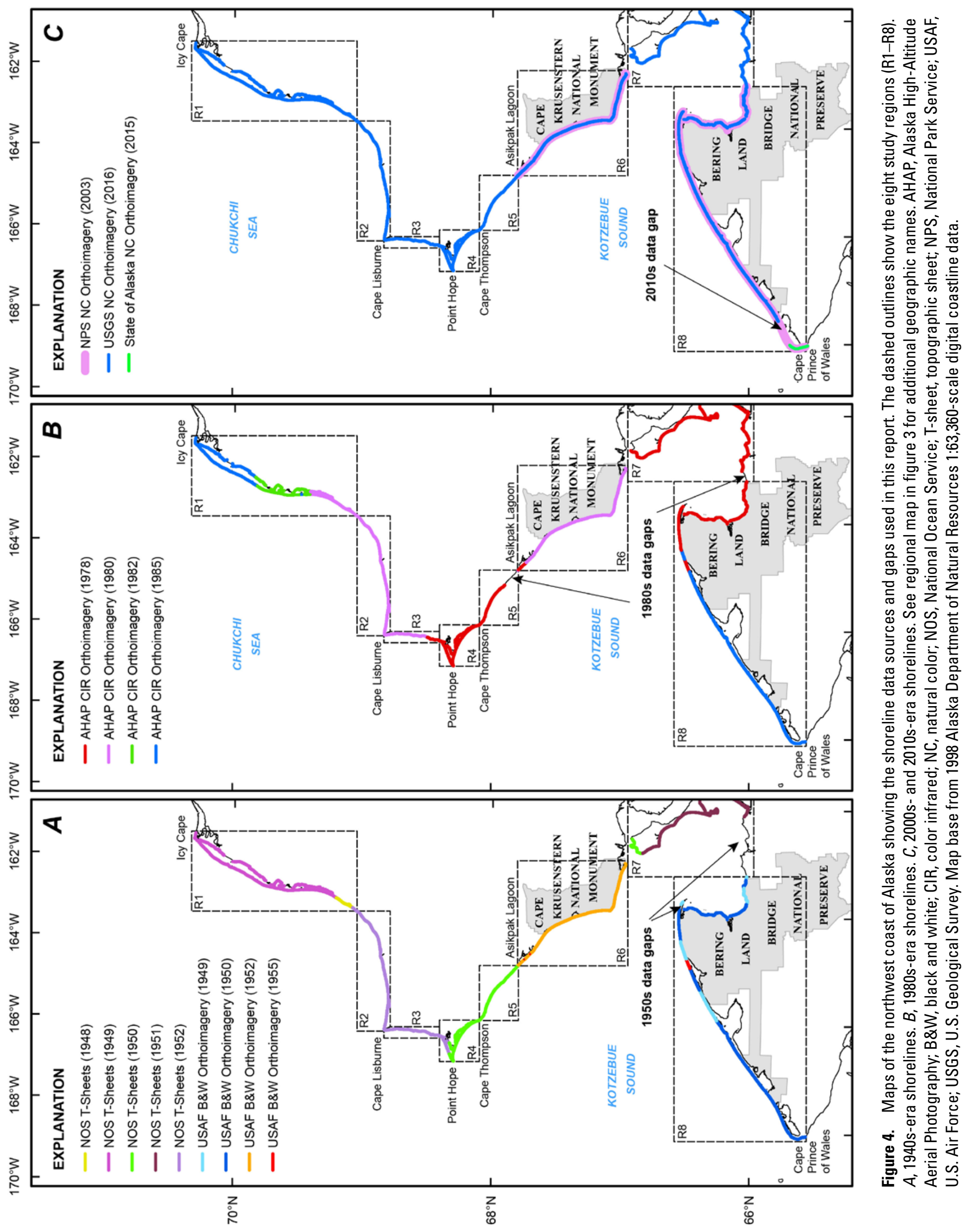




\section{0s T-sheets}

Previous researchers (Shalowitz, 1964; Crowell and others, 1991; Daniels and Huxford, 2001) who addressed the accuracy of T-sheets found that they meet National Map Accuracy Standards (Ellis, 1978) and recommended them for use in shoreline change studies as a valuable source of data needed to extend the time series of historical shoreline positions (National Research Council Committee on Coastal Erosion Zone Management, 1990). The 1950s-era T-sheets are highly detailed and include survey reference points, many of which are included in the National Geodetic Survey (NGS) benchmark database. Roads, buildings, lakes and drainage patterns, muddy and marsh areas, hills and ridges, cliffs, bluffs, mud deposits and shoal areas are consistently delineated on the maps. The original source of the T-sheets, as discussed in the "Descriptive Reports" associated with each sheet, is primarily from a combination of vertical and oblique aerial photography collected by the U.S. Navy and U.S. Coast and Geodetic Survey between August 1948 and July 1952.

In order to delineate accurate shoreline positions from the 1950s-era T-sheets, a number of modifications to the published T-sheet resources were required. Low-resolution (approximately 72 pixels per inch) georeferenced T-sheet raster scans, digitized vector shorelines, and descriptive reports that are available online (https://shoreline.noaa.gov/data/datasheets/t-sheets.html, accessed April 4, 2018) were determined to be incorrectly georeferenced, with offsets greater than 10-20 meters (m) compared to published NGS benchmark locations that were mapped on, and used as, survey control for the T-sheets, and analogous geomorphological features identifiable in other georeferenced image data sources used in this study as well as the Alaska's Statewide Digital Mapping Initiative (SDMI) SPOT5 satellite imagery. The offsets were for the most part spatially regular and possibly the result of a datum shifting error during the conversion from an analog to a digital resource. To resolve this registration error, higher resolution but non-georeferenced T-sheet raster scans (approximately 1,200 pixels per inch), were obtained from NOAA (http://nosimagery.noaa.gov/images/shoreline_surveys/ survey_scans/NOAA_Shoreline_Survey_Scans.html, accessed April 4, 2018) and georegistered to the low-resolution T-sheets using 4 or more graticule coordinates. An affine transformation was then applied to this georegistered, high-resolution raster based on one or more NGS benchmark coordinate tie-points that were also mapped on the corresponding T-sheet. Typically, only a single benchmark tie-point and affine shift was necessary to achieve improved and accurate georeferencing for an entire T-sheet. In some cases, additional tie-points obtained from the 1980s-era or 2016 imagery, SDMI SPOT5 satellite imagery, and (or) adjacent T-sheet graticules were required to properly georeference the raster images.

To verify T-sheets and datum transformations, a comparison was made between the georeferenced T-sheets, georeferenced 1980s-era and 2016 imagery, and published locations of the NGS benchmark locations. A problem unique to the north coast of Alaska, compared to the conterminous U.S. coast, is the relative paucity of temporally consistent, region-wide shoreline datasets and limited horizontal and vertical control with which to reference the geographic data. A poor geoid model and existing digital elevation model, lack of extensive infrastructure of roads, buildings, and so on, away from communities, and defense- and oil-and-gas-related development also makes it difficult to control imagery, accurately assess position errors, and (or) compare datasets from one time period to the next. For this study, lake shorelines, other geomorphic features, benchmark locations, and limited roads, building, or infrastructure were used to evaluate the relative consistency or accuracy of the T-sheets with the assumption that most of these features have not changed significantly through time. Although there was some disagreement with lake edges near the corner of the sheets and with increasing distance from the coast, for the most part, features in the datasets corresponded well and were within the uncertainty tolerance of the original scale, registration, and digitization process.

T-sheet shorelines were digitized on screen at a scale of $1: 1,500$ or better. The shoreline reference feature is the approximate mean high water line as mapped on the T-sheets. Uncertainty values related to the georeferencing and digitization are included in the uncertainty assessment described in table 3.

\section{0s Black and White Aerial Photography}

1950s-era shorelines from Lestak and others (2010) were delineated from orthorectified aerial photography derived from 1:43,000-scale, black and white (grayscale) photographs acquired by the U.S. Air Force from 1949 to 1955 using the protocol outlined by Manley and Lestak (2012) (fig. 4; Manley and others, 2007a; Manley and others, 2010). The images have a pixel resolution of $1.0 \mathrm{~m}$ and relative horizontal accuracy of $2.0 \mathrm{~m}$. Digital scans of the photographs were fully orthorectified in ERDAS IMAGINE using air-photograph camera models, a digital elevation model, information from calibration reports, and imageto-image control points linked to 2003 base imagery (described below). These images and the companion digital shoreline were completed as part of a study on coastal erosion in collaboration with the University of Colorado's Institute of Arctic and Alpine Research and the National Park Service's Arctic Network Inventory and Monitoring Program (http://instaar.colorado.edu/ QGISL/ARCN/, accessed April 11, 2018).

Shorelines were digitized on screen at a scale of 1:700. The shoreline reference feature is the instantaneous land-water interface (waterline). Shoreline error was calculated using the square root of the sum of the squares calculation of the orthorectification and digitization errors. Errors for the 1950s shorelines are $2.9 \mathrm{~m}$ for Bering Land Bridge National Preserve and $2.2 \mathrm{~m}$ for Cape Krusenstern National Monument. Shoreline and shoreline change data are available directly from Lestak and others (2010) but are included in this analysis as well as the full data release associated with this report (Snyder and Gibbs, 2019).

\section{0s-Era Shorelines}

1980s-era shorelines were delineated from 1:64,000-scale, color-infrared photographs acquired by the USGS and NOAA, as part of the AHAP program between 1978 and 1985 (fig. 4). 
Table 3. Measurement uncertainties associated with all datasets.

[-, not applicable; N/A, not available; AHAP, Alaska High-Altitude Aerial Photography; T-sheets, topographic sheets]

\begin{tabular}{|c|c|c|c|c|c|c|c|c|c|c|c|c|c|}
\hline $\begin{array}{l}\text { Measurement uncertainty } \\
\text { (meters) }\end{array}$ & 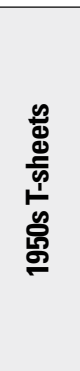 & 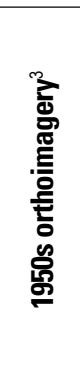 & 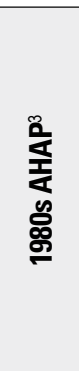 & 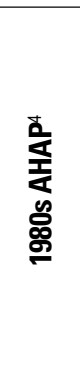 & 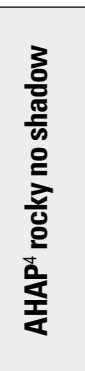 & 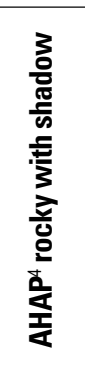 & 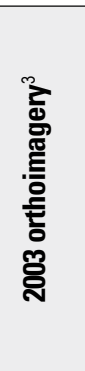 & 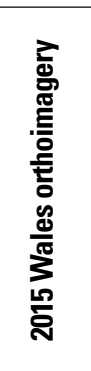 & 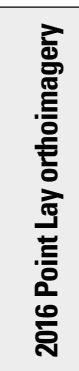 & 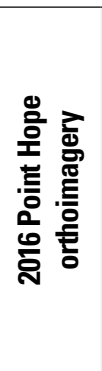 & 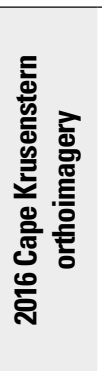 & 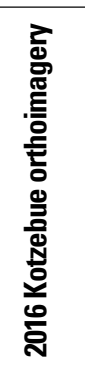 & 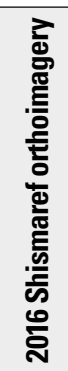 \\
\hline Georeferencing $\left(\mathrm{U}_{\mathrm{g}}\right)$ & 11 & 2 & 1.5 & 10 & 10 & 10 & 0 & 0.3 & 0.3 & 0.3 & 0.3 & 0.3 & 0.3 \\
\hline Digitizing $\left(\mathrm{U}_{\mathrm{d}}\right)$ & 5 & - & - & 3 & 10 & 20 & - & 2 & 2 & 2 & 2 & 2 & 2 \\
\hline $\begin{array}{l}\text { Bering Land Bridge National } \\
\text { Preserve }\end{array}$ & - & 2.1 & 2.3 & - & - & - & 1 & - & - & - & - & - & - \\
\hline $\begin{array}{l}\text { Cape Krusenstern National } \\
\text { Monument }\end{array}$ & - & 1.1 & 1.6 & - & - & - & 1.7 & - & - & - & - & - & - \\
\hline High water line ${ }^{1}\left(U_{p d}\right)$ & - & $\mathrm{N} / \mathrm{A}$ & $\mathrm{N} / \mathrm{A}$ & $\mathrm{N} / \mathrm{A}$ & - & - & -5.4 & -0.5 & -0.7 & -3.2 & 1.0 & -2.4 & -1.4 \\
\hline $\begin{array}{l}\text { Total shoreline position uncer- } \\
\text { tainty }^{2}\left(\mathrm{U}_{\mathrm{p}}\right)\end{array}$ & 15.7 & - & - & 10.4 & 14.1 & 22.4 & - & 2.1 & 2.1 & 3.8 & 2.2 & 3.1 & 2.5 \\
\hline $\begin{array}{l}\text { Bering Land Bridge National } \\
\text { Preserve total shoreline posi- } \\
\text { tion uncertainty }\end{array}$ & - & 2.9 & 2.7 & - & - & - & 1.0 & - & - & - & - & - & - \\
\hline $\begin{array}{l}\text { Cape Krusenstern National } \\
\text { Monument total shoreline } \\
\text { position uncertainty }\end{array}$ & - & 2.3 & 2.2 & - & - & - & 1.7 & - & - & - & - & - & - \\
\hline
\end{tabular}

For the coastal stretch between Icy Cape and Asikpak Lagoon (regions 1-5), shorelines were digitized from georeferenced AHAP photographs from 1980 and 1985 obtained from U.S. Fish and Wildlife Service's Arctic Landscape Conservation Cooperative (fig. 4). Digital image scans obtained from USGS Earth Explorer (http://earthexplorer.usgs.gov, accessed April 11, 2018) at a resolution of 1,015 pixels per inch were processed using structure-from-motion photogrammetric methods by the University of Alaska, Fairbanks' Alaska Satellite Facility and the Geographic Information Network of Alaska (by S. Arko, 2014, under contract with the U.S. Fish and Wildlife Service). Ground control was based on circa-2015 SDMI SPOT-5 satellite imagery and USGS Digital Orthophoto Quarter Quadrangles (DOQQs). The final images are high resolution (pixel size of approximately $1.6 \mathrm{~m}$ ) and have a horizontal accuracy that exceeds the National Map Accuracy Standard for 1:24,000-scale map products. This standard requires a circular error of 90 percent for a horizontal error of $12.5 \mathrm{~m}$. Utilizing ground control from the SDMI and the DOQQs, this standard was met throughout most of the area. This imagery is available as a web mapping service at http:/gina.alaska. edu/catalogs/7056-alaska-high-altitude-aerial-photography-ahap (accessed April 11, 2018). Shorelines were digitized on screen at a scale of 1:1,500. The shoreline reference feature is the instantaneous land-water interface except in low-lying, backbarrier lagoon mudflat environments, where an attempt was made to correspond with the shoreline reference feature mapped in the 1950s-era T-sheets and 2016 photography in order to avoid erroneous measurements of shoreline change. In some locations, particularly around steep rocky headlands and where shadows exist on the coast, a shoreline position could not be reasonably identified.

For the coastal stretch between Kotzebue and Sullivan Lake (region 7) shorelines were digitized from georeferenced AHAP photographs from 1978 (fig. 4). Digital image scans obtained from USGS Earth Explorer at a resolution of 1,015 pixels per inch were processed using structure-from-motion photogrammetric methods by Far North Geospatial, LCC (by S. Arko, 2016, under contract with the USGS). Ground control was based on circa-2015 SDMI SPOT-5 satellite imagery. The final images are high resolution (pixel size of approximately $1.6 \mathrm{~m}$ ) and have a horizontal accuracy that exceeds the National Map Accuracy Standard for 1:24,000-scale map products. This 
standard requires a circular error of 90 percent for a horizontal error of $12.5 \mathrm{~m}$. Utilizing ground control from the SDMI, this standard was met throughout most of the area. Shorelines were digitized on screen at a scale of 1:1,500. The shoreline reference feature is the instantaneous land-water interface. In some locations, particularly around steep rocky headlands and where shadows exist on the coast, a shoreline position could not be reasonably identified.

For the coastal stretch between Asikpak Lagoon and Sheshalik Spit (region 6) and Sullivan Lake and Cape Prince of Wales (region 8), digital shorelines were acquired from Lestak and others (2010). The shorelines were delineated from orthorectified AHAP image frames from 1978, 1980, and 1985 using protocols outlined by Manley and Lestak (2012) (fig. 4; Manley and others, 2007b; Manley and others, 2010). The images have a pixel resolution of $1.0 \mathrm{~m}$, a relative horizontal accuracy of $1.5 \mathrm{~m}$, and are superior in quality and accuracy compared to the AHAP imagery north of Asikpak Lagoon. Digital scans of the photographs were fully orthorectified in ERDAS IMAGINE using air-photograph camera models, a digital elevation model, information from calibration reports, and image-to-image control points linked to 2003 base imagery (described below). These images and the companion shoreline were completed as part of a study on coastal erosion in collaboration between the University of Colorado's Institute of Arctic and Alpine Research and the National Park Service's Arctic Network Inventory and Monitoring Program. Shorelines were digitized on screen at a scale of 1:700. The shoreline reference feature is the instantaneous land-water interface (waterline). Shoreline error was calculated using the square root of the sum of the squares of the orthorectification and digitization errors. Errors for the approximately 1980s-era shorelines are $2.2 \mathrm{~m}$ for region 6 (Cape Krusenstern National Monument) and $2.8 \mathrm{~m}$ for region 8 (Bering Land Bridge National Preserve). Shoreline and shoreline change data are available directly from Lestak and others (2010) but are also included in this analysis as well as the full data release associated with this report (Snyder and Gibbs, 2019).

\section{0s-Era Shorelines}

In regions 6 and 8, including the coastal areas of Bering Land Bridge National Preserve, Cape Krusenstern National Monument, and nearby parts of northwestern Alaska, digital shorelines were acquired from Lestak and others (2010). The shorelines were delineated from orthorectified photomosaics created by AeroMetric, Inc. (subsequently acquired by Quantum Spatial, Inc.) and derived from 1:24,000-scale, natural-color photographs acquired for the National Park Service on July 19, 2003, and for NOAA on September 14-24, 2003, using protocols outlined by Manley and Lestak (2012) (fig. 4; Manley and others, 2007c; Manley and others, 2010). The orthophotomosaics have a pixel resolution of $0.6 \mathrm{~m}$, and an absolute horizontal accuracy of $1.1 \mathrm{~m}$. These images and the companion shoreline were completed as part of a study on coastal erosion in collaboration between the University of Colorado's Institute of Arctic and Alpine Research and the National Park Service's Arctic Network Inventory and Monitoring
Program. Shoreline error was calculated using the square root of the sum of the squares of the orthorectification and digitization errors. Errors for the 2003 shorelines are $1.7 \mathrm{~m}$ for region 6 (Cape Krusenstern National Monument) and $1.0 \mathrm{~m}$ for region 8 (Bering Land Bridge National Preserve). Shoreline and shoreline change data are available directly from Lestak and others (2010) but are included in this analysis as well as the full data release associated with this report (Snyder and Gibbs, 2019).

\section{0s-Era Shorelines}

The most recent shoreline positions were delineated from high-resolution, natural-color aerial photographs collected between December 28 and 29, 2015 (Overbeck and others, 2017), and between August 29 and September 03, 2016 (fig. 4). Digital photographs were collected and processed by Fairbanks Fodar using structure-from-motion photogrammetric methods. Coincident digital elevation measurements were also derived from the photographs. Acquisition methods and hardware are fully described by Nolan and others (2015). The orthophotomosaics have a pixel resolution of $0.2 \mathrm{~m}$ and a horizontal accuracy of less than $0.3 \mathrm{~m}$. Shorelines were digitized on screen at a scale of 1:1,500 or better using the instantaneous land-water interface as the shoreline proxy. Uncertainties in shoreline position are very low and predominantly related to averaging between individual wave run-up patterns on the outer coast and on extensive mudflats present in back-barrier lagoon environments. In mudflat environments, the instantaneous land-water interface was not always used as the shoreline proxy; however, a best attempt was made to correspond to the shoreline feature used in the 1950s- and 1980s-era datasets to avoid erroneous measurements of shoreline change.

\section{Calculation and Interpretation of Shoreline Change Rates}

Rates of shoreline change were generated in ArcGIS using the Digital Shoreline Analysis System version 4.3, an ArcGIS extension developed by the USGS in cooperation with TPMC Environmental Services (Thieler and others, 2009). This tool allows the user to generate transects relative to a baseline that intersect the shorelines at a user-defined separation along the coast and calculate rates of change based on spatial and temporal differences between successive shorelines. For this analysis, baselines were constructed seaward of, and roughly parallel to, the general trend of the oldest shoreline. Using the Digital Shoreline Analysis System, transects were spaced at 50-m intervals and manually edited to assure they were as orthogonal to the most recent shorelines as possible and not overlapping. The analysis system employs the single-transect method to calculate change rates and rate uncertainties at regularly spaced transects (measurement locations) alongshore. The single-transect method uses various methods (for example, end point rate, linear regression rates, least squares, weighted least squares) to fit a trend 
line to the time series of historical shoreline positions at a transect. It is the most commonly utilized method for calculating shoreline change (for example, see Fletcher and others, 2003; Morton and others, 2004; Morton and Miller, 2005; Hapke and others, 2006; Hapke and Reid, 2007).

Rates of long-term ( $>60$ years) and short-term ( $<30$ years) shoreline change were calculated approximately every $50 \mathrm{~m}$ alongshore using the linear regression and end-point rate calculation methods included in the Digital Shoreline Analysis System. Long-term rates of shoreline change, in $\mathrm{m} / \mathrm{yr}$, were calculated at all locations using a linear regression rate calculation. Short-term rates of shoreline change, in $\mathrm{m} / \mathrm{yr}$, were calculated using an end-point rate calculation at locations where two shoreline positions were available (1980s and 2010s) and a linear regression rate calculation where three shorelines were present (1980s, 2000s, and 2010s).

There is no assumption that rates of shoreline change are linear between the survey years; the rate represents the net change between the surveys. Thus, rates of change represent averages and do not reflect the episodic nature of coastal change, particularly with regards to bluff retreat, which can cause substantial changes to the coastline in a short amount of time when meters-wide blocks of permafrost-bound sediment collapse from the bluffs.

Shoreline change rates and rate uncertainties at individual transect locations are available in the data release associated with this report (Snyder and Gibbs, 2019).

\section{Estimation of Shoreline Position Uncertainty}

Several sources of error affect the accuracy of historical shoreline positions and the uncertainties associated with the shoreline change rates calculated from them. Measurement uncertainties, including errors related to shoreline digitization, image resolution, image rectification, and T-sheet plotting, are related to analyst manipulation of the map and photograph products. For T-sheets, National Map Accuracy Standards (U.S. Bureau of the Budget, 1947) were adopted that provide a measure of both position and measurement uncertainties. For photographs, measurement uncertainty is related to the orthorectification process and onscreen delineation of the shoreline.

Anders and Byrnes (1991), Crowell and others (1991), Thieler and Danforth (1994), and Moore (2000) provided general estimates of the typical HWL measurement uncertainties associated with (1) mapping methods and materials for historical shorelines, (2) the registration of shoreline position relative to geographic coordinates, and (3) shoreline digitizing. Using methods by Crowell and others (1993) and further developed and applied by Hapke and others (2006, 2010), we identify four uncertainty terms for HWL-type shorelines: georeferencing uncertainty $\left(U_{\mathrm{g}}\right)$, digitizing uncertainty $\left(U_{\mathrm{d}}\right)$, T-sheet survey uncertainty $\left(U_{\mathrm{t}}\right)$, and aerial/satellite image uncertainty $\left(U_{\mathrm{a}}\right)$. The georeferencing uncertainty $\left(U_{\mathrm{g}}\right)$ represents the maximum acceptable root mean square error (RMSE) for T-sheets at a scale of 1:20,000 and is applied to historical shorelines derived from T-sheets only. In this study, the total RMSE was maintained below 0.0001 degrees, which is approximately $11 \mathrm{~m}$ at this latitude. Typically, the resulting RMSE was much lower than 0.0001 degrees. The digitizing uncertainty $\left(U_{\mathrm{d}}\right)$ is the uncertainty associated with digitizing the shoreline and was assumed to be equal to one-half the line width (typically about $10 \mathrm{~m}$ ) on the scanned T-sheets and two times the pixel resolution of the imagery. The maximum T-sheet survey uncertainty $\left(U_{t}\right)$, determined by Shalowitz (1964), incorporates all errors associated with the mapping process, including distance to rodded points, plane-table position, and identification of the HWL. The aerial image uncertainty $\left(U_{\mathrm{a}}\right)$ is the horizontal accuracy or RMSE of the orthorectification process of the image data. Values were provided by the data originators and are different for the individual datasets (table 3).

A fifth uncertainty term in our shoreline change analysis is the uncertainty in the position of the water line at the time of the survey $\left(U_{\mathrm{pd}}\right)$. Because ocean water levels fluctuate with daily tides and in response to changing winds, waves, and air pressure, a photograph can capture the shoreline at a range of water levels. The diurnal tidal range along the north coast of Alaska is $0.21 \mathrm{~m}$ at Prudhoe Bay and $0.27 \mathrm{~m}$ at Red Dog Dock tidal stations (NOAA, 2018a, b), however, water levels can become elevated or depressed as much as several meters because of winds and low-pressure systems. We assume these water-level offsets were accounted for during the T-sheet mapping efforts, as noted in the descriptive reports accompanying the surveys, by conducting concurrent water level surveys during image acquisition and mapping, and per standard mapping practices described by Shalowitz (1964). However, elevated or reduced absolute water levels during acquisition of the 1980s-, 2000s-, and 2010s-era datasets have the potential to significantly modify the horizontal position of the shoreline as determined from the land-water interface, especially in low-lying areas. In order to estimate the positional uncertainties associated with the land-water interface shoreline, we evaluated water level deviations from MHW measured at the Red Dog Dock tidal station, established August 21, 2003, for the dates of acquisition of the aerial photographs (NOAA, 2018b; table 4). No comprehensive information on regional beach slopes exists for the study area. However, based on limited field validation and the generally narrow width of beaches $(<50 \mathrm{~m})$, which are comprised primarily of gravel and coarse sand, a slope of 1:20 (5 percent or approximately 3 degrees) was chosen as a conservative estimate of beach slope for the entire study area. The average water level deviation from MHW for each dataset was multiplied by the assumed slope (1:20) to determine the estimated uncertainty of the land-water interface digitized water-line position relative to $\mathrm{MHW}$ at the time of the survey $\left(U_{\mathrm{pd}}\right)$. This average horizontal position uncertainty ranges between -5.4 and $+1.0 \mathrm{~m}$ (table 4 ).

For each shoreline position, the total uncertainty is found as the square root of the sum of squares of the relevant uncertainty terms, based on an assumption that each term is random and independent of the others (Taylor, 1997). For shorelines derived for this study, the total shoreline position uncertainty $\left(U_{\mathrm{p}}\right)$ at each transect $i$, is calculated following the method developed by Hapke and others $(2006,2010)$ :

$$
U_{\mathrm{p}_{i}}=\sqrt{U_{\mathrm{g}_{i}}^{2}+U_{\mathrm{d}_{i}}^{2}+U_{\mathrm{t}_{i}}^{2}+U_{\mathrm{a}_{i}}^{2}+U_{\mathrm{pd}_{i}}^{2}}
$$


Table 4. Daily water level deviation from mean high water measured at the Red Dog Dock tidal station and calculated change in shoreline position.

[BELA, Bering Land Bridge National Preserve; CAKR, Cape Krusenstern National Monument; GMT, Greenwich Mean Time; MHW, Mean High Water; Max, maximum; Min, minimum]

\begin{tabular}{|c|c|c|c|c|c|c|c|c|}
\hline \multirow[t]{2}{*}{ Data source } & \multicolumn{2}{|c|}{ Acquisition date and time (GMT) } & \multicolumn{3}{|c|}{$\begin{array}{c}\text { Water level deviation from } \\
\text { MHW (meters) }\end{array}$} & \multicolumn{3}{|c|}{ Horizontal change $^{1}$ (meters) } \\
\hline & Start & End & Max & Min & Mean & Max & Min & Mean \\
\hline \multicolumn{9}{|c|}{2003 orthophotographs } \\
\hline BELA, CAKR & 19-Sept. & 19-Sept. & -0.11 & -0.45 & -0.27 & -2.2 & -9.0 & -5.4 \\
\hline \multicolumn{9}{|c|}{2015 orthophotographs } \\
\hline \multicolumn{9}{|c|}{2016 orthophotographs } \\
\hline Point Hope & 29-Aug. 18:44:31 & 30-Aug. 04:08:45 & 0.07 & -0.31 & -0.16 & 1.3 & -6.2 & -3.2 \\
\hline Cape Krusenstern & 30-Aug. 16:55:39 & 30-Aug. 23:05:55 & 0.12 & -0.06 & 0.05 & 2.3 & -1.3 & 1.0 \\
\hline Shishmaref & 31-Aug. 15:47:02 & 01-Sept. 03:21:20 & 0.08 & -0.21 & -0.07 & 1.5 & -4.3 & -1.4 \\
\hline
\end{tabular}

${ }^{1}$ Horizontal change determined by multiplying the water level deviation by an assumed beach slope of 1:20.

Individual uncertainty terms in equation 1 are defined in table 3. Shoreline position uncertainties are included in the digital shoreline data files associated with this report (Snyder and Gibbs, 2019). Measurement and total shoreline position uncertainties for all datasets used in this updated analysis are listed in table 3, as determined by equation 1 .

\section{Estimation of Shoreline Change Rate Uncertainty at Individual Transects}

The uncertainty of a single transect's end-point shoreline change rate, $U_{\mathrm{R}_{\mathrm{h}}}$, is found as the quadrature sum of the uncertainties for each year's shoreline position, divided by the number of years between the shoreline surveys:

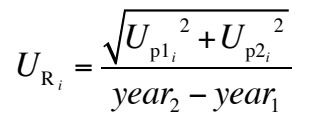

where $U_{\mathrm{p} 1_{i}}$ and $U_{\mathrm{p} 2_{i}}$ are the shoreline position uncertainties of the first $\left(\right.$ year $\left._{1}\right)$ and second $\left(\right.$ year $\left._{2}\right)$ shorelines, respectively, at transect $i$, determined in equation (1) (after Hapke and others, 2006).

For the linear regression method, the uncertainty of a single transect's shoreline change rate, $U_{\mathrm{R}_{i}}$, is the 90 -percent confidence interval on the linear regression slope. Shoreline change rate uncertainties are included in the transect data files associated with this report (Snyder and Gibbs, 2019).

\section{Estimation of Regionally Averaged Shoreline Change Rate Uncertainty}

In addition to shoreline change rates and rate uncertainties at individual transects, this report provides regionally averaged rates and the associated uncertainties as an indication of broader spatial trends (table 5).

Following the approach of Ruggiero and others (2013), the procedure for finding the uncertainty associated with regionally averaged shoreline change rates, $\bar{U}_{\mathrm{Rq}^{*}}$, described below, is the same for both the end-point and linear regression methods. We estimate that each transect rate uncertainty is partially independent of the others. To estimate the regionally averaged uncertainty of partially independent transect rates, we first evaluated the effective number of independent uncertainty values, $n^{*}$. Following Garrett and Toulany (1981), we found $n^{*}$ on the basis of the spatially lagged autocorrelation of each measure of shoreline change rate uncertainty. Assuming the uncertainty of a region can be represented by $\bar{U}_{\mathrm{R}}$, we found the uncertainty of a regionally averaged change rate to be:

$$
\bar{U}_{\mathrm{Rq} *}=\frac{1}{\sqrt{n^{*}}} \times \bar{U}_{\mathrm{R}}
$$

In all regions, this method resulted in a large reduction in the original sample size, $n$, shown in table 5 . The reduced effective sample size $\left(n^{*}\right)$ was also determined for combined regions and shoreline types by summing the $n^{*}$ values within each region. Average uncertainty values found using equation 3 , reported in table 5, are generally much smaller than the arithmetic mean confidence interval. 
Table 5. Summary of average shoreline change rates, average rate uncertainties, and percentage of transects eroding for the study area and each region relative to shoreline type.

[Uncertainty numbers in bold are average rates where confidence interval values are less than the average rate value, indicating the rates are statistically significant; CAKR, Cape Krusenstern National Monument; BELA, Bering Land Bridge National Preserve; LT, long-term rates, 1950s to 2010s; ST, short-term rates, 1980s to 2010s; m/yr, meters per year; m, meters; -, not calculated]

\begin{tabular}{|c|c|c|c|c|c|c|c|c|c|c|}
\hline \multirow[b]{2}{*}{ Shoreline type } & \multirow{2}{*}{$\begin{array}{l}\text { Number } \\
\text { of } \\
\text { transects } \\
(n)\end{array}$} & \multirow{2}{*}{$\begin{array}{c}\text { Average } \\
\text { of rates } \\
\text { (m/yr) }\end{array}$} & \multirow{2}{*}{$\begin{array}{l}\text { Standard } \\
\text { deviation }\end{array}$} & \multirow{2}{*}{$\begin{array}{c}\text { Average } \\
\text { uncertainty } \\
\text { (m/yr) }\end{array}$} & \multirow{2}{*}{$\begin{array}{c}\text { Independent } \\
n\left(n^{*}\right)\end{array}$} & \multirow{2}{*}{$\begin{array}{c}\text { Uncertainty } \\
\text { reduced for } \\
\text { independent } n \\
\text { (m/yr) }\end{array}$} & \multicolumn{2}{|c|}{ Maximum rate (m/yr) } & \multicolumn{2}{|c|}{$\begin{array}{c}\text { Percentage of } \\
\text { transects eroding }\end{array}$} \\
\hline & & & & & & & Erosion & Accretion & Total & $\begin{array}{c}\text { More } \\
\text { than } 1 \\
\mathrm{~m} / \mathrm{yr}\end{array}$ \\
\hline All shorelines, LT & 24,129 & -0.2 & 0.7 & 0.9 & 842 & 0.1 & -8.3 & 9.6 & 68 & 9 \\
\hline All shorelines, ST & 25,411 & -0.2 & 0.9 & 0.3 & - & - & -16.0 & 20.0 & 63 & 9 \\
\hline Sheltered, LT & 3,589 & -0.1 & 0.4 & 0.7 & 274 & 0.1 & -4.1 & 2.4 & 58 & 2 \\
\hline Sheltered, ST & 3,603 & -0.1 & 0.4 & 0.3 & - & - & -5.2 & 1.6 & 60 & 3 \\
\hline Mainland, LT & 12,179 & -0.2 & 0.4 & 0.7 & 98 & 0.1 & -4.1 & 2.1 & 68 & 3 \\
\hline Mainland, ST & 13,023 & -0.2 & 0.5 & 0.3 & - & - & -5.6 & 1.6 & 63 & 4 \\
\hline Sheltered mainland, ST & 3,418 & -0.1 & 0.4 & 0.3 & - & - & -5.2 & 1.5 & 61 & 3 \\
\hline Exposed barrier, LT & 11,769 & -0.3 & 0.9 & 1.2 & 86 & 0.1 & -8.3 & 9.6 & 69 & 15 \\
\hline Exposed barrier, ST & 11,783 & -0.2 & 1.2 & 0.2 & - & - & -16.0 & 20.0 & 64 & 14 \\
\hline Sheltered barrier, LT & 181 & 0.1 & 0.5 & 1.0 & 15 & 0.3 & -0.7 & 2.4 & 49 & 0 \\
\hline Sheltered barrier, ST & 185 & 0.0 & 0.4 & 0.3 & - & - & -1.5 & 1.6 & 54 & 2 \\
\hline \multicolumn{11}{|c|}{ Region 1: Icy Cape to Amatusuk Creek } \\
\hline All shorelines, LT & 5,733 & -0.1 & 0.9 & 1.5 & 242 & 0.1 & -6.8 & 9.6 & 58 & 9 \\
\hline All shorelines, ST & 5,774 & -0.1 & 1.3 & 0.3 & - & - & -12.9 & 20.0 & 57 & 9 \\
\hline Exposed, LT & 3,211 & -0.1 & 1.2 & 2.0 & 75 & 0.2 & -6.8 & 9.6 & 58 & 14 \\
\hline Exposed, ST & 3,241 & 0.0 & 1.7 & 0.3 & - & - & -12.9 & 20.0 & 55 & 12 \\
\hline All shorelines, ST & 2,427 & -0.2 & 0.4 & 0.4 & - & - & -1.8 & 1.1 & 70 & 3 \\
\hline Exposed, LT & 2,217 & -0.3 & 0.3 & 0.9 & 25 & 0.2 & -1.9 & 0.3 & 90 & 6 \\
\hline Exposed, ST & 2,218 & -0.2 & 0.4 & 0.4 & - & - & -1.8 & 1.1 & 74 & 4 \\
\hline Sheltered, LT & 209 & 0.0 & 0.1 & 0.4 & 58 & 0.1 & -0.4 & 0.5 & 46 & 0 \\
\hline Sheltered, ST & 209 & 0.0 & 0.1 & 0.3 & - & - & -0.2 & 0.7 & 35 & 0 \\
\hline \multicolumn{11}{|c|}{ Region 3: Cape Lisburne to Kowtuk Point } \\
\hline Exposed, LT & 999 & 0.0 & 0.2 & 0.6 & 178 & 0.1 & -0.7 & 1.1 & 45 & 0 \\
\hline Exposed, ST & 999 & 0.1 & 0.2 & 0.4 & - & - & -0.8 & 1.1 & 32 & 0 \\
\hline \multicolumn{11}{|c|}{ Region 4: Kowtuk Point to Cape Thompson (Point Hope) } \\
\hline All shorelines, LT & 2,246 & -0.1 & 0.5 & 1.0 & 120 & 0.1 & -4.1 & 2.1 & 61 & 3 \\
\hline All shorelines, ST & 2,249 & -0.1 & 0.7 & 0.3 & - & - & -9.1 & 5.6 & 62 & 3 \\
\hline Exposed, LT & 1,388 & -0.1 & 0.6 & 1.2 & 71 & 0.1 & -4.1 & 2.1 & 63 & 5 \\
\hline Exposed, ST & 1,388 & -0.1 & 0.8 & 0.3 & - & - & -9.1 & 5.6 & 57 & 4 \\
\hline Sheltered, LT & 858 & -0.1 & 0.3 & 0.6 & 49 & 0.1 & -1.4 & 2.1 & 59 & 0 \\
\hline
\end{tabular}


Table 5.-Continued

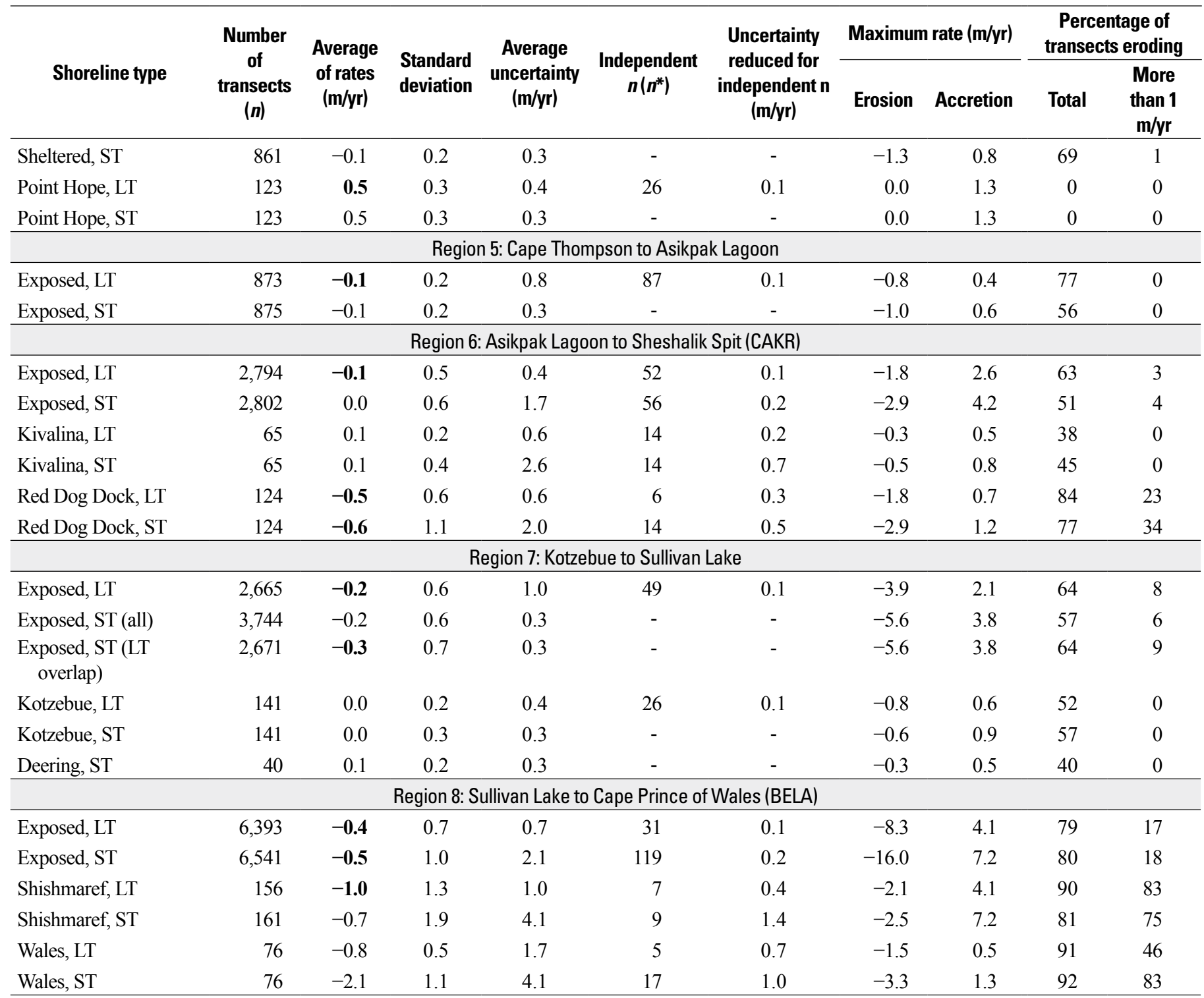

\section{Results from Analysis of Historical Shoreline Change}

For the presentation of shoreline change rates, the north coast of Alaska between Icy Cape and Cape Prince of Wales was subdivided into eight regions (fig. 3), which are based broadly on similarities in coastal geomorphology, orientation of the coast, and data availability. Regionally averaged rates of long-term shoreline change and the associated average values of rate uncertainty are presented in table 5. Maximum erosion and accretion rates for individual regions are reported in table 6 . Nearly all region-averaged long-term rates are statistically significant in this analysis.

In contrast to other NASC studies that evaluated only openocean sandy shorelines and coastal cliffs, this report presents rates for both exposed open-ocean and sheltered mainland shorelines.
We define exposed open-ocean shorelines to include mainland coast, barrier beaches, islands, and spits that are exposed directly to open-ocean wave, wind, and sea-ice conditions. Sheltered shorelines include any mainland shoreline and bay or rivermouth bars and spits that are sheltered from open-ocean conditions by offshore barrier islands, beaches, or spits. Sheltered shorelines were identified in regions $1,2,4,6$, and 8 , however, shoreline change rates were not calculated in regions 6 and 8 because of a lack of shoreline data from Lestak and others (2010). No distinction was made between a sand or gravel beach versus a coastal bluff with no fronting beach - the shoreline mapped was the land-water interface whether it was a beach or the base of a bluff or cliff.

Sections of rocky coast were visually identified in all but region 1 using the 2015 and 2016 imagery and confirmed by ShoreZone coastal classification mapping oblique video and photography (http://www.shorezone.org/, accessed July 15, 2019). 
Table 6. Long- and short-term maximum shoreline change rates by region.

[Long-term rates reported here were calculated using the linear regression method. Short-term rates reported here were calculated using the end-point method, except for regions 6 and 8, where short-term rates were calculated using the linear regression method. Max., maximum; $\mathrm{m}$, meters, $\mathrm{m} / \mathrm{yr}$, meters per year]

\begin{tabular}{|c|c|c|c|c|c|c|c|c|}
\hline & $\begin{array}{l}\text { Long-term } \\
\text { rate }(\mathrm{m} / \mathrm{yr})\end{array}$ & $\pm(\mathrm{m} / \mathrm{yr})$ & $\begin{array}{l}\text { Net shoreline } \\
\text { movement (m) }\end{array}$ & Location & $\begin{array}{l}\text { Short-term } \\
\text { rate }(\mathrm{m} / \mathrm{yr})\end{array}$ & $\pm(\mathrm{m} / \mathrm{yr})$ & $\begin{array}{c}\text { Net shoreline } \\
\text { movement } \\
\text { (m) }\end{array}$ & Location \\
\hline \multicolumn{9}{|c|}{ Region 1: Icy Cape to Amatusuk Creek } \\
\hline Max. accretion & 9.6 & 1.8 & 641.2 & Utukok Pass & 20.0 & 0.3 & 722.5 & $\begin{array}{l}\text { South of Naokok } \\
\text { Pass }\end{array}$ \\
\hline Max. accretion & 0.5 & 0.4 & 29.2 & West end of Agiak Lagoon & 1.1 & 0.3 & 39.2 & $\begin{array}{c}\text { Between Igrarok } \\
\text { and Ayugatak } \\
\text { Creeks }\end{array}$ \\
\hline \multicolumn{9}{|c|}{ Region 3: Cape Lisburne to Kowtuk Point } \\
\hline \multicolumn{9}{|c|}{ Region 4: Kowtuk Point to Cape Thompson (Point Hope) } \\
\hline Max. erosion & -4.1 & 22.1 & -252.5 & Point Hope & -9.1 & 0.3 & -347.0 & $\begin{array}{l}\text { Point Hope (north } \\
\text { side) }\end{array}$ \\
\hline Max. accretion & 2.1 & 0.4 & 143.0 & Barrier fronting Kukpuk River & 5.6 & 0.3 & 212.5 & $\begin{array}{l}\text { Point Hope (south } \\
\text { side) }\end{array}$ \\
\hline \multicolumn{9}{|c|}{ Region 5: Cape Thompson to Asikpak Lagoon } \\
\hline Max. erosion & -0.8 & 0.2 & -53.4 & $\begin{array}{l}\text { Barrier fronting Singoalik } \\
\text { Lagoon }\end{array}$ & -1.0 & 0.3 & -37.0 & $\begin{array}{c}\text { Barrier fronting } \\
\text { Mapsorak } \\
\text { Lagoon }\end{array}$ \\
\hline Max. accretion & 0.4 & 0.1 & 28.6 & $\begin{array}{l}\text { Barrier fronting Mapsorak } \\
\text { Lagoon }\end{array}$ & 0.6 & 0.3 & 23.0 & $\begin{array}{l}\text { West of } \\
\text { Amaktusak } \\
\text { Creek }\end{array}$ \\
\hline Max. erosion & -3.9 & 7.3 & -244.7 & East of Cape Blossom & -5.6 & 0.3 & 215.0 & $\begin{array}{c}\text { East of Cape } \\
\text { Blossom }\end{array}$ \\
\hline Max. accretion & 2.1 & 3.7 & 139.0 & Kiwalik & 3.8 & 0.3 & 145.4 & Kiwalik \\
\hline \multicolumn{9}{|c|}{ Region 8: Sullivan Lake to Cape Prince of Wales (BELA) } \\
\hline Max. erosion & -8.3 & 10.6 & -590.4 & $\begin{array}{l}\text { Inlet between Singeak and } \\
\text { Kividlo }\end{array}$ & -16.0 & 17.8 & 631.5 & $\begin{array}{l}\text { Inlet between } \\
\text { Singeak and } \\
\text { Kividlo }\end{array}$ \\
\hline Max. accretion & 4.1 & 2.6 & 298.4 & $\begin{array}{l}\text { Northeast end of Sarichef } \\
\text { Island (Shishmaref) }\end{array}$ & 7.2 & 5.1 & 227.0 & $\begin{array}{l}\text { Northeast end of } \\
\text { Sarichef Island } \\
\text { (Shishmaref) }\end{array}$ \\
\hline
\end{tabular}

In these areas, shoreline change rates on individual transects are near the analytical uncertainty, except where large rockfalls have occurred, and do not significantly change the regionally averaged shoreline change rates.

Each section below describes the geographical extent of the region, including any special features, population centers, coastal development, or U.S. Department of Defense Distant Early Warning (DEW) site-related infrastructure, followed by a brief summary of coastal geomorphology including representative aerial photographs, and finally, a summary of shoreline types and change rates for the region as a whole and for subregions within are provided.

Geospatial data (Snyder and Gibbs, 2019) associated with this Open-File Report are available online at https://doi. org/10.5066/P9H1S1PV and the USGS Coastal Change Hazards Portal at https://marine.usgs.gov/coastalchangehazardsportal/. 


\section{Region 1: Icy Cape to Amatusuk Creek}

The coast of region 1 extends approximately $160 \mathrm{~km}$ southwest along the Chukchi Sea coast from Icy Cape to just west of Amatusuk Creek (fig. 5). The community of Point Lay, with a population of 287 in 2018 (State of Alaska, 2019), is the only population center and infrastructure development along this stretch of coast. A DEW site at Icy Cape was closed and abandoned in 1963. Clean up and remediation was completed in the early 2000 s and a gravel runway and building footings remain today. DEW and North Warning System (NWS) radar stations at Point Lay were deactivated in 1989 and 1994, respectively. Remediation work was completed by 2005 and a gravel airstrip and building pads remain.

This region includes both exposed open-ocean and sheltered coasts. The coastal reach is dominated by an extended chain of low-lying ( $<3 \mathrm{~m}$ high) barrier islands and spits that front the wide ( $<7 \mathrm{~km}$ wide) Kasegaluk Lagoon. The islands are generally narrow $(<500 \mathrm{~m})$ but have extensive intertidal back-barrier mudflats, especially around Akunik Pass and south of Naokok Pass (fig. 5). The coastal plain narrows toward the south before pinching out near Amatusuk Creek, where the Arctic Foothills meet the coast (fig. 2). Shoreline change rates were calculated
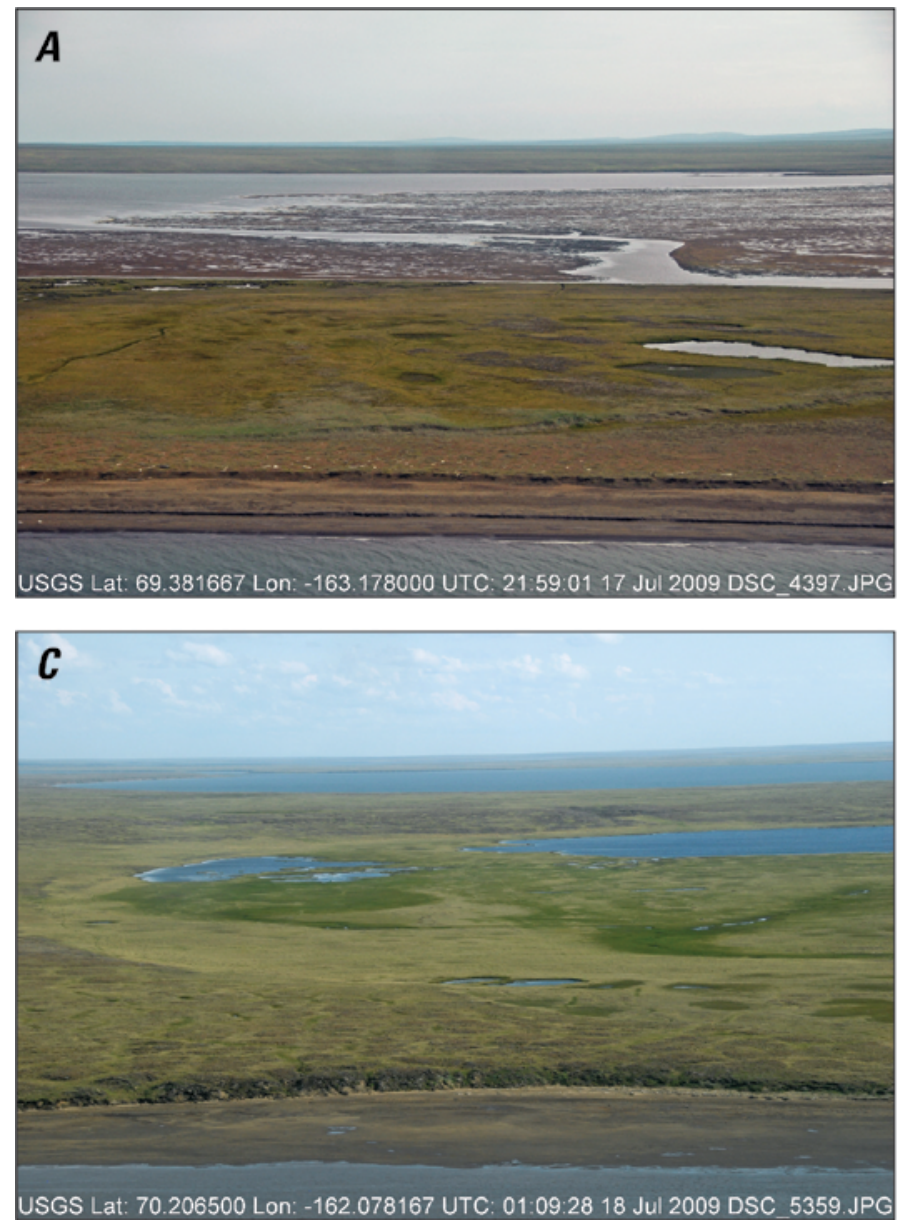

for both exposed open-ocean and sheltered shorelines. Sheltered shoreline types include mainland, barrier beach, and barrier spit. Exposed shoreline types include mainland, barrier beach, barrier island, and barrier spit (fig. 6).

Shoreline change rates for region 1 were determined using 1948, 1949, and 1952 T-sheets; 1980, 1982, and 1985 AHAP photography; and 2016 aerial photography (table 2, fig. 4). The region was slightly erosional over both the long and short term (58 and 57 percent of transects, respectively). Rates of change were generally low, but highly variable, with significantly higher rates of both erosion and accretion ( $>5 \mathrm{~m} / \mathrm{yr}$ ) associated with formation and northerly migration of inlets on the barrier island coast and breaching and erosion of thermokarst lakes on the mainland coast. Combined regional shoreline change rates for both the exposed and sheltered shorelines average $-0.1 \pm 0.1 \mathrm{~m} / \mathrm{yr}$ (ranging from -6.8 to $+9.6 \mathrm{~m} / \mathrm{yr}$ ) over the long term and $-0.1 \pm 0.3 \mathrm{~m} / \mathrm{yr}$ (ranging from -12.9 to $+20.0 \mathrm{~m} / \mathrm{yr}$ ) over the short term (fig. 7 , table 5 ). The regional shoreline change rates for exposed shorelines (mainland and barrier-island, -spit, and -beach coasts) are not significantly different than sheltered shorelines (table 5). The highest longand short-term erosion rates were measured on the north side of Akunik Pass. The highest long-term accumulation rates were
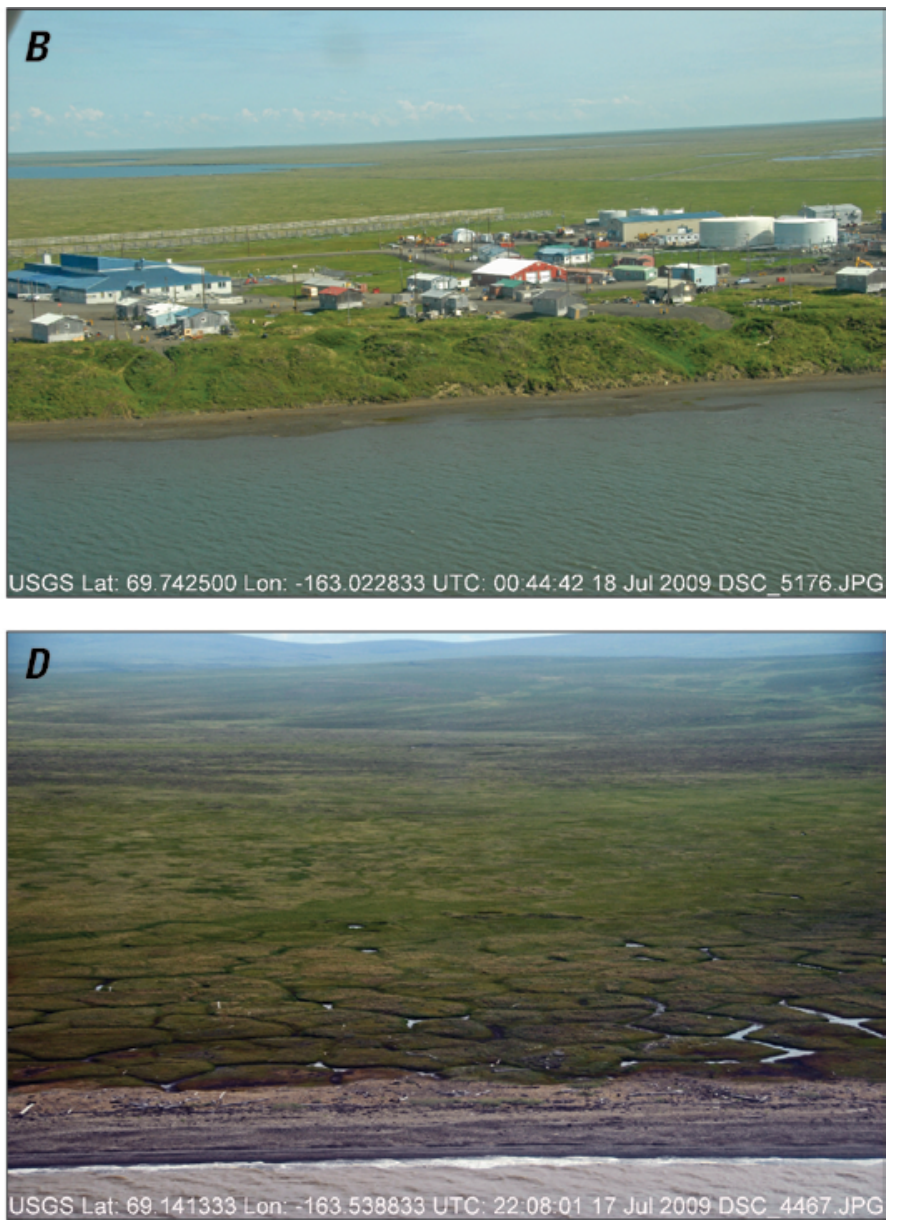

Figure 5. Aerial photographs showing examples of the coast in region 1. A, An extensive intertidal mudflat is exposed in Kasegaluk Lagoon behind a wide, vegetated, barrier island. The low-lying coastal plain is in the distance. $B$, The community of Point Lay sits atop low, vegetated, permafrost bluffs on the sheltered mainland coast. $C$, Exposed mudflats, visible in the foreground, front permafrost bluffs along the sheltered mainland coast of Kasegaluk Lagoon near Icy Cape. $D$, The coastal plain begins to narrow and increase in elevation toward the southern end of region 1. Photographs from Gibbs and Richmond, 2010. 
measured on the south side of Utukok Pass. The highest short-term accretion rates were measured on the north side of the pass south of Naokok Pass (fig. 7, table 6).

At Point Lay, mean shoreline change rates are $-0.4 \pm 0.2$ $\mathrm{m} / \mathrm{yr}$ (ranging from -1.7 to $+1.1 \mathrm{~m} / \mathrm{yr}$ ) and $-0.6 \pm 0.3 \mathrm{~m} / \mathrm{yr}$ (ranging from -1.8 to $+1.3 \mathrm{~m} / \mathrm{yr}$ ) for the long and short term, respectively. The mean net shoreline movement over the study period was $-26 \mathrm{~m}$, with a maximum of $115 \mathrm{~m}$ of erosion south of the airstrip and maximum accretion of $73 \mathrm{~m}$ to the north of the airstrip (fig. 8).

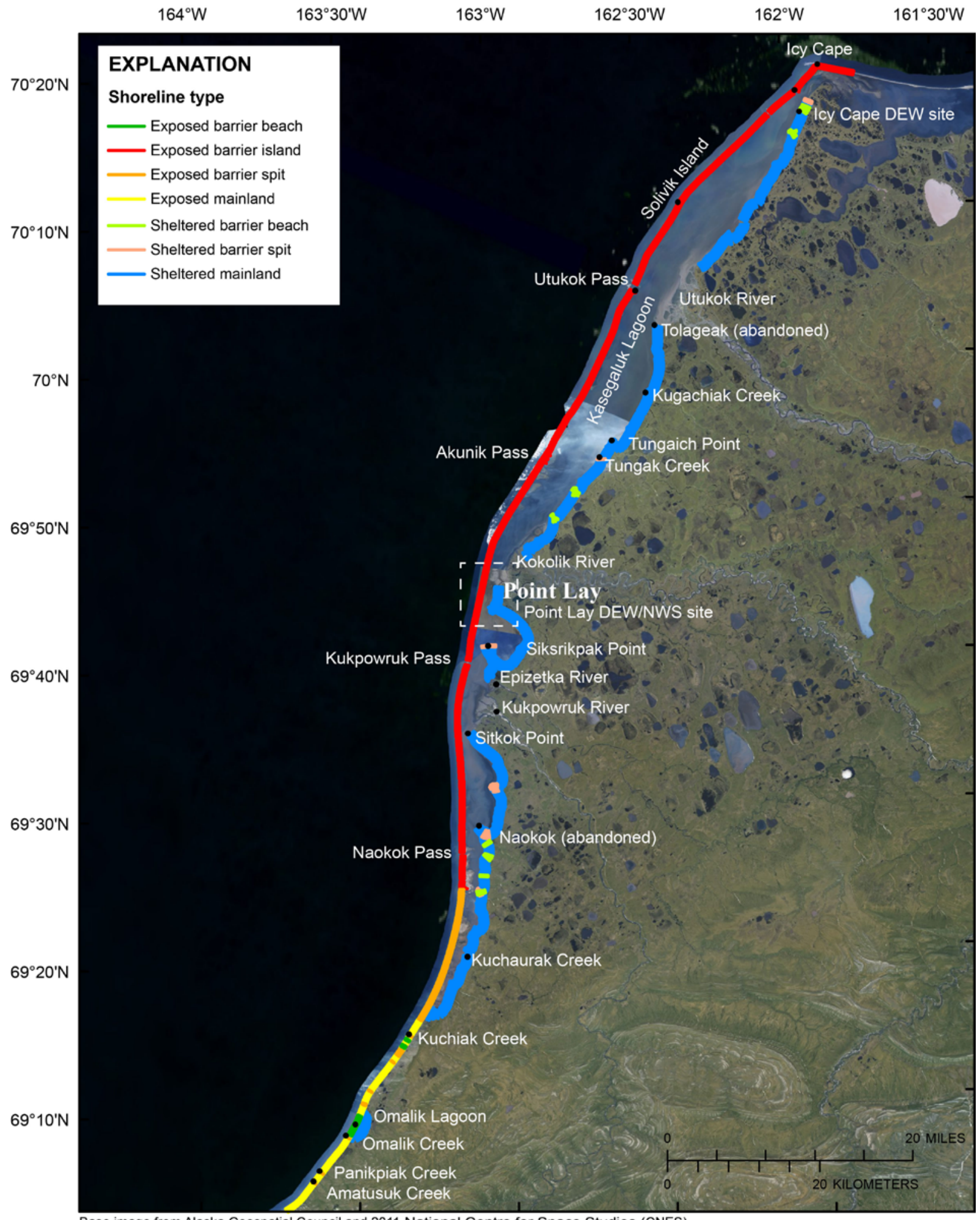

Base image from Alaska Geospatial Council and 2011 National Centre for Space Studies (CNES)

Figure 6. Map showing color-coded shoreline types in region 1 (Icy Cape to Amatusuk Creek). Dashed white outline shows the approximate location of figure 8. DEW, Distant Early Warning; NWS, North Warning System. 


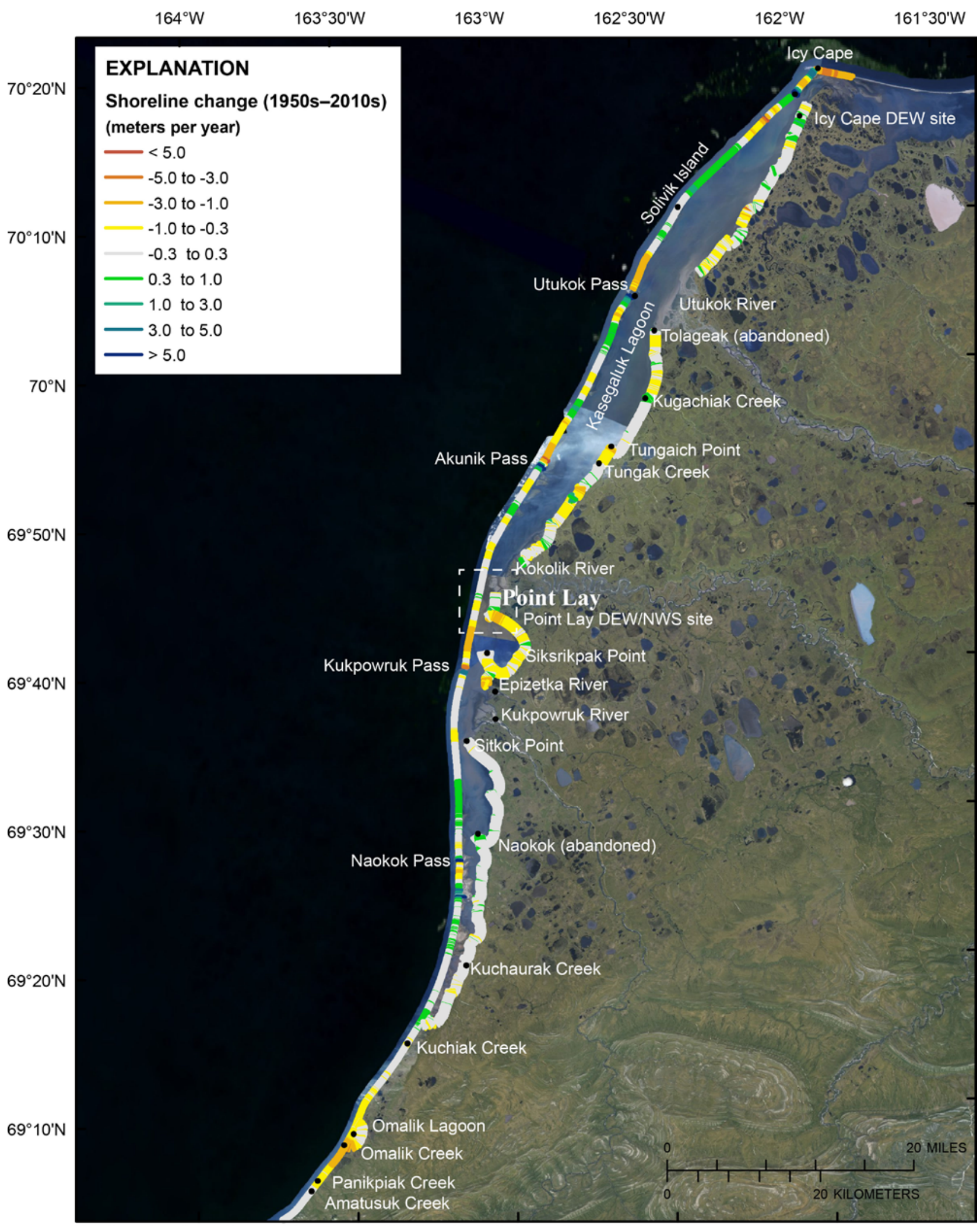

Base image from Alaska Geospatial Council and 2011 National Centre for Space Studies (CNES)

Figure 7. Map showing color-coded shoreline change rates in region 1 (Icy Cape to Amatusuk Creek) between 1947 and 2016. Dashed white outline shows the approximate location of figure 8. DEW, Distant Early Warning; NWS, North Warning System. 


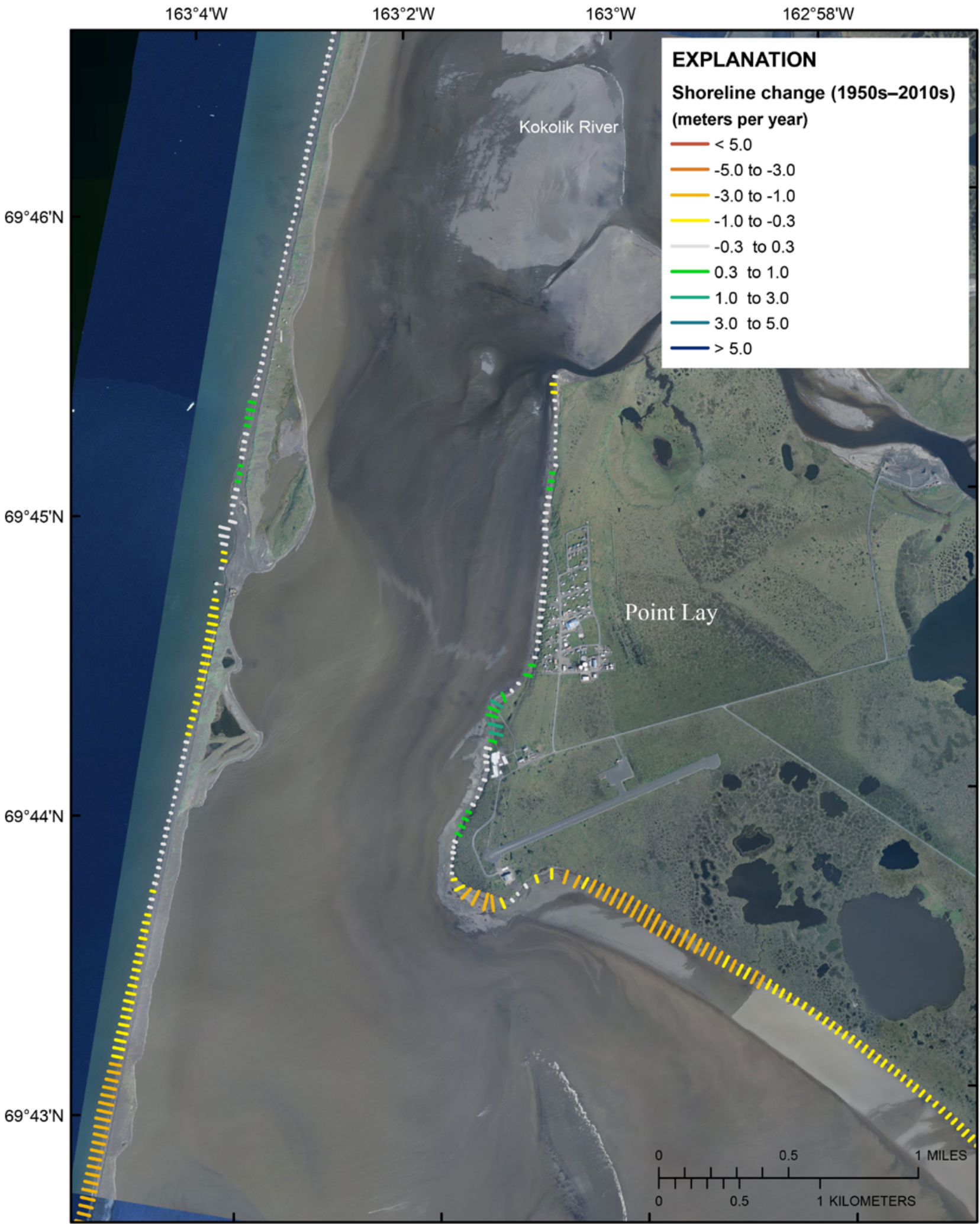

Base image from Alaska Geospatial Council and 2011 National Centre for Space Studies (CNES)

Figure 8. Map showing color-coded shoreline change rates near the community of Point Lay. The length of the colored lines represents the total distance of shoreline change between 1947 and 2016. 


\section{Region 2: Amatusuk Creek to Cape Lisburne}

Region 2 extends approximately $110 \mathrm{~km}$ southwest along the Chukchi Sea coast from Amatusuk Creek near Cape Beaufort to

Cape Lisburne. Infrastructure and development along this section of coast is limited to the former Cape Sabine DEW site near Cape Beaufort, and the former DEW and the currently active Cape Lisburne Air Force Station and Long Range Radar Site. The Cape Sabine Intermediate DEW site was closed and abandoned in 1963. Clean up and remediation was completed in the early 2000s and a gravel runway and building footings remain at the site. The Cape Lisburne DEW site closed in 1983 but the long range radar site remains active as part of the Alaska North American Aerospace Defense Command (NORAD) region under the jurisdiction of the 611th Air and Space Operations Center, Elmendorf Air Force Base, Alaska.

This region is characterized by a steep upland coast fronted discontinuously by narrow $(<30 \mathrm{~m})$ sand and gravel beaches and areas with wider coastal plain dissected by stream valleys $(<1.5 \mathrm{~km})$. Wider $(<100 \mathrm{~m})$ barrier beaches and spits front several small to moderate sized lagoons (Agiak, Ayugatak, and Igrarok) and restricted barrier spits and beaches are found at the mouth of many smaller streams. The upland coast is predominantly poorly consolidated permafrost bluffs with

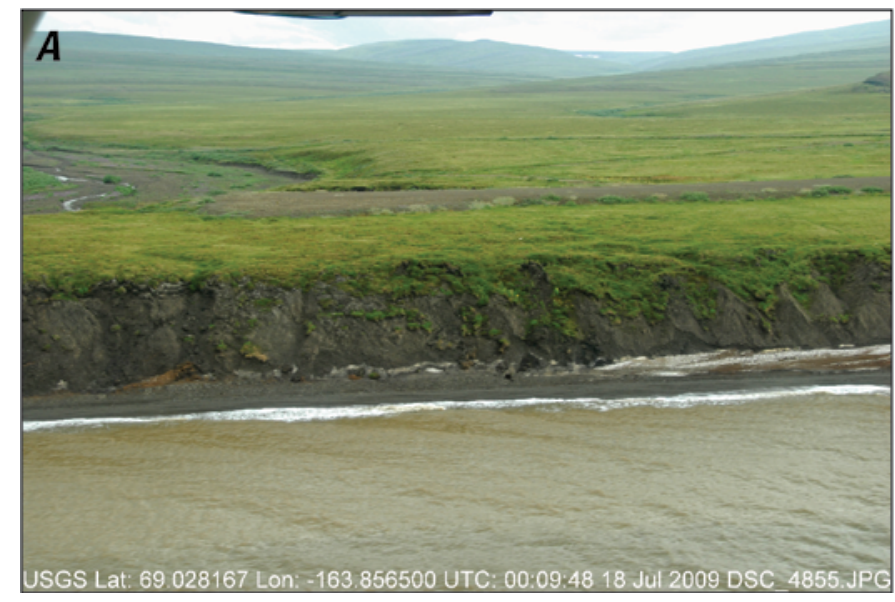

Figure 9. Aerial photographs showing examples of the coast in region 2. $A, A$ gravel airstrip is visible atop the $~ 12-m e t e r-h i g h$ permafrost bluffs at the former Cape Sabine Distant Early Warning radar site. B, A retrogressive thaw slump near Cape Beaufort; the alongshore length of this feature is about 145 meters. Photographs from Gibbs and Richmond, 2010.

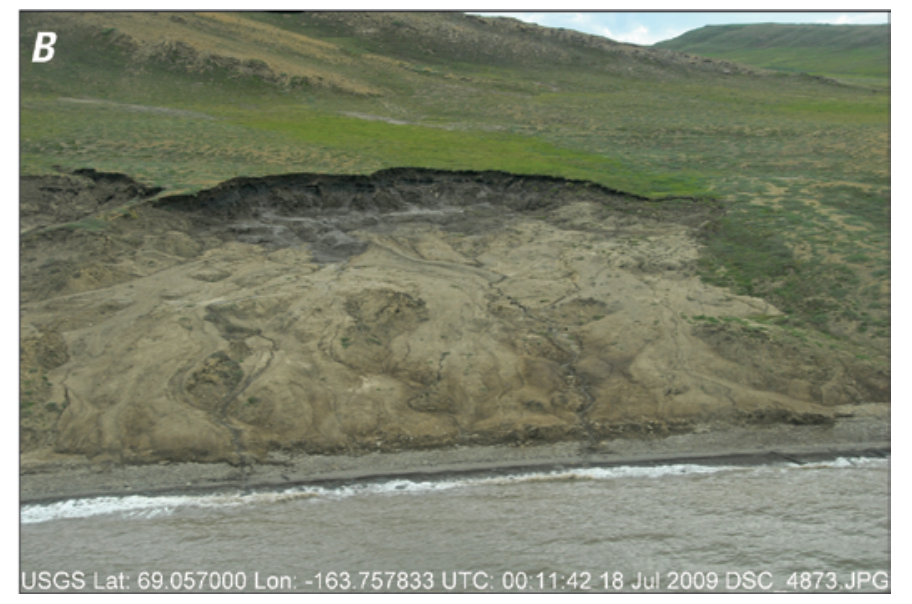
near-vertical, likely more indurated rocky cliffs west to Cape Lisburne (fig. 9). Shoreline change rates were calculated for both exposed open-ocean and sheltered shorelines. Shoreline types include sheltered mainland and exposed mainland, rocky mainland, barrier beach, and barrier spit (fig. 10).

Shoreline change rates for region 2 were determined using 1952 T-sheets, 1980 AHAP photography, and 2016 aerial photography (table 2, fig. 4). The region was erosional over both the short and long term (70 and 86 percent of transects, respectively). Rates of change were generally low along this reach of coast, and near the limit of analytical uncertainty, except on the sandy beaches and spits near streams and the wider barrier beaches. Regional shoreline change rates averaged $-0.3 \pm 0.1 \mathrm{~m} / \mathrm{yr}$ (ranging from -1.9 to $+0.5 \mathrm{~m} / \mathrm{yr}$ ) over the long term and $-0.2 \pm 0.4$ $\mathrm{m} / \mathrm{yr}$ (ranging from -1.8 to $+1.1 \mathrm{~m} / \mathrm{yr}$ ) over the short term (fig. 11, table 5). The highest long-term erosion rates were measured on the retreating barrier beach fronting Ayugatak Lagoon and highest short-term erosion rates were measured on the barrier spits fronting Ayugatak Creek and Pitmegea River near Cape Sabine. The highest long-term accretion rates, which are near the analytical uncertainty, were measured at the west end of Agiak Lagoon and the highest short-term accretion rates were measured on the mainland coast between Igrarok and Ayugatak Creeks (fig. 11, table 6). retrogressive thaw slumps common east of Thetis Creek, and 


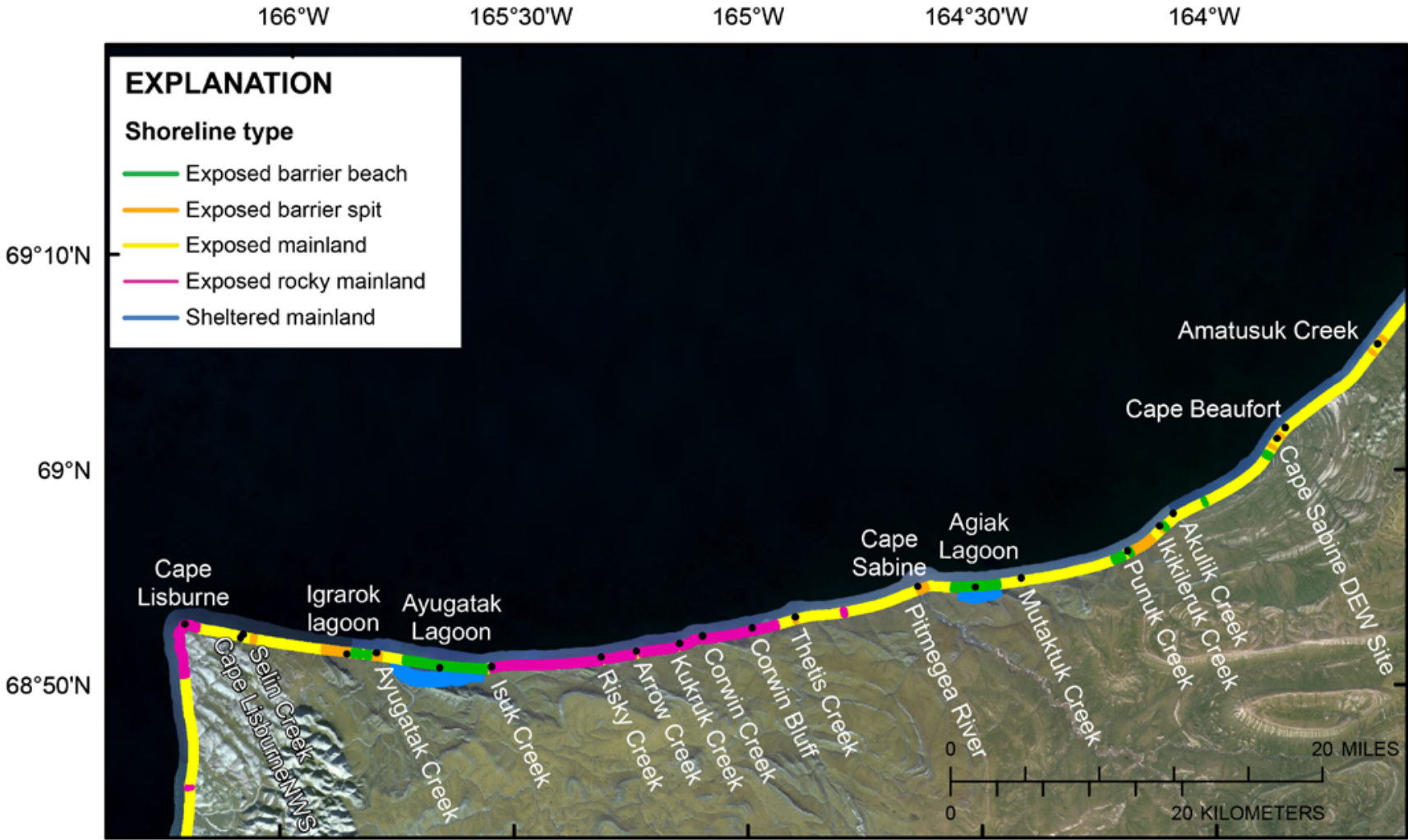

Base image from Alaska Geospatial Council and 2011 National Centre for Space Studies (CNES)

Figure 10. Map showing color-coded shoreline types in region 2 (Amatusuk Creek to Cape Lisburne). DEW, Distant Early Warning; NWS, North Warning System.

$166^{\circ} \mathrm{W}$

$165^{\circ} 30^{\prime} \mathrm{W}$

$165^{\circ} \mathrm{W}$

$164^{\circ} 30^{\prime} \mathrm{W}$

$164^{\circ} \mathrm{W}$

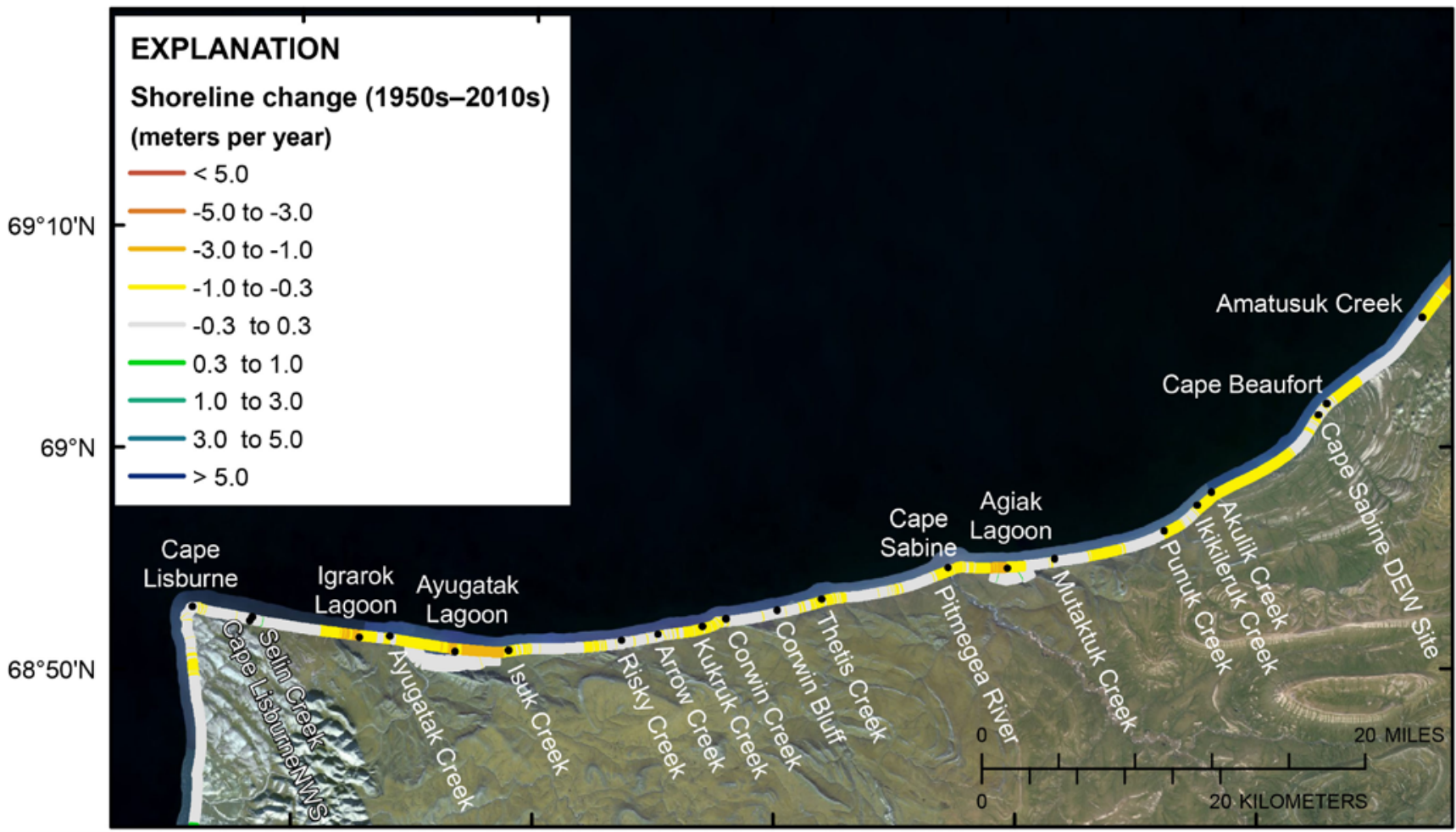

Base image from Alaska Geospatial Council and 2011 National Centre for Space Studies (CNES

Figure 11. Map showing color-coded shoreline change rates in region 2 (Amatusuk Creek to Cape Lisburne) between 1950 and 2016. DEW, Distant Early Warning; NWS, North Warning System. 


\section{Region 3: Cape Lisburne to Kowtuk Point}

Region 3 extends approximately $50 \mathrm{~km}$ south along the Chukchi Sea coast from Cape Lisburne to Kowtuk Point. There is no development or built infrastructure along this stretch of coast. This mainly north-south trending coastal reach is steep and rocky and few stream valleys reach the coast. Relatively wide $(>50 \mathrm{~m})$ sand and gravel beaches are persistent along the coast except around large rocky headlands and debris deposits. Low lying barrier spits are common but intermittent where streams reach the coast (fig. 12). This region includes only open-ocean exposed coastline and shoreline types include exposed mainland, rocky mainland, barrier beach, and barrier spit (fig. 13).

Shoreline change rates for the region were determined using 1952 T-sheets, 1978 and 1980 AHAP photography, and 2016 aerial photography (table 2, fig. 4). The region was slightly accretional over both the short and long term (55 and 68 percent of transects, respectively). Rates of change are generally low along this reach of coast and below the limit of analytical uncertainty, except where erosion was large or where rockfalls or landslides occurred. Regional shoreline change rates averaged $0.0 \pm 0.1 \mathrm{~m} / \mathrm{yr}$ (raning from -0.7 to $+1.1 \mathrm{~m} / \mathrm{yr}$ ) over the long term and $0.1 \pm 0.1 \mathrm{~m} / \mathrm{yr}$ (ranging from -0.8 to $+1.1 \mathrm{~m} / \mathrm{yr}$ ) over the short term (fig. 14, table 5). The highest erosion rates over both the long (less than $-0.5 \mathrm{~m} / \mathrm{yr}$ ) and short term (less than $-0.7 \mathrm{~m} / \mathrm{yr}$ ) were measured on a beach located between Kay Creek and Niak Creek just south of Cape Lisburne and on the barrier spit fronting Akalolik Creek (long term) and Kapaloak Creek (short term). The highest accretion rates over both the long and short term $(<1.1 \mathrm{~m} / \mathrm{yr})$ were associated with landslides and rockfalls located between Angolik Creek and Sigrikpak Creek (fig. 14, table 6).
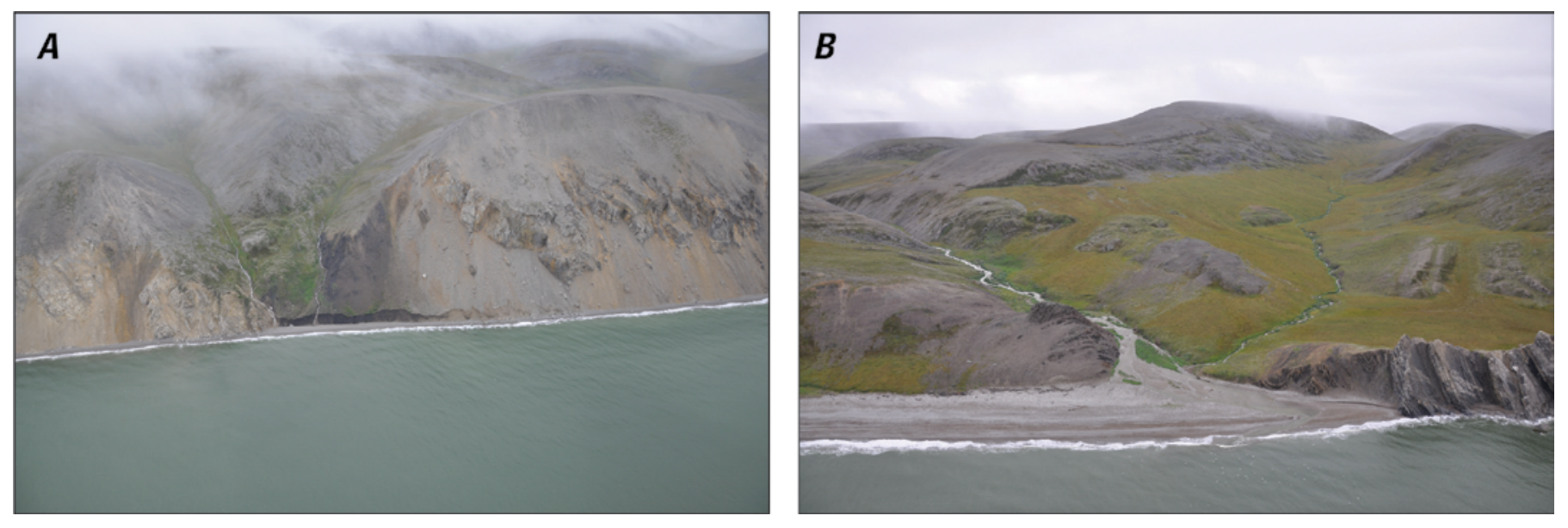

Figure 12. Aerial photographs showing examples of the coast in region 3. A, A narrow beach fronts the steep and rocky coast near Cape Lisburne. $B$, Niak Creek is one of many small stream valleys along this rocky stretch of coast. Alaska ShoreZone Program (https:// shorezone.org) photographs taken in August 2012 (licensed under Creative Commons 3.0; http://creativecommons.org/licenses/by/3.0//). 


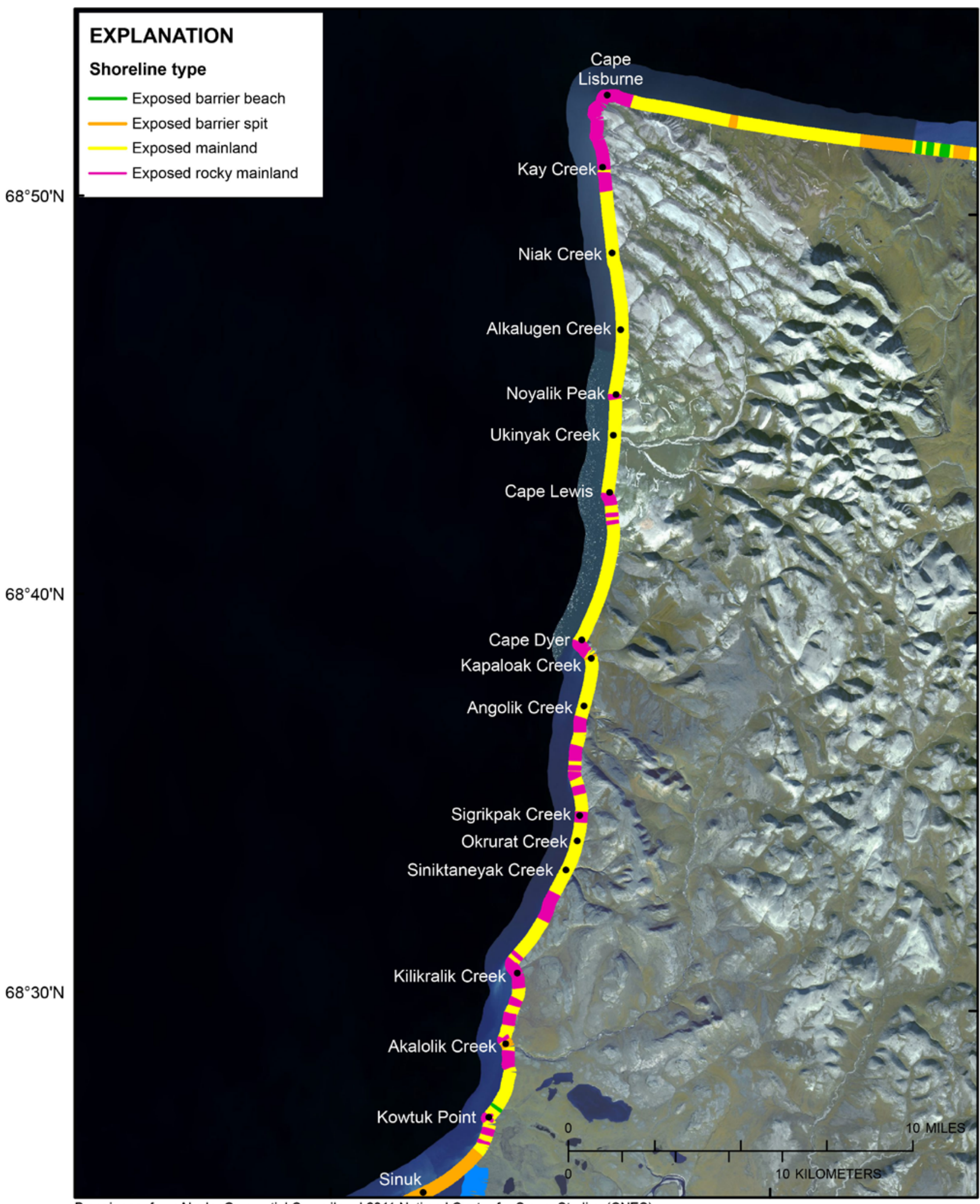

Base image from Alaska Geospatial Council and 2011 National Centre for Space Studies (CNES)

Figure 13. Map showing color-coded shoreline types in region 3 (Cape Lisburne to Kowtuk Point). 
$166^{\circ} 30^{\prime} \mathrm{W}$ $166^{\circ} \mathrm{W}$

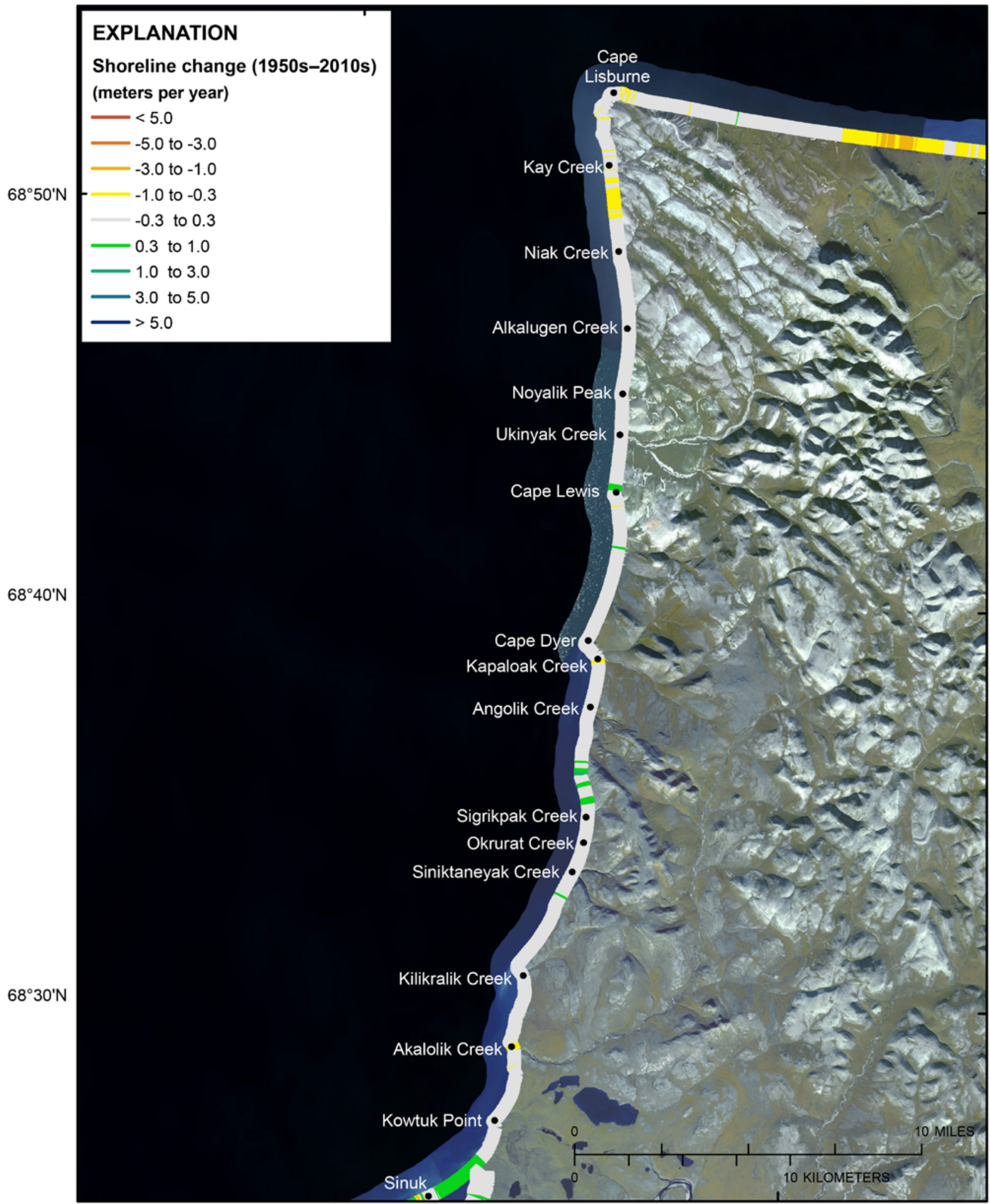

Base image from Alaska Geospatial Council and 2011 National Centre for Space Studies (CNES)

Figure 14. Map showing color-coded shoreline change rates in region 3 (Cape Lisburne to Kowtuk Point) between 1950 and 2016. 


\section{Region 4: Kowtuk Point to Cape Thompson (Point Hope)}

The coast of region 4 comprises the low-lying cuspate foreland of Point Hope and extends approximately $70 \mathrm{~km}$ south along the Chukchi Sea coast from Kowtuk Point to Cape Thompson. Point Hope is the westernmost point on the North American continent north of Kotzebue Sound. The community of Point Hope, with a population of 749 in 2018 (State of Alaska, 2019), is the only population center and infrastructure development along this stretch of coast.

Region 4 is characterized by extensive low-lying barrier beaches and spits fronting wide lagoons and small lakes. A welldeveloped beach-ridge complex is present at Point Hope (fig. 15). Shoreline types in this region include sheltered mainland, exposed mainland, rocky mainland, barrier beach, and barrier spit (fig. 16).

Shoreline change rates were calculated for both exposed open-ocean and sheltered shorelines using 1950 and 1952 T-sheets, 1978 AHAP photography, and 2016 aerial photography (table 2, fig. 4). The region was on average slightly erosional over both the long and short term along exposed (63 and 57 percent of transects, respectively) and sheltered (59 and 69 percent of transects, respectively) coastlines (table 5). Rates of change were generally low but highly variable along this reach of coast.
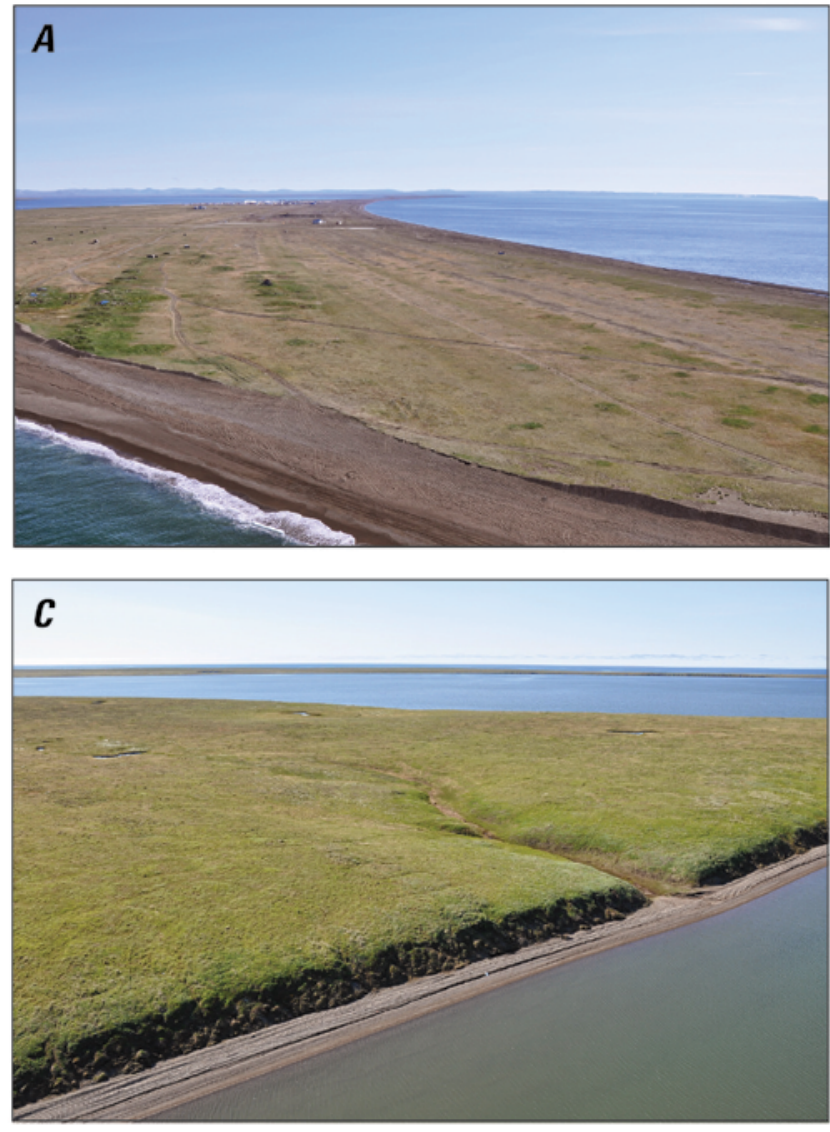

Regional shoreline change rates on the exposed coast averaged $-0.1 \pm 0.1 \mathrm{~m} / \mathrm{yr}$ (ranging from -4.1 to $+2.1 \mathrm{~m} / \mathrm{yr}$ ) over the long term and $-0.1 \pm 0.3 \mathrm{~m} / \mathrm{yr}$ (ranging from -9.1 to $+5.6 \mathrm{~m} / \mathrm{yr}$ ) over the short term (fig. 17, table 5). Regional shoreline change rates on the sheltered coast averaged $-0.1 \pm 0.1 \mathrm{~m} / \mathrm{yr}$ (ranging from -1.4 to $+2.1 \mathrm{~m} / \mathrm{yr}$ ) over the long term and $-0.1 \pm 0.3 \mathrm{~m} / \mathrm{yr}$ (ranging from -1.3 to $+0.8 \mathrm{~m} / \mathrm{yr}$ ) over the short term (fig. 17, table 5). The highest erosion rates over both the long (less than $-3 \mathrm{~m} / \mathrm{yr}$ ) and short term (less than $-5 \mathrm{~m} / \mathrm{yr}$ ) were measured at the northwest tip of Point Hope, with over $250 \mathrm{~m}$ of land loss since 1950. The highest accretion rates over the long term $(>1.5 \mathrm{~m} / \mathrm{yr})$ were measured at the southwesterly migrating inlet near Sinuk at the mouth of the Kukpuk River and on the prograding delta at Nalakachak Creek. The highest short-term accretion rates $(>3 \mathrm{~m} / \mathrm{yr})$ were measured along the southwest tip of Point Hope, with slightly lower accretion rates $(>2 \mathrm{~m} / \mathrm{yr})$ measured on the west side of the inlet near Sinuk and at Nalakachak Creek (table 6).

Adjacent to the community of Point Hope, mean shoreline change rates were relatively stable to slightly accretional, averaging $0.5 \pm 0.1 \mathrm{~m} / \mathrm{yr}$ (ranging from 0.0 to $+1.3 \mathrm{~m} / \mathrm{yr}$ ) and $0.5 \pm 0.3 \mathrm{~m} / \mathrm{yr}$ (ranging from 0.0 to $+1.3 \mathrm{~m} / \mathrm{yr}$ ) for the long and short term, respectively. The mean net shoreline movement over the study period was $+18 \mathrm{~m}$, with a maximum $88 \mathrm{~m}$ of accretion (fig. 18).
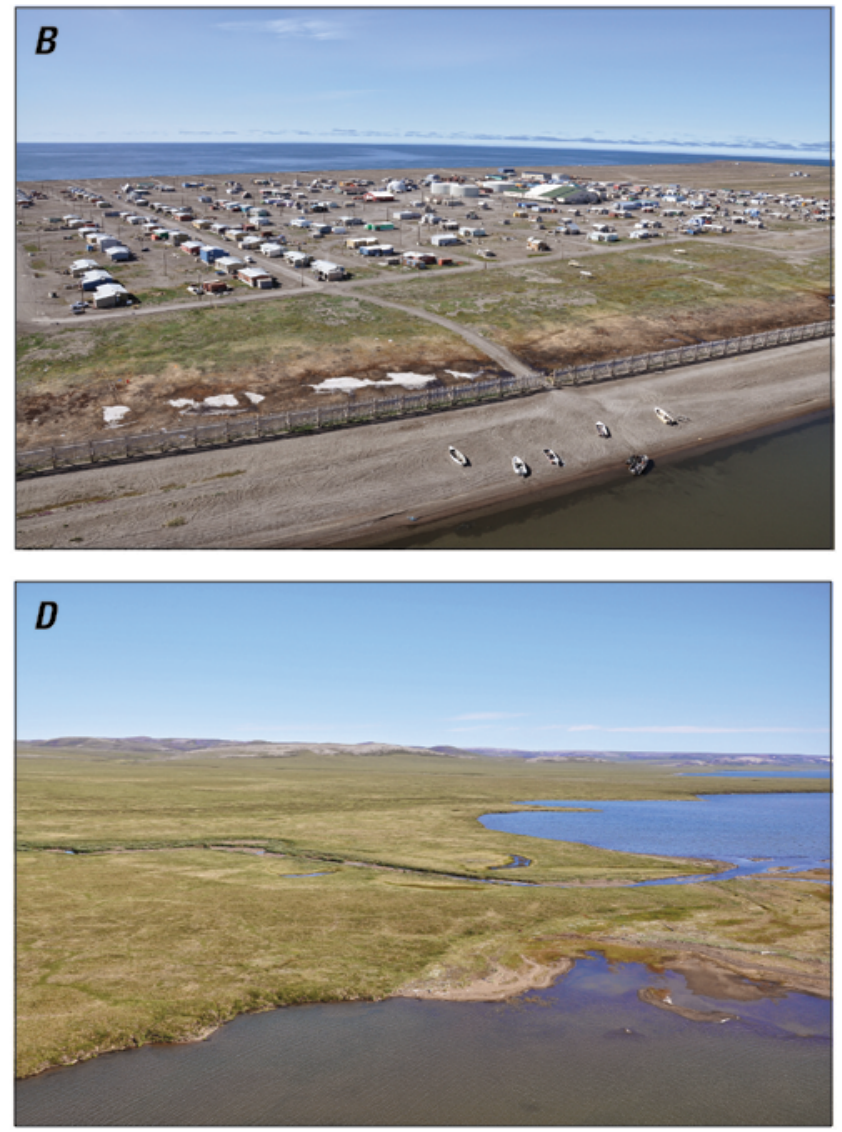

Figure 15. Aerial photographs showing examples of the coast in region 4. $A$, View to the south across the Point Hope peninsula with Cape Thompson in the background. $B$, The community of Point Hope; view from Marryat Inlet toward the southwest. $C$, Permafrost bluffs on the sheltered mainland coast of Marryat Inlet. $D$, The sheltered mainland coast of Aiautak Lagoon. Alaska ShoreZone Program (https:// shorezone.org) photographs taken in July 2012 (licensed under Creative Commons 3.0; http://creativecommons.org/licenses/by/3.0/). 


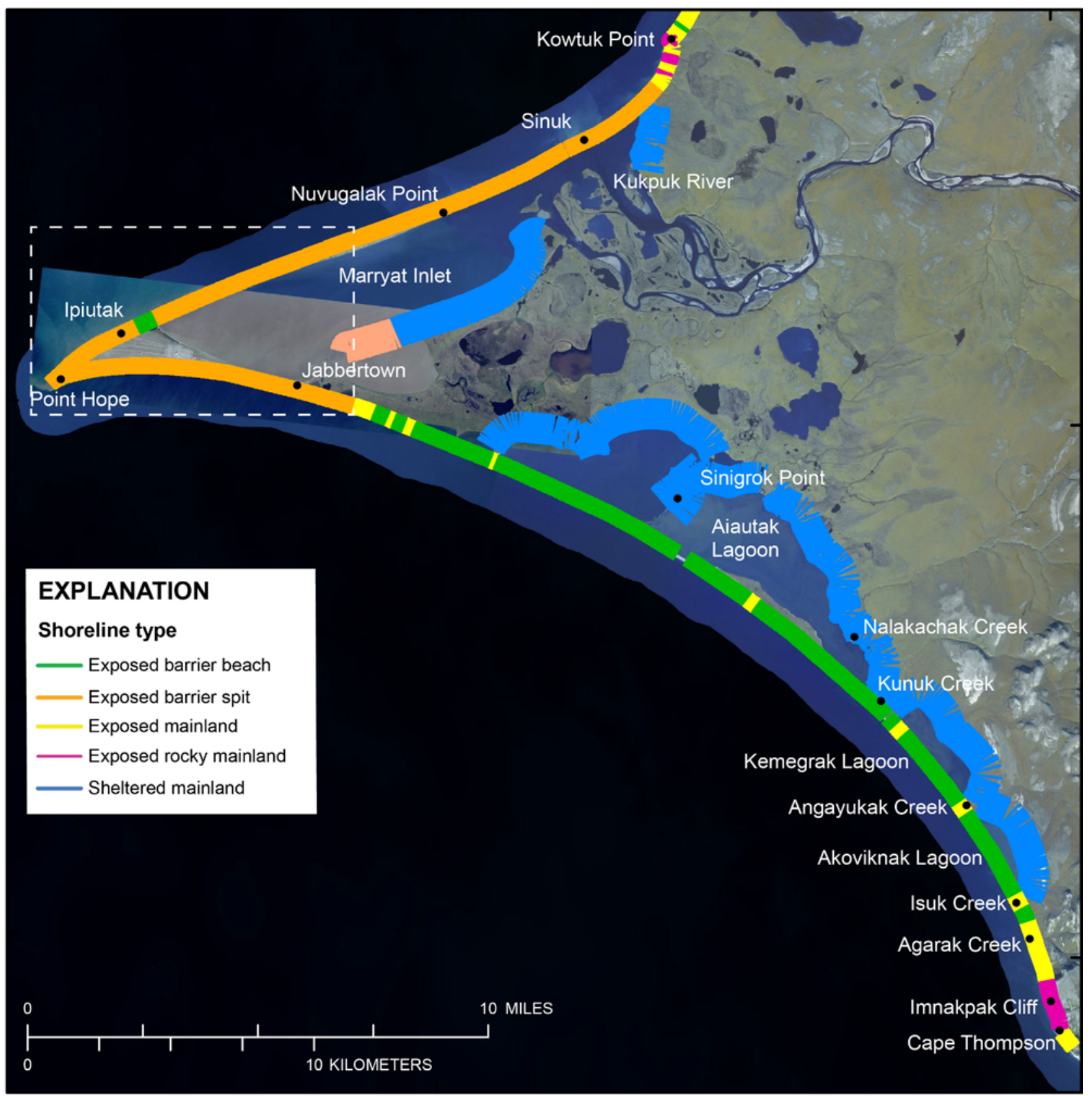

Base image from Alaska Geospatial Council and 2011 National Centre for Space Studies (CNES)

Figure 16. Map showing color-coded shoreline types in region 4 (Kowtuk Point to Cape Thompson). Dashed white outline shows the approximate location of figure 18. 


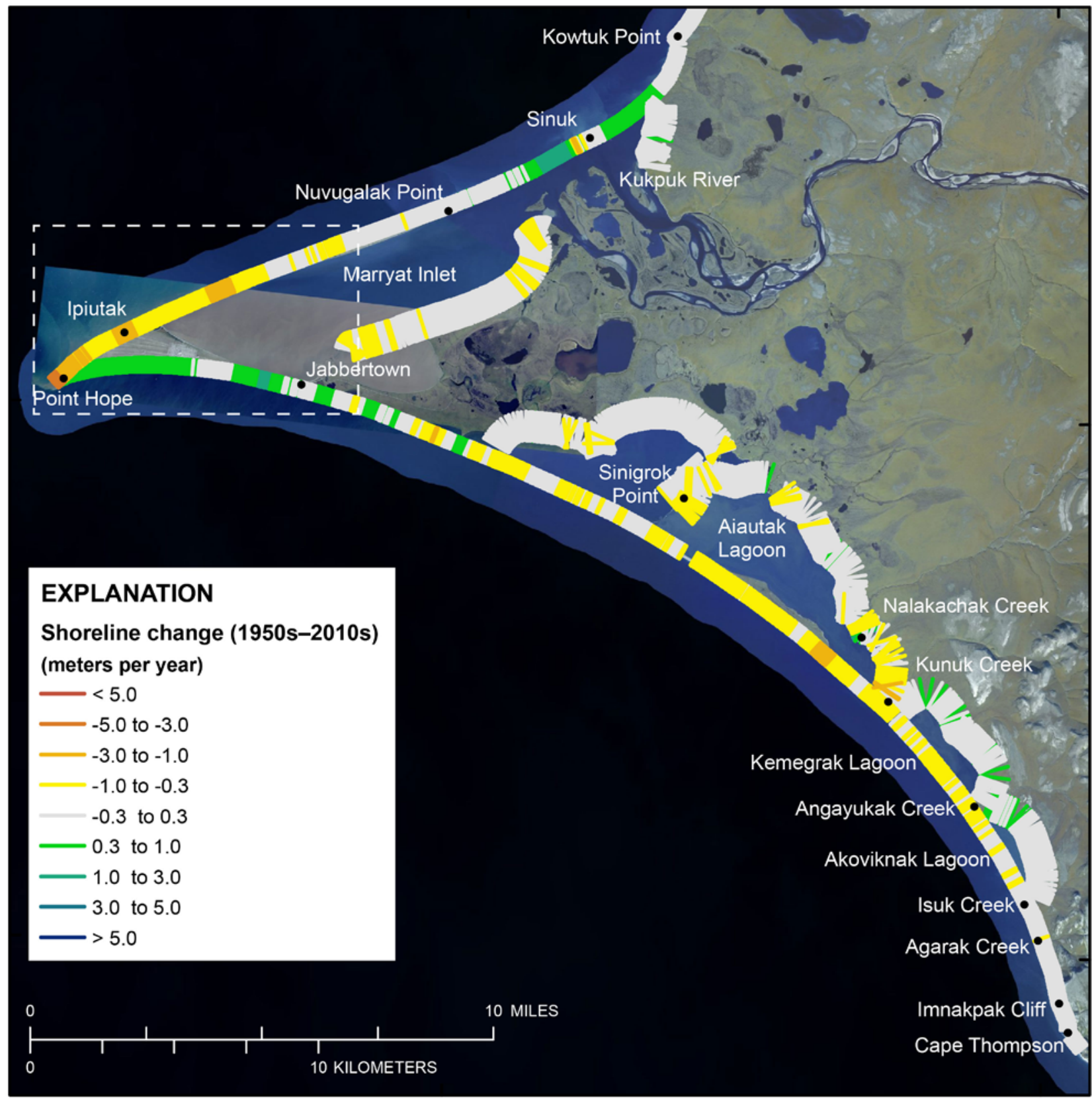

Base image from Alaska Geospatial Council and 2011 National Centre for Space Studies (CNES)

Figure 17. Map showing color-coded shoreline change rates in region 4 (Kowtuk Point to Cape Thompson) between 1950 and 2016. Dashed white outline shows the approximate location of figure 18. 


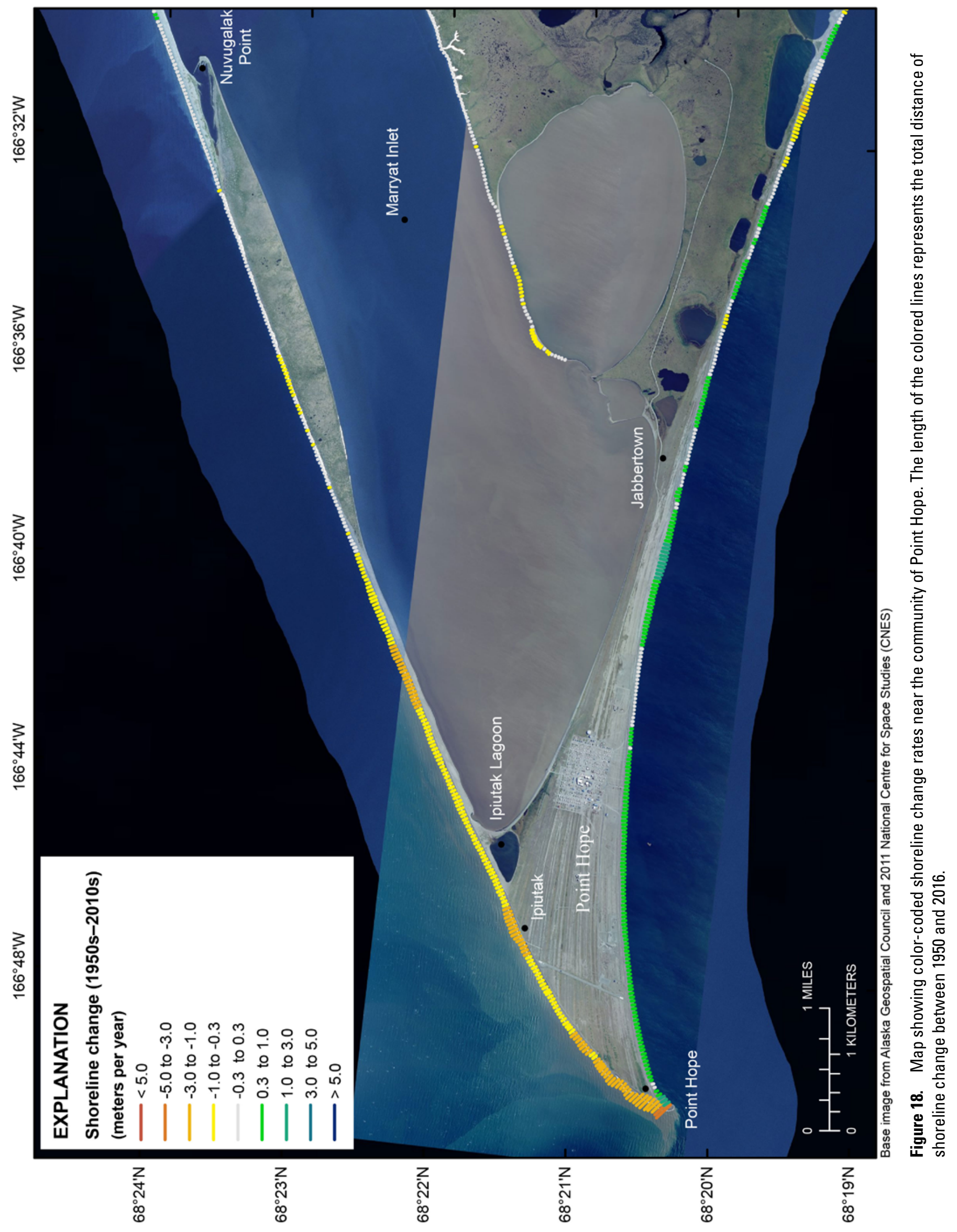




\section{Region 5: Cape Thompson to Asikpak Lagoon}

The coast of region 5 extends approximately $60 \mathrm{~km}$ south along the Chukchi Sea coast from Cape Thompson to Asikpak Lagoon. There is no coastal development nor population centers along this section of coast.

Region 5 is characterized by high-cliffed, rocky coast fronted by a discontinuous, narrow ribbon of beach from Cape Thompson south to Crowbill Point. Rockfall and landslide deposits are common along this section of coast. South of Crowbill Point and along the wide alluvial valley of Ogotoruk Creek, the coastal slope decreases and relatively wide $(>50 \mathrm{~m})$ beaches are persistent. From Kiktoya Creek south to Asikpak Lagoon, the coastal plain widens $(>500 \mathrm{~m})$ and alternating alluvial deposits and lagoons fronted by barrier beaches and spits dominate the landscape (fig. 19). Shoreline types in this region include exposed mainland, rocky mainland, barrier beach, and barrier spit (fig. 20).

Shoreline change rates in region 5 were calculated only on exposed open-ocean shorelines using 1950 T-sheets, 1978 AHAP photography, and 2016 aerial photography (table 2, fig. 4). No shoreline change rates were calculated along the stretch
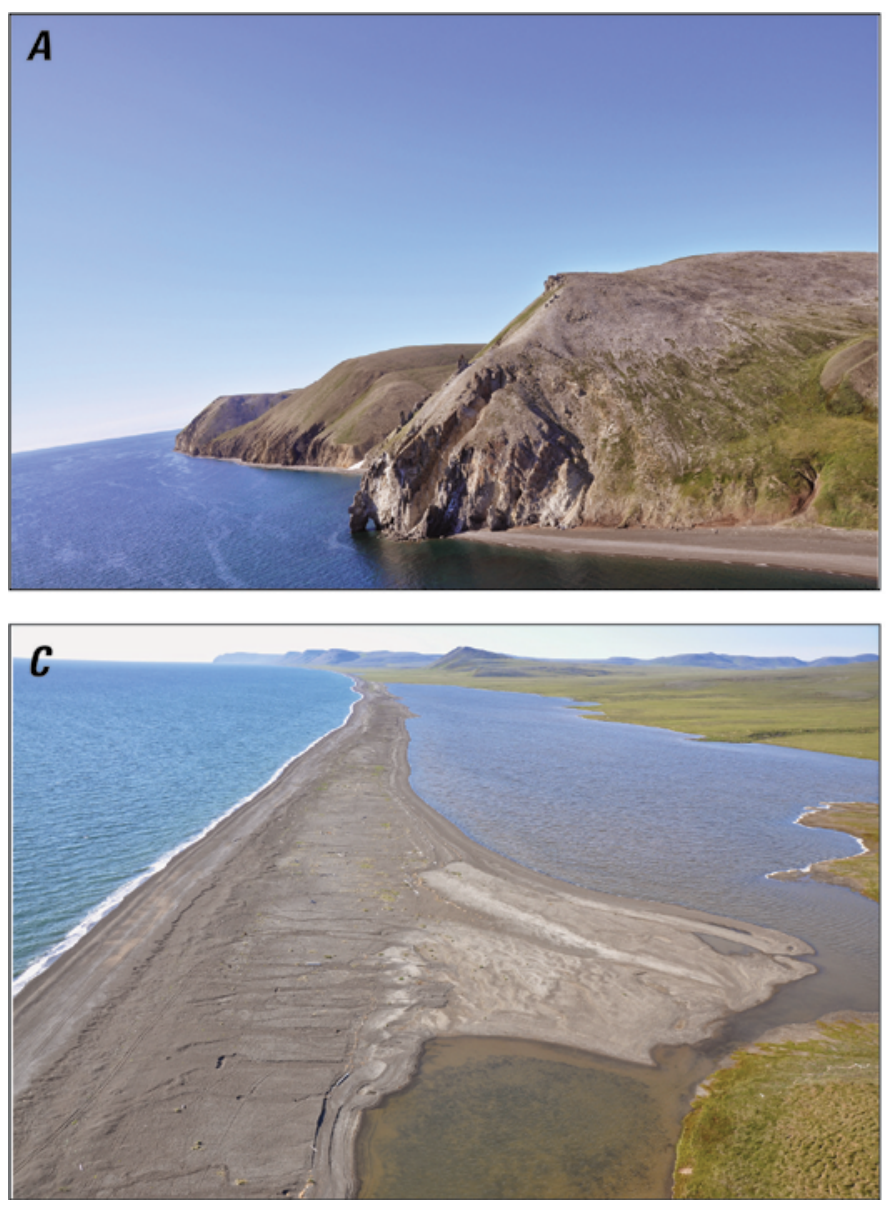

of coast between Cape Seppings and Asikpak Lagoon where AHAP imagery is missing (figs. 4, 21); however, 1950 and 2016 shorelines are included in the database. The region was on average slightly erosional over both the short and long term (56 and 77 percent of transects, respectively). Rates of change were generally low and near the limit of analytical uncertainty along this reach of coast. Changes rates were generally higher south of Kiktoya Creek. Regional shoreline change rates were low in this region, averaging $-0.1 \pm 0.1 \mathrm{~m} / \mathrm{yr}$ (ranging from -0.8 to $+0.4 \mathrm{~m} / \mathrm{yr}$ ) over the long term and $-0.1 \pm 0.3 \mathrm{~m} / \mathrm{yr}$ (ranging from -1.0 to +0.6 $\mathrm{m} / \mathrm{yr}$ ) over the short term (fig. 21, table 5). The highest erosion rates were measured on the barrier fronting Singoalik Lagoon over the long term (less than $-0.7 \mathrm{~m} / \mathrm{yr}$ ) and on the barrier fronting Mapsorak Lagoon over the short term (less than $-0.9 \mathrm{~m} / \mathrm{yr}$ ). The highest long-term accretion rates were measured on the north end of the barrier fronting Mapsorak Lagoon ( $>0.4 \mathrm{~m} / \mathrm{yr})$ and the highest short-term accretion rates ( $>0.5 \mathrm{~m} / \mathrm{yr})$ were measured on the barrier beach fronting Singoalik Lagoon and also along the rocky coast near Amaktusak Creek north of Crowbill Point, but this may be a spurious artifact of the poor AHAP imagery in the region (table 6).
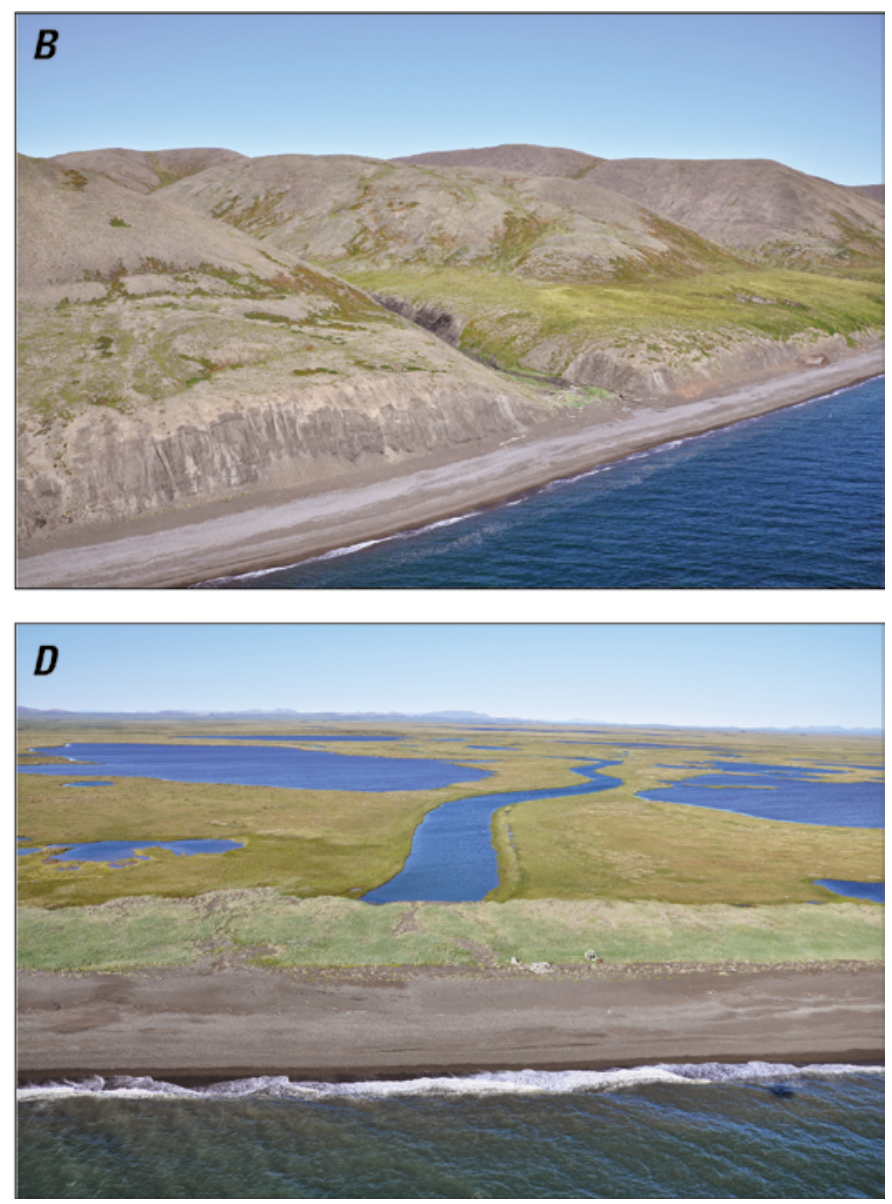

Figure 19. Aerial photographs showing examples of the coast in region 5. $A, A$ narrow ribbon of beach fronts the steep rocky coast north of Crowbill Point. $B$, A relatively wide beach fronts the steep coast near Kuropak Creek. $C, A$ barrier beach fronts Mapsorak Lagoon. View is to the northwest with Crowbill Point in the distance. $D, A$ vegetated barrier beach fronts the low-lying coastal plain near the Singoalik River. Alaska ShoreZone Program (https://shorezone.org) photographs taken in July 2012 (licensed under Creative Commons 3.0; http://creativecommons.org/licenses/by/3.0/). 
$68^{\circ} \mathrm{N}$

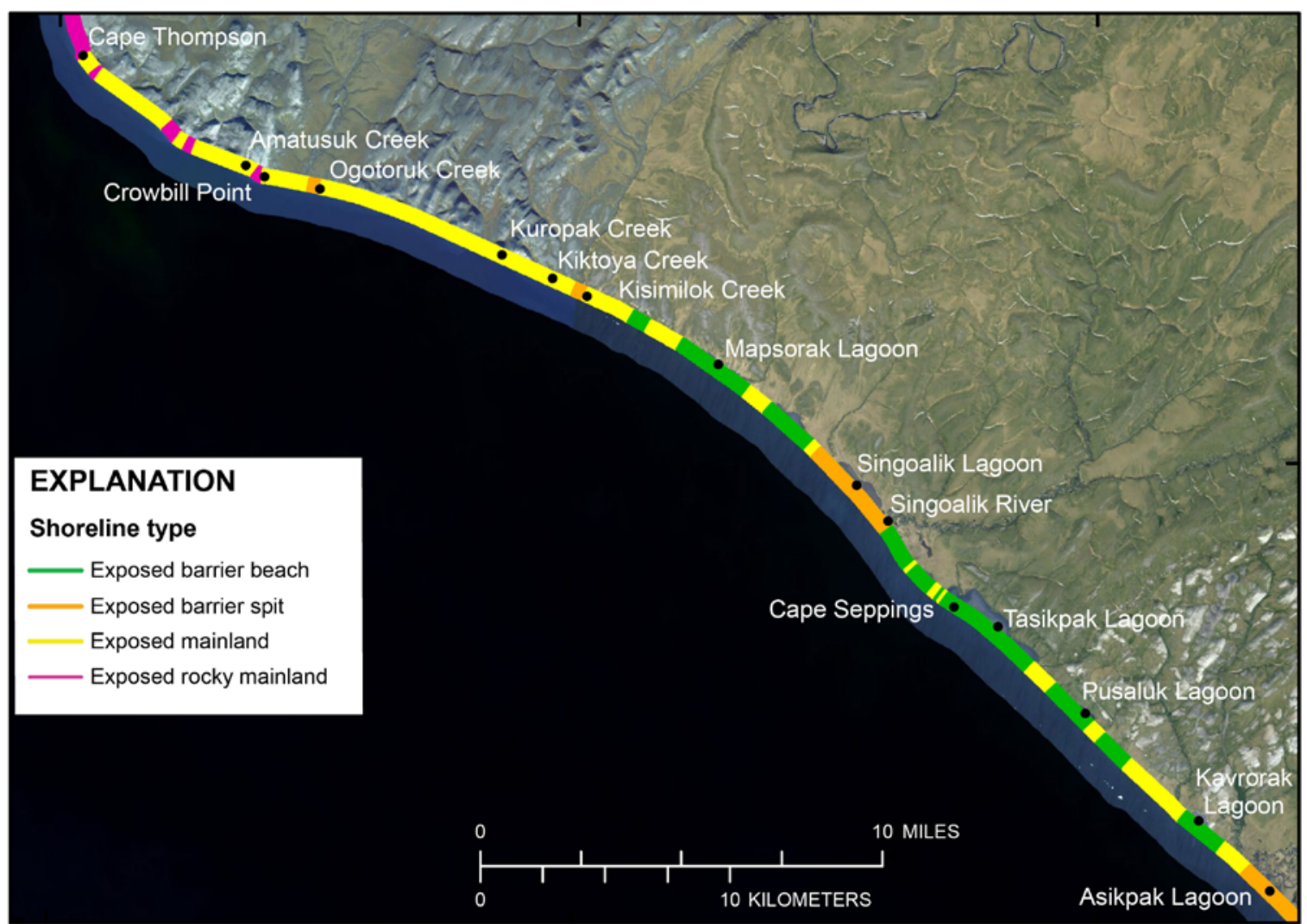

$67^{\circ} 50^{\prime} \mathrm{N}$

Base image from Alaska Geospatial Council and 2011 National Centre for Space Studies (CNES)

Figure 20. Map showing color-coded shoreline types in region 5 (Cape Thompson to Asikpak Lagoon).

$166^{\circ} \mathrm{W}$

$165^{\circ} 30^{\prime} \mathrm{W}$

$165^{\circ} \mathrm{W}$

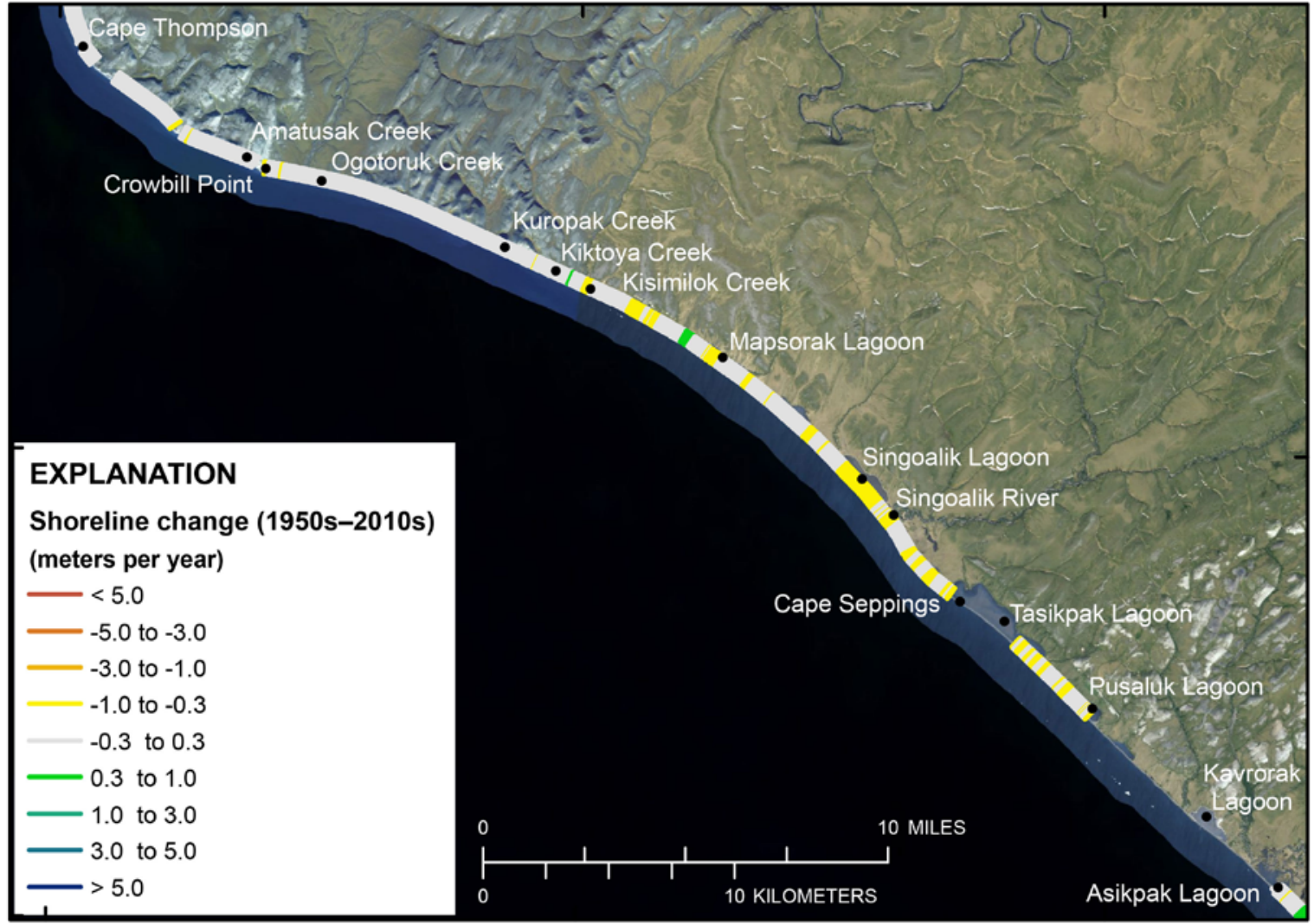

Base image from Alaska Geospatial Council and 2011 National Centre for Space Studies (CNES)

Figure 21. Map showing color-coded shoreline change rates in region 5 (Cape Thompson to Asikpak Lagoon) between 1950 and 2016. 


\section{Region 6: Asikpak Lagoon to Sheshalik Spit (Cape Krusenstern National Monument)}

Region 6 extends approximately $140 \mathrm{~km}$ along the Chukchi Sea coast from Asikpak Lagoon to Sheshalik Spit. Infrastructure and development along this section of coast include the community of Kivalina, with a population of 442 in 2018 (State of Alaska, 2019), and Red Dog Dock, which is also the location of NOAA National Water Level Observation Network Station no. 9491094 (NOAA, 2018b). Red Dog Dock services Red Dog mine, an open-pit zinc, lead, and germanium mine located $84 \mathrm{~km}$ (52 miles) inland from the coast. A large part of region 6, between Ipiavik Lagoon and Sheshalik Spit, is part of Cape Krusenstern National Monument.

This coast of region 6 is predominantly barrier beaches and spits fronting low-lying tundra, salt marshes, and lagoons. The coastal plain is fairly wide ( $>3 \mathrm{~km})$ and gently sloping, and numerous alluvial valleys and deltas segment the coast. Cape Krusenstern is formed by an extensive complex of vegetated, arcuate welded beach ridges (fig. 22). Shoreline types in this region include exposed mainland, barrier beach, barrier island, and barrier spit (fig. 23).

Shoreline change rates for region 6 were calculated only on exposed open-ocean shorelines using three historical digital shorelines provided by Lestak and others (2010) that are derived from 1952 black and white aerial photographs, 1978 and 1980 AHAP color-infrared aerial photographs, and 2003 natural-color aerial photographs. The modern shoreline was derived from 2016 natural-color aerial photographs (table 2, fig. 4). Because of the additional 2003 shoreline in this region, both long-term and short-term rates were calculated using the linear regression method. This section of coast was primarily erosional over both the long and short term (63 and 51 percent of transects, respectively). Shoreline change rates were moderate to low, but spatially variable, averaging $-0.1 \pm 0.1 \mathrm{~m} / \mathrm{yr}$ (ranging from -1.8 to $2.6 \mathrm{~m} / \mathrm{yr}$ ) over the long term and $-0.0 \pm 0.2 \mathrm{~m} / \mathrm{yr}$ (ranging from -2.9 to $4.2 \mathrm{~m} / \mathrm{yr}$ ) over the short term (fig. 24, table 5). The highest long-term erosional rates were measured at Cape Krusenstern and the highest short-term erosional rates were measured just south of Red Dog Dock $(-1.8 \mathrm{~m} / \mathrm{yr}$ and $-2.9 \mathrm{~m} / \mathrm{yr}$, respectively). High erosional rates were also measured south of Red Dog Dock over the long term as well as significant sediment accretion north of the dock over the same time periods (fig. 25). This is a common pattern of shoreline change associated with shore-perpendicular structures that block alongshore transport of sediment. The highest long- and shortterm accretion rates were measured at Sheshalik Spit $(>2.0$ and $>3.0 \mathrm{~m} / \mathrm{yr}$, respectively; fig. 24, table 6).
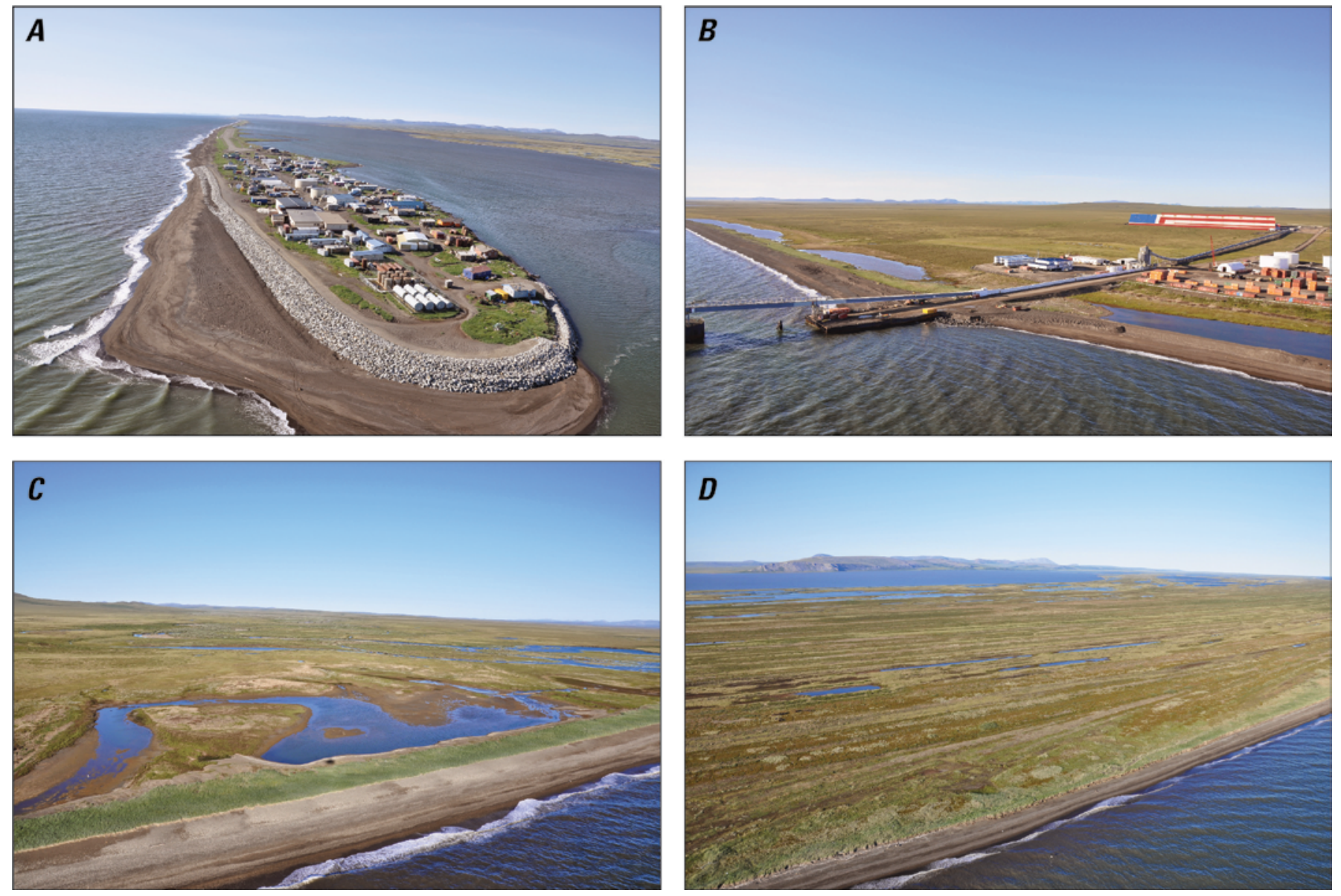

Figure 22. Aerial photographs showing examples of the coast in region 6. A, A rock revetment fronts a part of the coastal community of Kivalina. $B$, Red Dog Dock; $C$, A barrier beach near Imik Lagoon. D, Accretionary beach ridges at Cape Krusenstern. Alaska ShoreZone Program (https://shorezone.org) photographs taken in July 2012 (licensed under Creative Commons 3.0; http://creativecommons.org/licenses/by/3.0/). 
Near the community of Kivalina, rates of shoreline change were generally low and on average accretional over the long term, averaging $0.1 \pm 0.2 \mathrm{~m} / \mathrm{yr}$ (ranging from -0.3 to $+0.5 \mathrm{~m} / \mathrm{yr}$ ), and short term, averaging $0.1 \pm 0.7 \mathrm{~m} / \mathrm{yr}$ (ranging from -0.5 to $+0.8 \mathrm{~m} /$ yr). The net shoreline movement near Kivalina averaged $+3.9 \mathrm{~m}$ between 1952 and 2016, with a maximum retreat of $-27 \mathrm{~m}$ near the north end of the airstrip and maximum accretion of $+49 \mathrm{~m}$ at the south end of the spit (fig. 26, table 5).

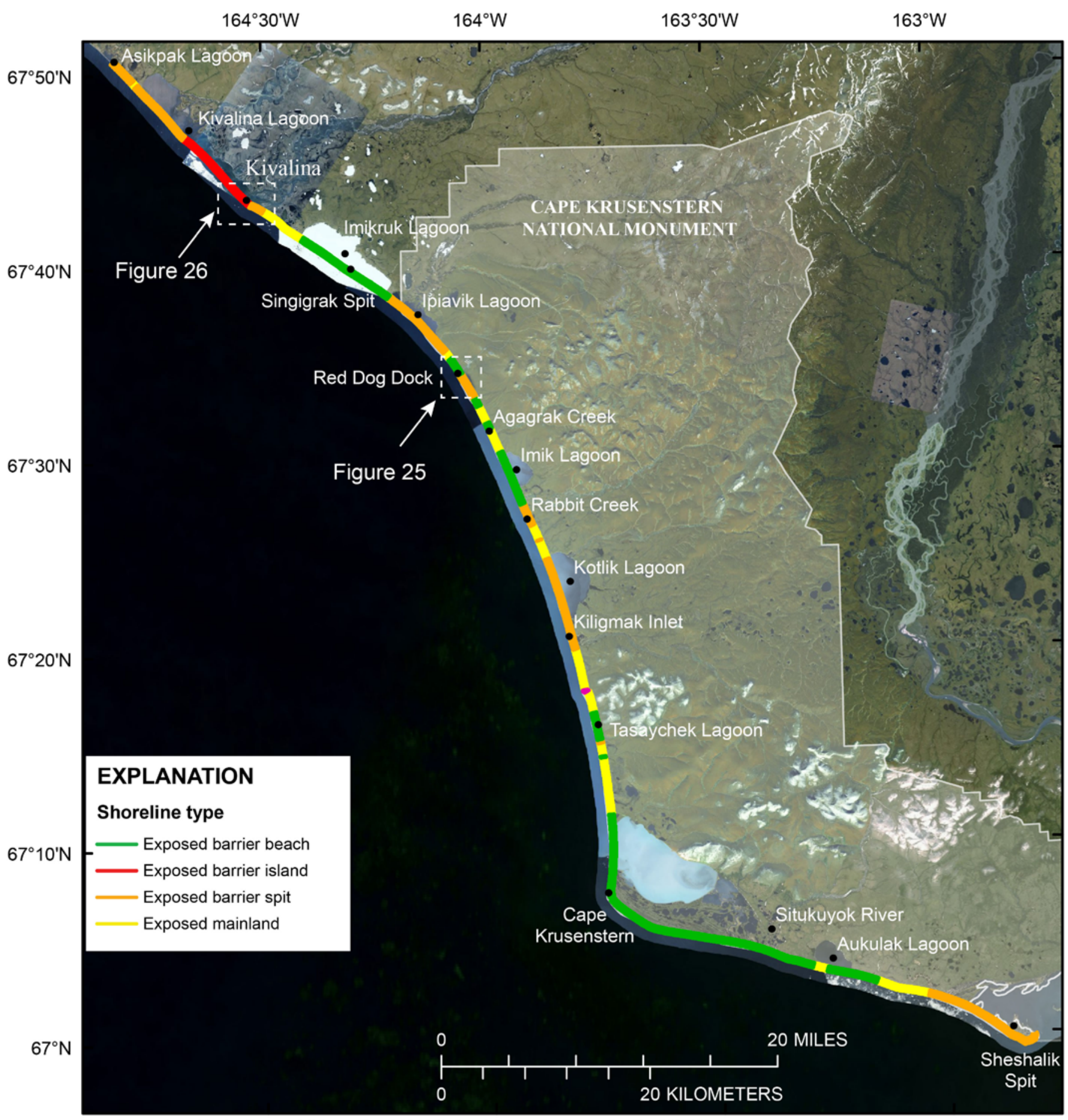

Base image from Alaska Geospatial Council and 2011 National Centre for Space Studies (CNES)

Figure 23. Map showing color-coded shoreline types in region 6 (Asikpak Lagoon to Sheshalik Spit). Dashed white outlines near Red Dog Dock and Kivalina show approximate locations of figures 25 and 26, respectively. 


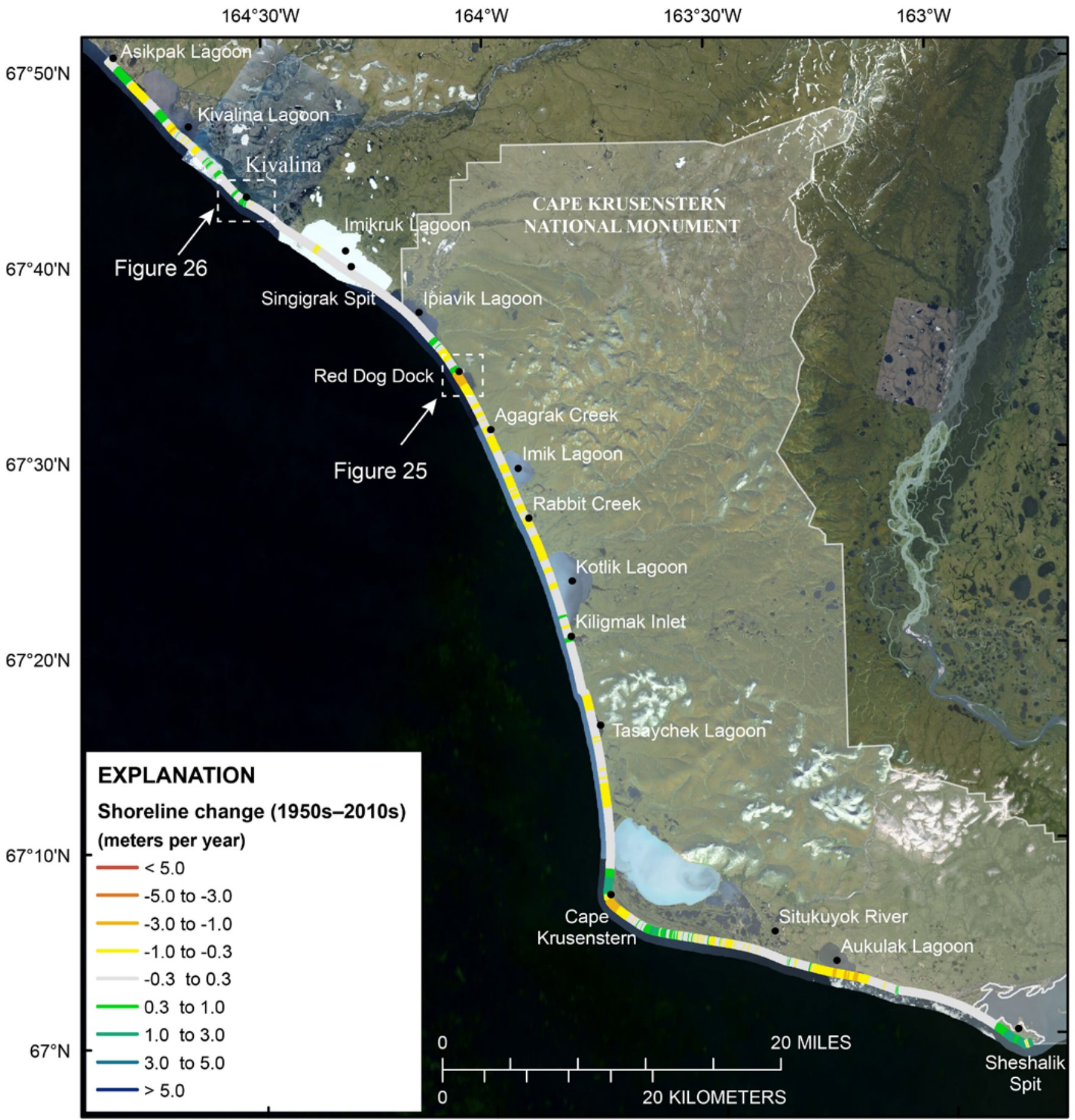

Base image from Alaska Geospatial Council and 2011 National Centre for Space Studies (CNES)

Figure 24. Map showing color-coded shoreline change rates in region 6 (Aspilak Lagoon to Sheshalik Spit) between 1950 and 2016. Dashed white outlines near Red Dog Dock and Kivalina show approximate locations of figures 25 and 26 , respectively. 


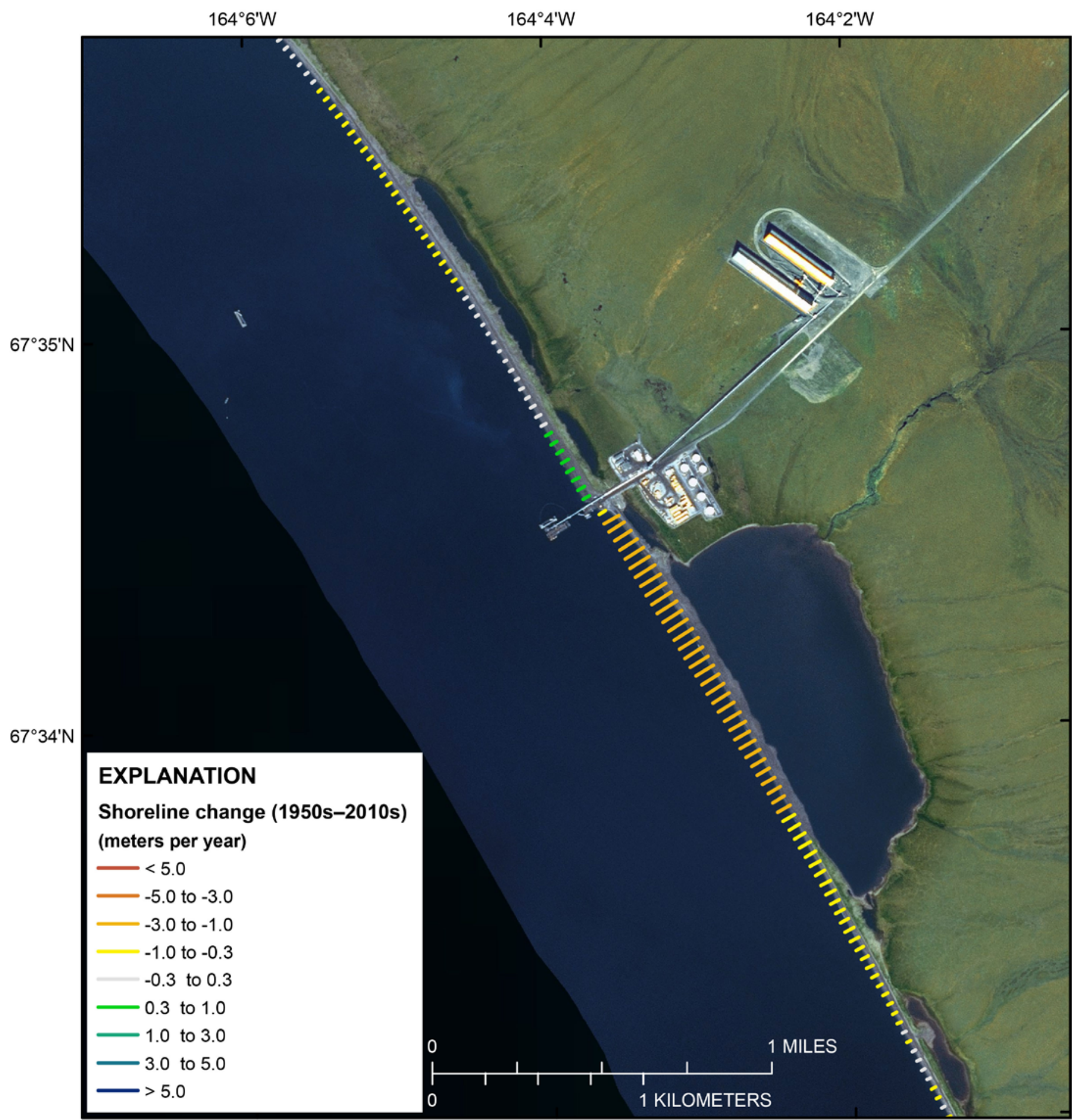

Base image from Alaska Geospatial Council and 2011 National Centre for Space Studies (CNES)

Figure 25. Map showing color-coded shoreline change rates near Red Dog Dock. The length of the colored lines represents the total distance of shoreline change between 1952 and 2016. 


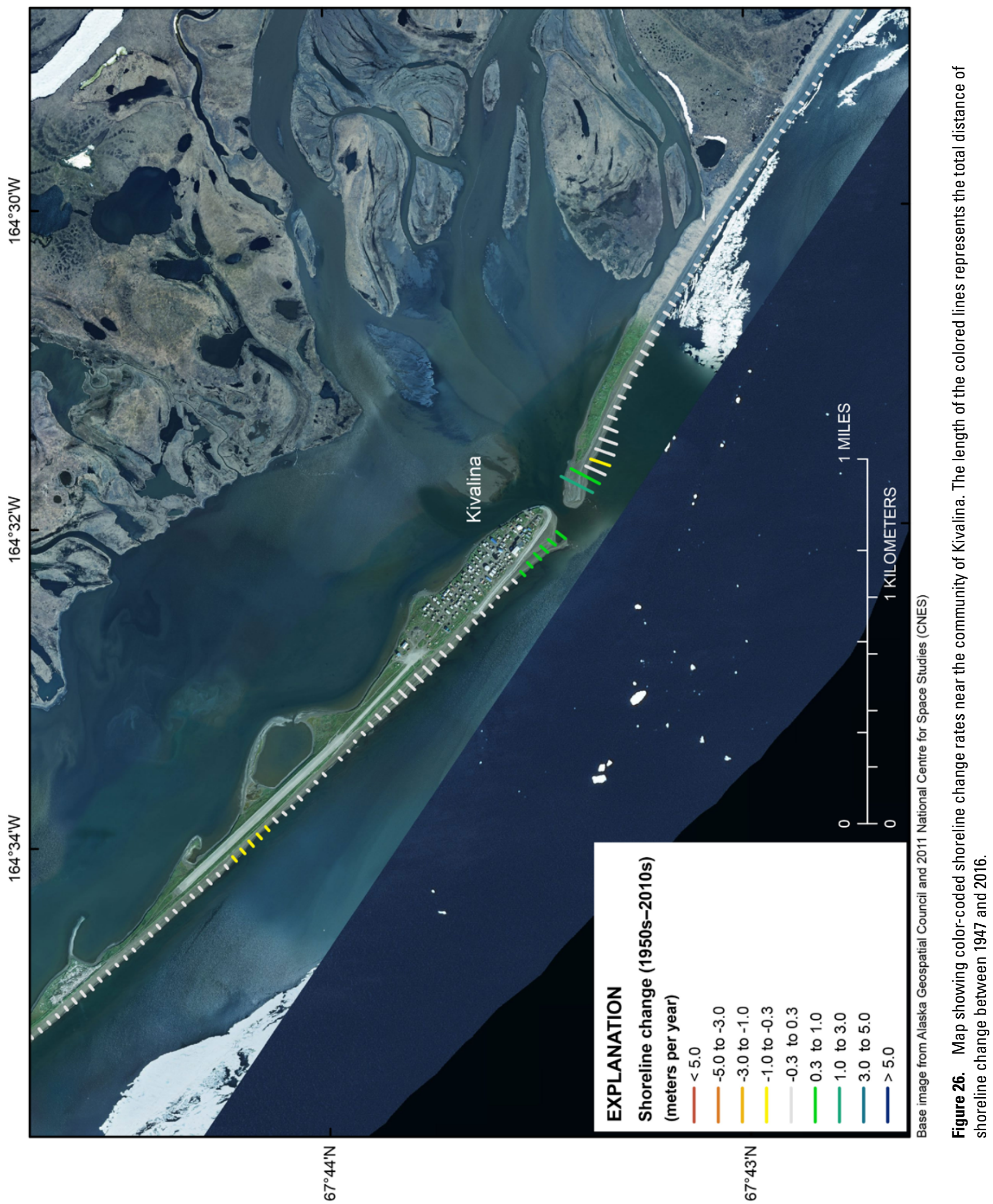




\section{Region 7: Kotzebue to Sullivan Lake}

Region 7 extends approximately $195 \mathrm{~km}$ along the Kotzebue Sound coast from the Noatak River to Sullivan Lake. Infrastructure and development along this section of coast include the communities of Kotzebue (2018 population of 3,121$)$ and Deering (2018 population of 168) (State of Alaska, 2019). The coast is characterized by narrow to wide beaches fronting low to moderately high, well-vegetated permafrost bluffs and rocky cliffs. Low-lying spits and barrier beaches are present near Kotzebue and Deering and fronting several streams (fig. 27). Only exposed open-coast shorelines are included in the shoreline change analysis in this region. Shoreline types include exposed mainland, rocky mainland, barrier beach, barrier island, and barrier spit (fig. 28).

Shoreline change rates for region 7 were determined using 1950 and 1951 T-sheets, 1978 AHAP photography, and 2016 aerial photography (table 2, fig. 4). 1950s-era shoreline data do not exist from about $8 \mathrm{~km}$ west of Kiwalik Inlet to Sullivan Lake. 1980s era shoreline data do not exist from the headland about $10 \mathrm{~km}$ west of Cape Deceit and Sullivan Lake. Long-term rates were calculated from Kotzebue to $\sim 8 \mathrm{~km}$ west of Kiwalik Lagoon and short-term rates were calculated from Kotzebue to the headland about $10 \mathrm{~km}$ west of Cape Deceit (fig. 15). Region 7 was primarily erosional over
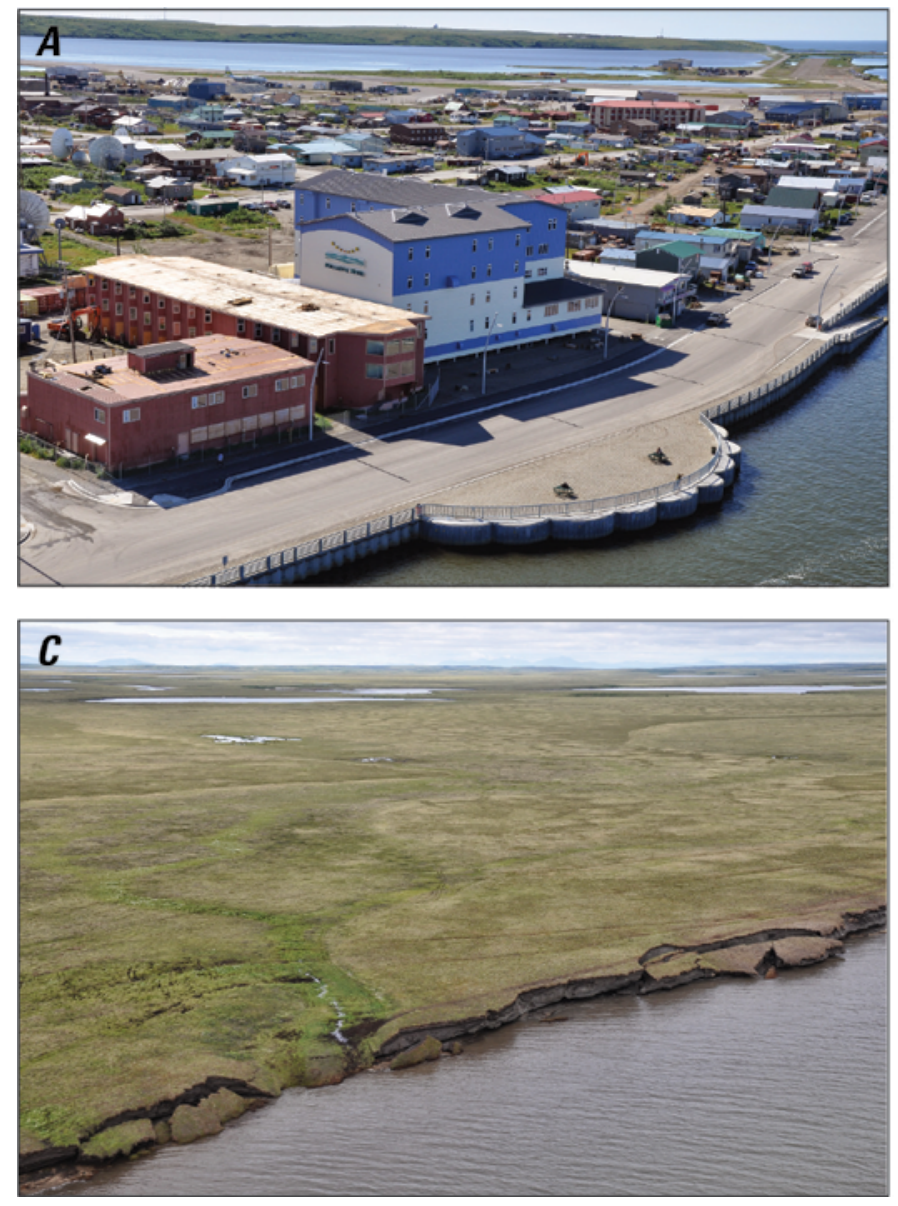

both the long and short term (64 and 57 percent of transects, respectively). Shoreline change rates were generally low, averaging $-0.2 \pm 0.1$ and $-0.3 \pm 0.3 \mathrm{~m} / \mathrm{yr}$ (ranging from -3.9 to $2.1 \mathrm{~m} / \mathrm{yr}$ and -5.6 to $3.8 \mathrm{~m} / \mathrm{yr}$ ) for the long and short term, respectively (fig. 29, table 5). Change rates were higher along the Baldwin Peninsula south of Cape Blossom. The highest long- and short-term erosional rates measured in region 7 were southeast of Cape Blossom (less than $-2.0 \mathrm{~m} / \mathrm{yr}$ ). The highest long-term accretional rates were measured near Kiwalik, at the mouth of Kiwalik Lagoon ( $>1.0 \mathrm{~m} / \mathrm{yr}$ ). The highest short-term accretional rates were measured at the spit fronting Kiwalik Lagoon and north of Choris Peninsula ( $>0.7 \mathrm{~m} / \mathrm{yr}$; table 6$)$.

Near Kotzebue, the shoreline was relatively stable during the study period with long-term rates of shoreline change averaging $0.0 \pm 0.1 \mathrm{~m} / \mathrm{yr}$ (ranging from -0.8 to $+0.6 \mathrm{~m} / \mathrm{yr}$ ) and short-term rates averaging $0.0 \pm 0.3 \mathrm{~m} / \mathrm{yr}$ (ranging from -0.6 to $+0.9 \mathrm{~m} / \mathrm{yr}$ ). Maximum long- and short-term retreat distances ( -50 and $-23 \mathrm{~m}$, respectively) were measured on the beaches and spits east of the town (fig. 30). Maximum progradation distances ( $+40 \mathrm{~m}$ and $+33 \mathrm{~m}$, respectively) were measured in front of the Kotzebue airstrip and are associated with the construction of a coastal protection structure (fig. 16). Near Deering, the mean rate of short-term shoreline change was $+0.1 \pm 0.3 \mathrm{~m} / \mathrm{yr}$ (ranging from -0.3 to $+0.5 \mathrm{~m} / \mathrm{yr}$; fig. 31 ).
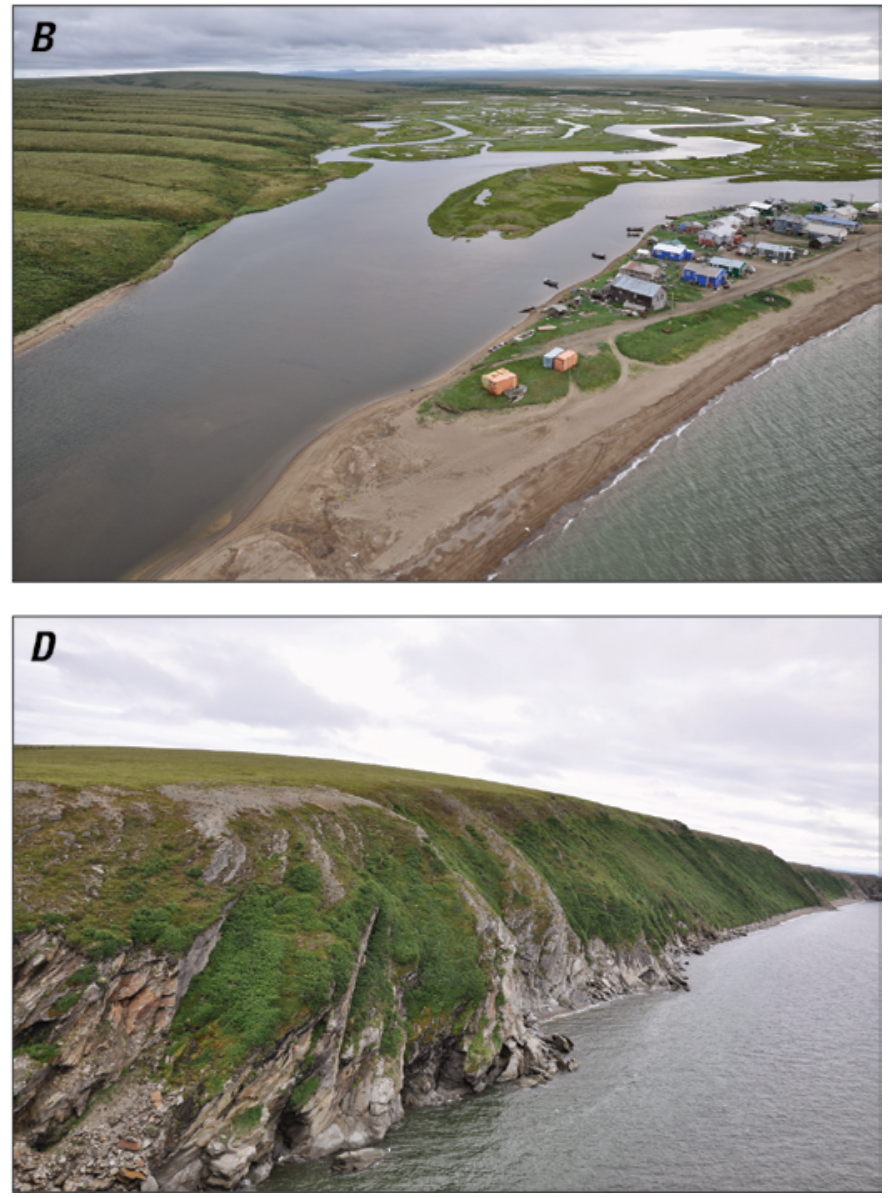

Figure 27. Aerial photographs showing examples of the coast in region 7. $A$, A seawall fronts a part of the community of Kotzebue. $B$, The community of Deering. $C$, Rapidly eroding, ice-rich permafrost bluffs east of Cape Blossom. $D$, Narrow beaches along the rocky coast of the Choris Peninsula. Alaska ShoreZone Program (https://shorezone.org) photographs taken in July 2012 (licensed under Creative Commons 3.0; http://creativecommons.org/licenses/by/3.0/). 


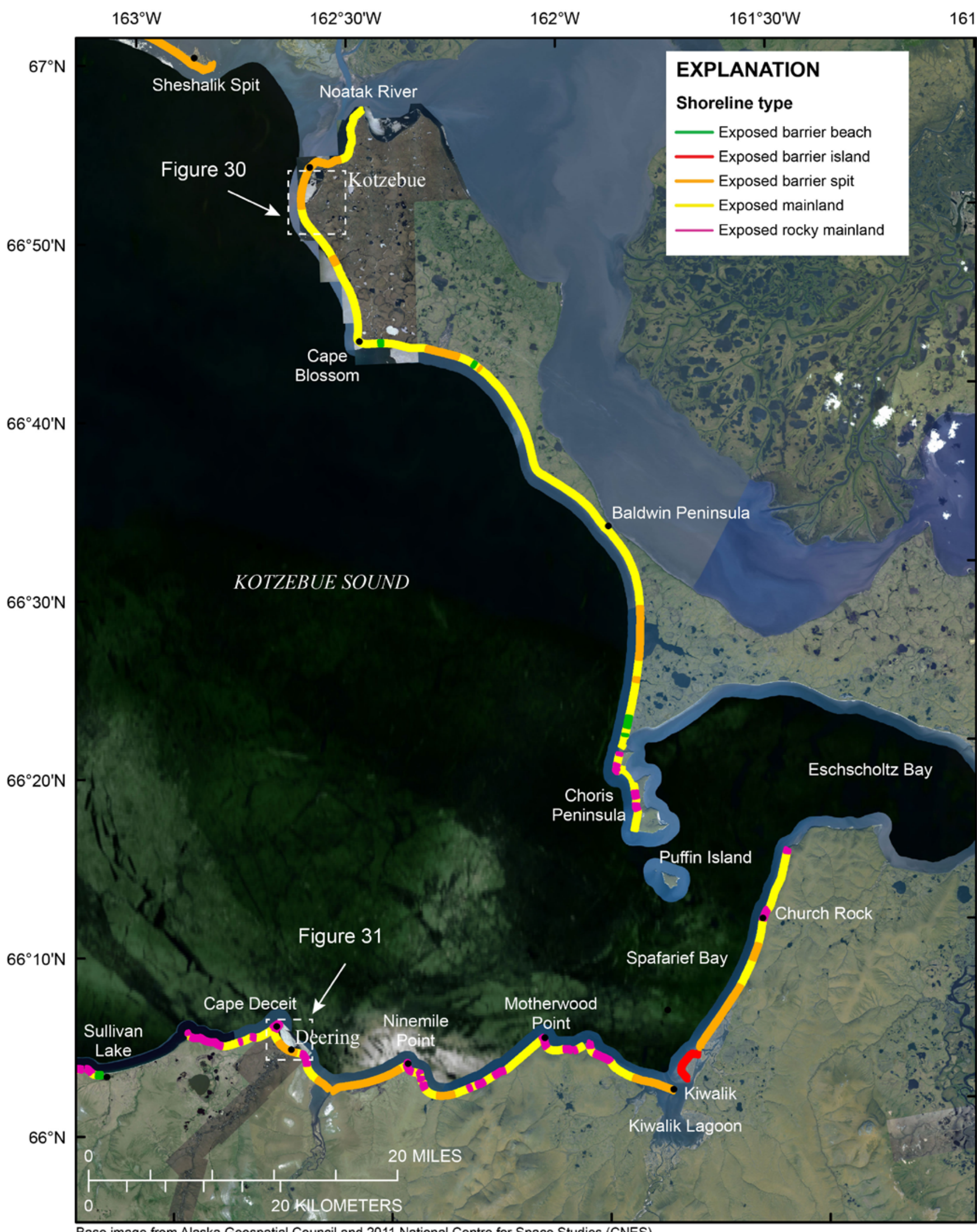

Base image from Alaska Geospatial Council and 2011 National Centre for Space Studies (CNES)

Figure 28. Map showing color-coded shoreline types in region 7 (Kotzebue to Sullivan Lake). Dashed white outlines near Kotzebue and Deering show the approximate locations of figures 30 and 31 , respectively. 


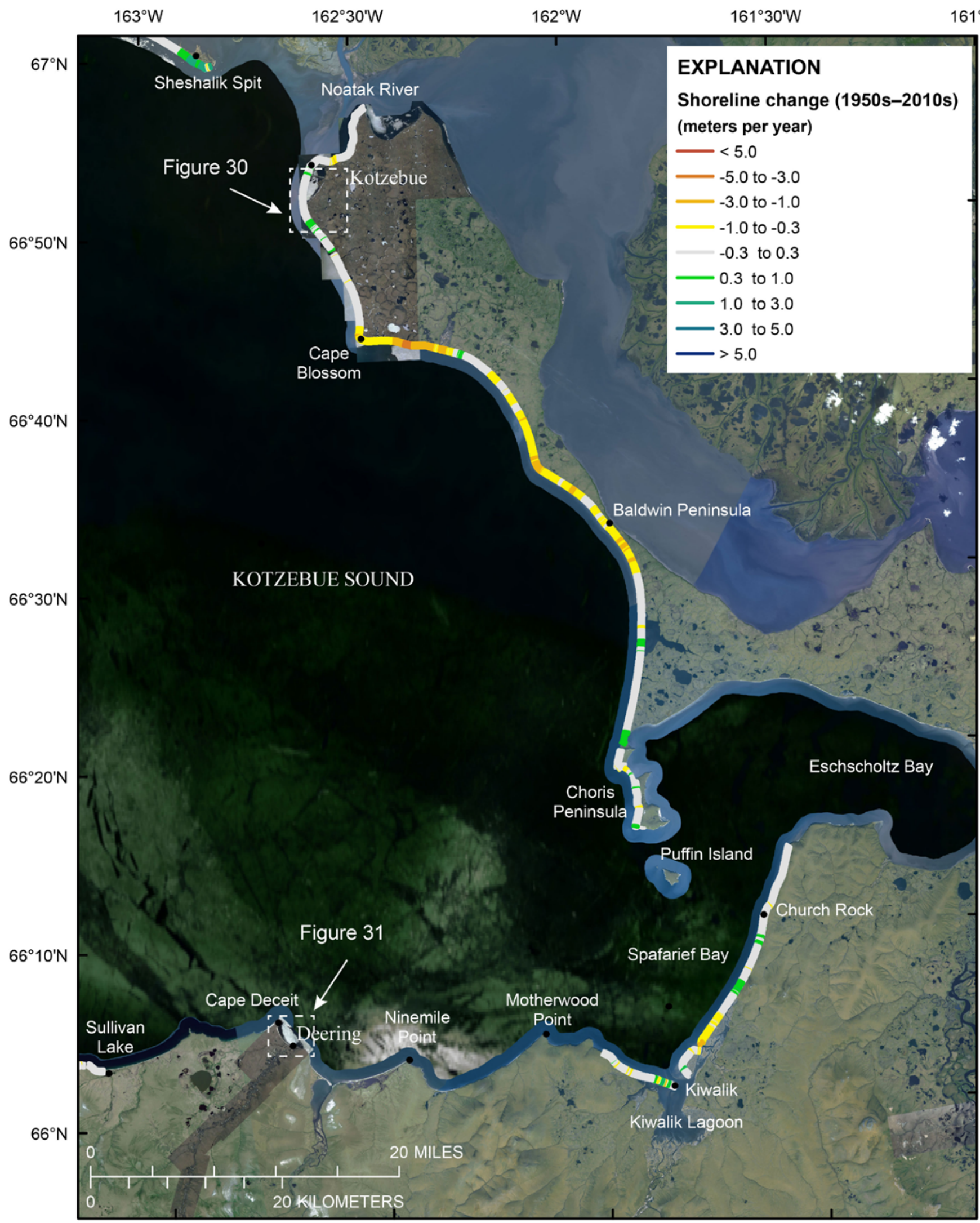

Base image from Alaska Geospatial Council and 2011 National Centre for Space Studies (CNES)

Figure 29. Map showing color-coded shoreline change rates in region 7 (Kotzebue to Sullivan Lake) between 1950 and 2016. Dashed white outlines near Kotzebue and Deering show the approximate locations of figures 30 and 31, respectively. 


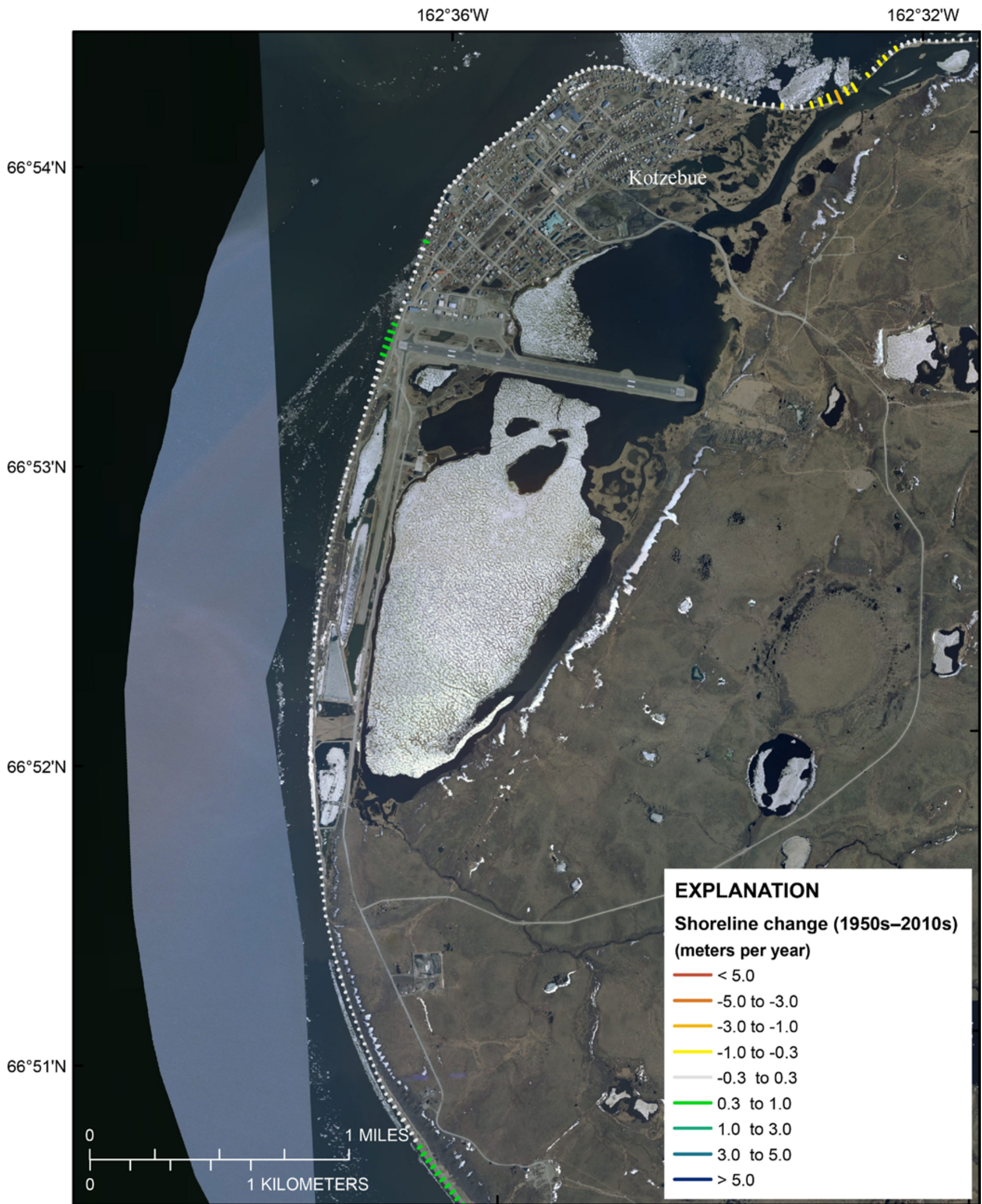

Base image from Alaska Geospatial Council and 2011 National Centre for Space Studies (CNES)

Figure 30. Map showing color-coded shoreline change rates near the community of Kotzebue. The length of the colored lines represents the total distance of shoreline change between 1950 and 2016. 


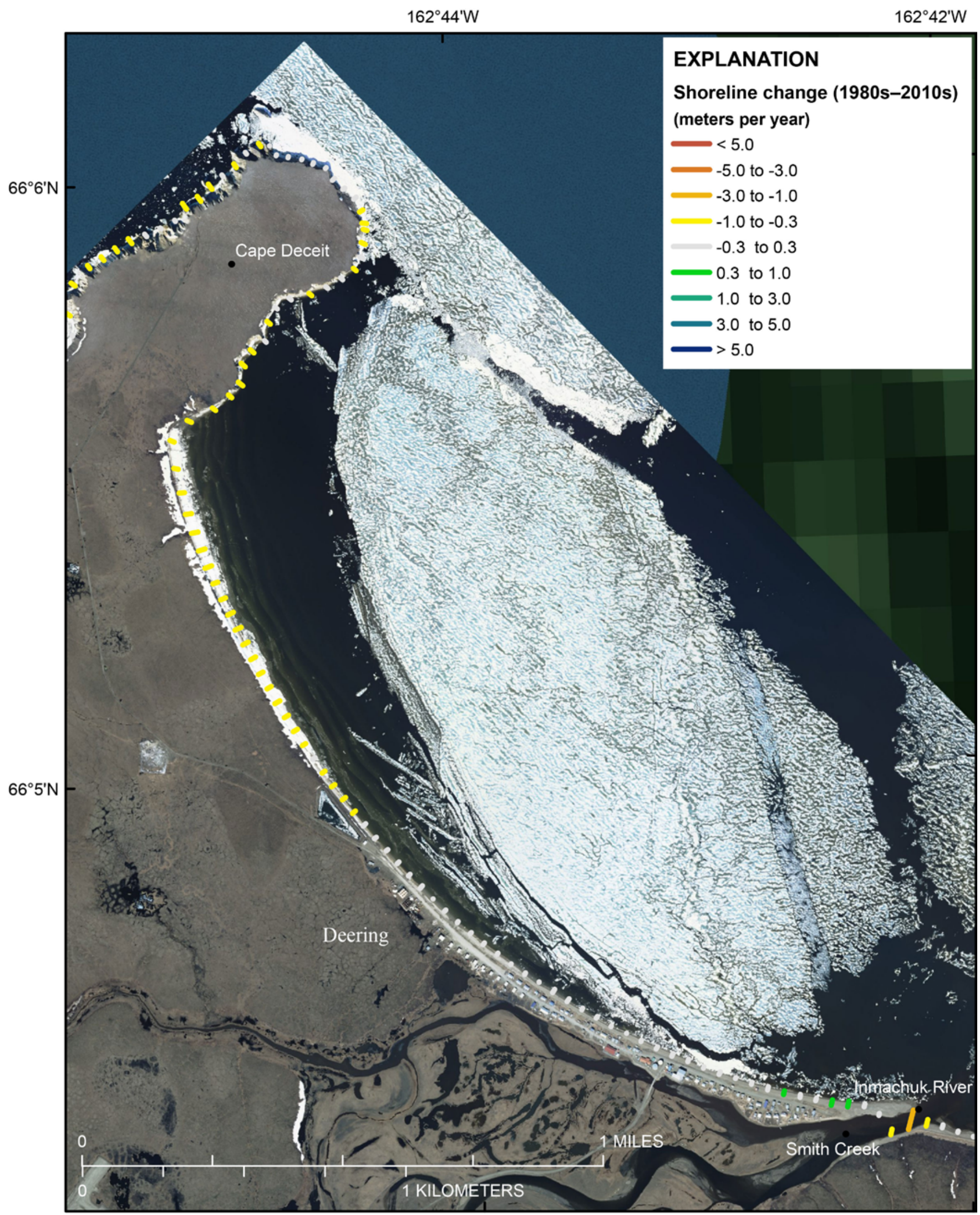

Base image from Alaska Geospatial Council and 2011 National Centre for Space Studies (CNES)

Figure 31. Map showing color-coded shoreline change rates near the community of Deering. The length of the colored lines represents the total distance of shoreline change between 1978 and 2016. 


\section{Region 8: Sullivan Lake to Cape Prince of Wales (Bering Land Bridge National Preserve)}

Region 8 extends approximately $313 \mathrm{~km}$ from Sullivan Lake to Cape Prince of Wales. Infrastructure and development along this section of coast include the communities of Shishmaref (2018 population of 598) and Wales (2018 population of 165) (State of Alaska, 2019). A large part of the region is part of Bering Land Bridge National Preserve. This coast is primarily characterized by a mixture of barrier-lagoon systems, ice-rich permafrost bluffs, and dune-ridge/aggrading spit complexes (fig. 32). Shoreline types in this region include exposed mainland, rocky mainland, barrier beach, barrier island, and barrier spit (fig. 33).

Shoreline change rates for region 8 were calculated only on exposed open-ocean shorelines using three historical digital shorelines provided by Lestak and others (2010) that are derived from 1949, 1950, and 1955 black and white aerial photographs; 1978 and 1985 AHAP color-infrared aerial photographs; and 2003 natural-color aerial photographs. The modern shoreline was derived from 2015 and 2016 natural-color aerial photographs (table 2, fig. 4). There is an approximately 4-km-long gap in the 1950s-era shoreline data near Cape Espenberg, where no shortor long-term rates were calculated. There is an approximately
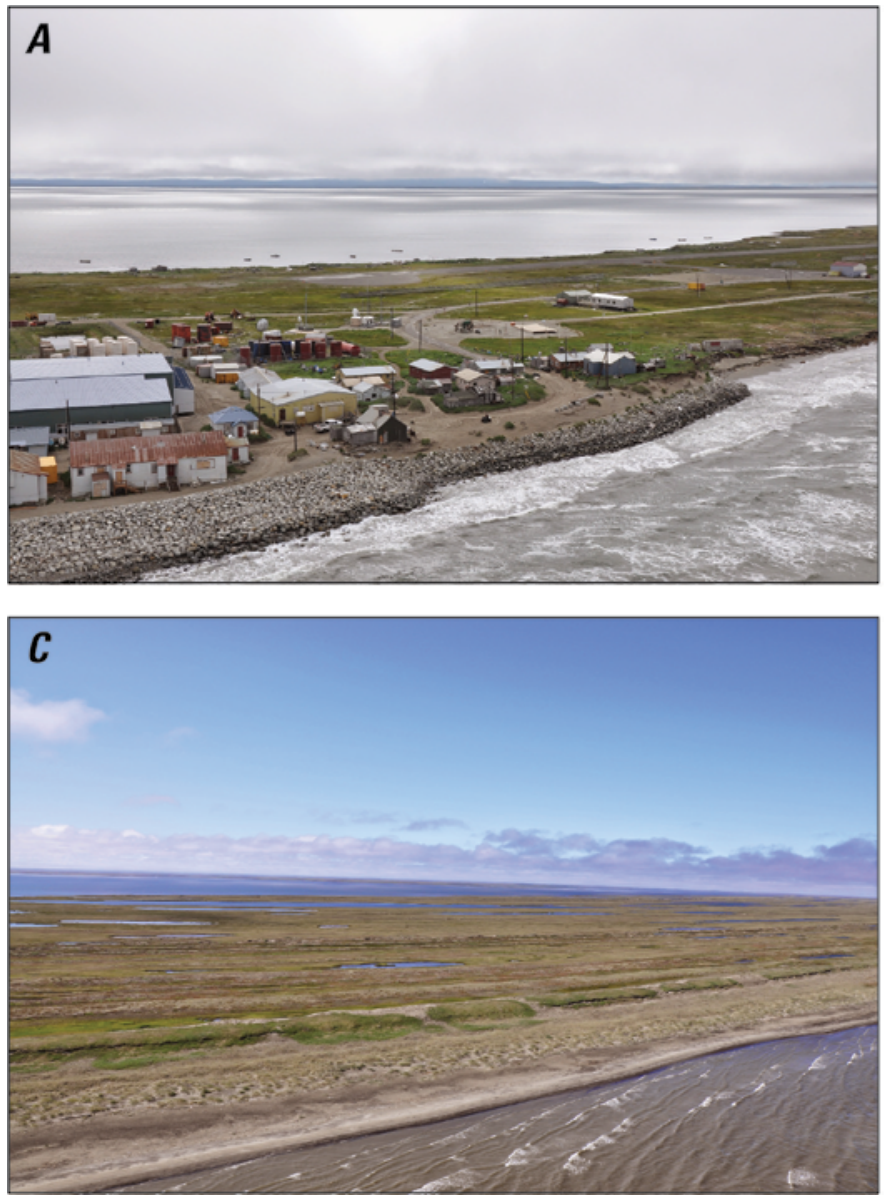

21-km-long gap in the 2010s-era shoreline data fronting Lopp Lagoon (figs. 4, 18). Here, the 1950, 1985, and 2003 shoreline data were used to calculate long-term shoreline change rates using the linear regression method and the 1985 and 2003 shoreline data were used to calculate short-term shoreline change rates using an end-point rate method. Elsewhere, both long-term and short-term rates were calculated using the linear regression method. Region 8 was predominantly erosional ( 79 and 80 percent of transects over the long and short term, respectively). The highest erosion rates in the study were measured in this region, averaging $-0.4 \pm 0.1$ and $-0.5 \pm 0.2 \mathrm{~m} / \mathrm{yr}$ and ranging from -8.3 to $4.1 \mathrm{~m} / \mathrm{yr}$ and -16.0 to 7.2 $\mathrm{m} / \mathrm{yr}$ over the long and short term, respectively (fig. 34, table 5). The highest long-term erosion and accretion rates measured in the region, $>4.0 \mathrm{~m} / \mathrm{yr}$, were associated with the migration of inlets, notably near Singeak and Shishmaref (table 6).

Near the community of Shishmaref (Sarichef Island), mean rates of long- and short-term shoreline change were $-1.0 \pm 0.4$ and $-0.7 \pm 1.4 \mathrm{~m} / \mathrm{yr}$ (ranging from -2.1 to $+4.1 \mathrm{~m} / \mathrm{yr}$ and -2.5 to +7.2 $\mathrm{m} / \mathrm{yr}$, respectively). The net shoreline movement near Shishmaref averaged $-66 \mathrm{~m}$ between 1950 and 2016, with a maximum retreat of $132 \mathrm{~m}$ on the beaches near the east end of the community and maximum accumulation of $+298 \mathrm{~m}$ on the northeasterly migrating spit at the northeast end of the island (fig. 35, table 5).
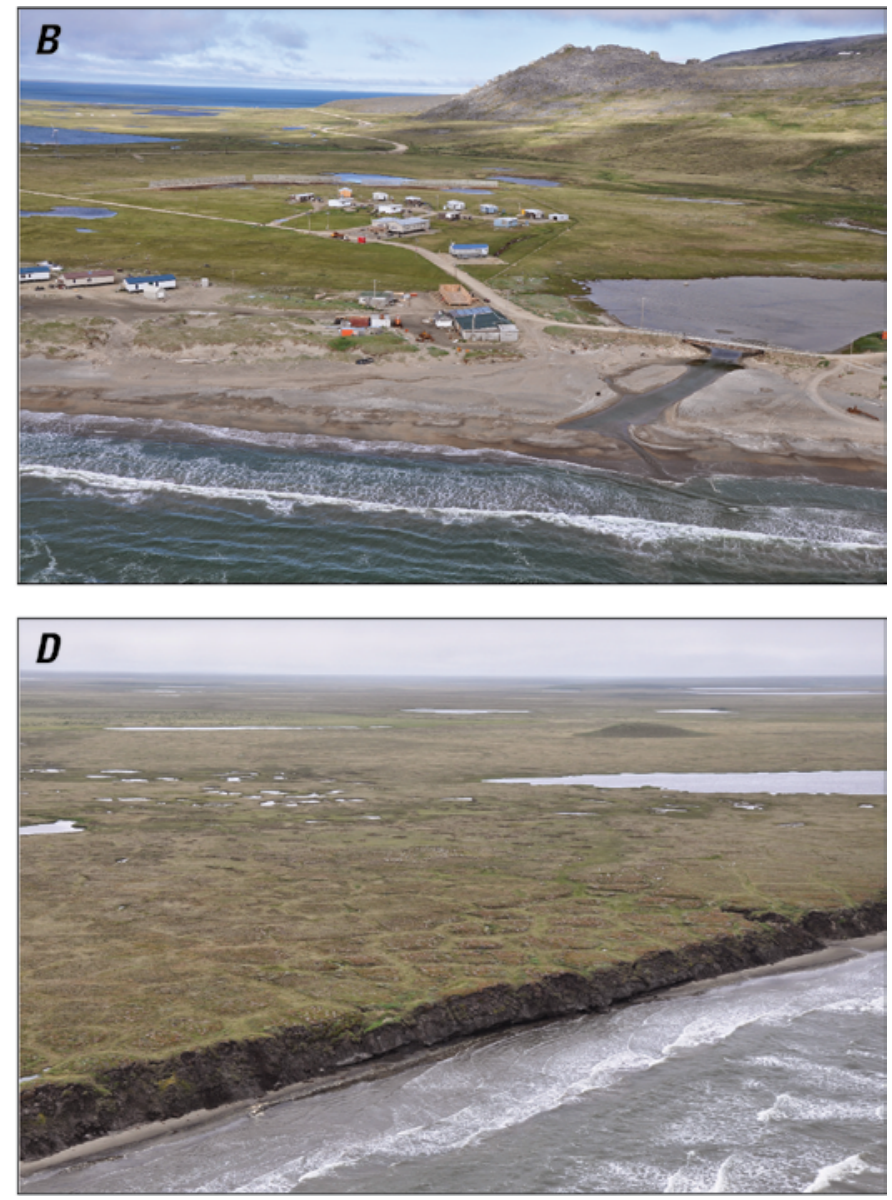

Figure 32. Aerial photographs showing examples of the coast in region 8. $A$, A rock revetment fronts a part of the community of Shishmaref. $B$, Wide beaches front the community of Wales. $C$, The dune-ridge/aggrading spit complex near Cape Espenberg. $D$, Ice-rich permafrost bluffs along the mainland coast east of Singeak. Alaska ShoreZone Program (https://shorezone.org) photographs taken in July 2012 (licensed under Creative Commons 3.0; http://creativecommons.org/licenses/by/3.0/). 
Figure 33. Map showing color-coded shoreline types in region 8 (Sullivan Lake to Cape Prince of Wales). The dashed white outlines near Shishmaref and Wales show the approximate locations of figures 35 and 36 , respectively.

Figure 34. Map showing color-coded shoreline change rates in region 8 (Sullivan Lake to Cape Prince of Wales) between 1950 and 2016. The dashed white outlines near Shishmaref and Wales show the approximate locations of figures 35 and 36 , respectively.

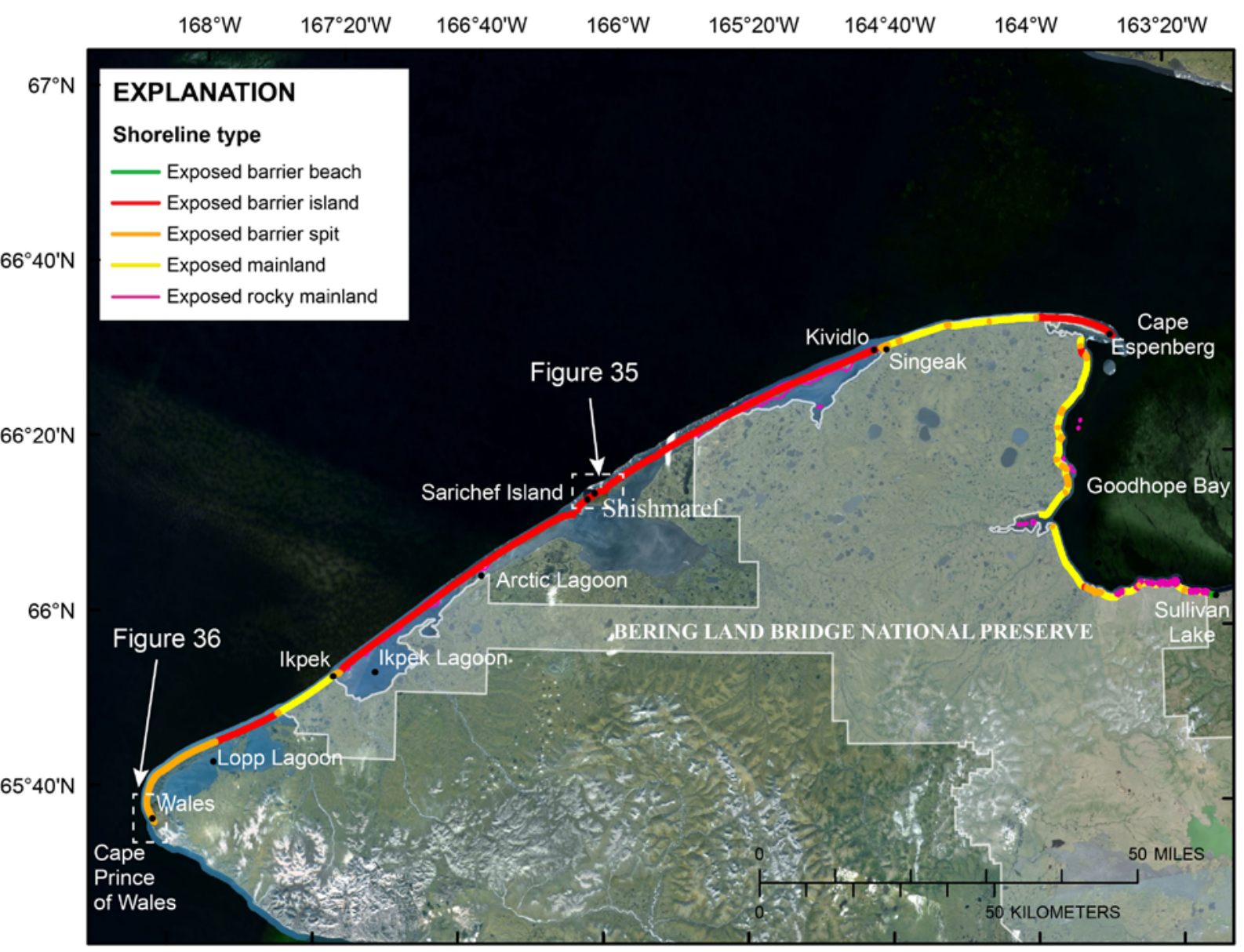

Base image from Alaska Geospatial Council and 2011 National Centre for Space Studies (CNES)
$168^{\circ} \mathrm{W}$
$167^{\circ} 20^{\prime} \mathrm{W}$
$166^{\circ} 40^{\prime} \mathrm{W}$
$166^{\circ} \mathrm{W}$
$165^{\circ} 20^{\prime} \mathrm{W}$
$164^{\circ} 40^{\prime} \mathrm{W}$
$164^{\circ} \mathrm{W}$
$163^{\circ} 20^{\prime} \mathrm{W}$

$67^{\circ} \mathrm{N}$

\section{EXPLANATION}

Shoreline change (1950s-2010s)

(meters per year)

$-<5.0$

-5.0 to -3.0

-3.0 to -1.0

-1.0 to -0.3

-0.3 to 0.3

0.3 to 1.0

1.0 to 3.0

$66^{\circ} 20^{\prime} \mathrm{N}$

3.0 to 5.0

$\longrightarrow 5.0$

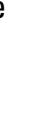

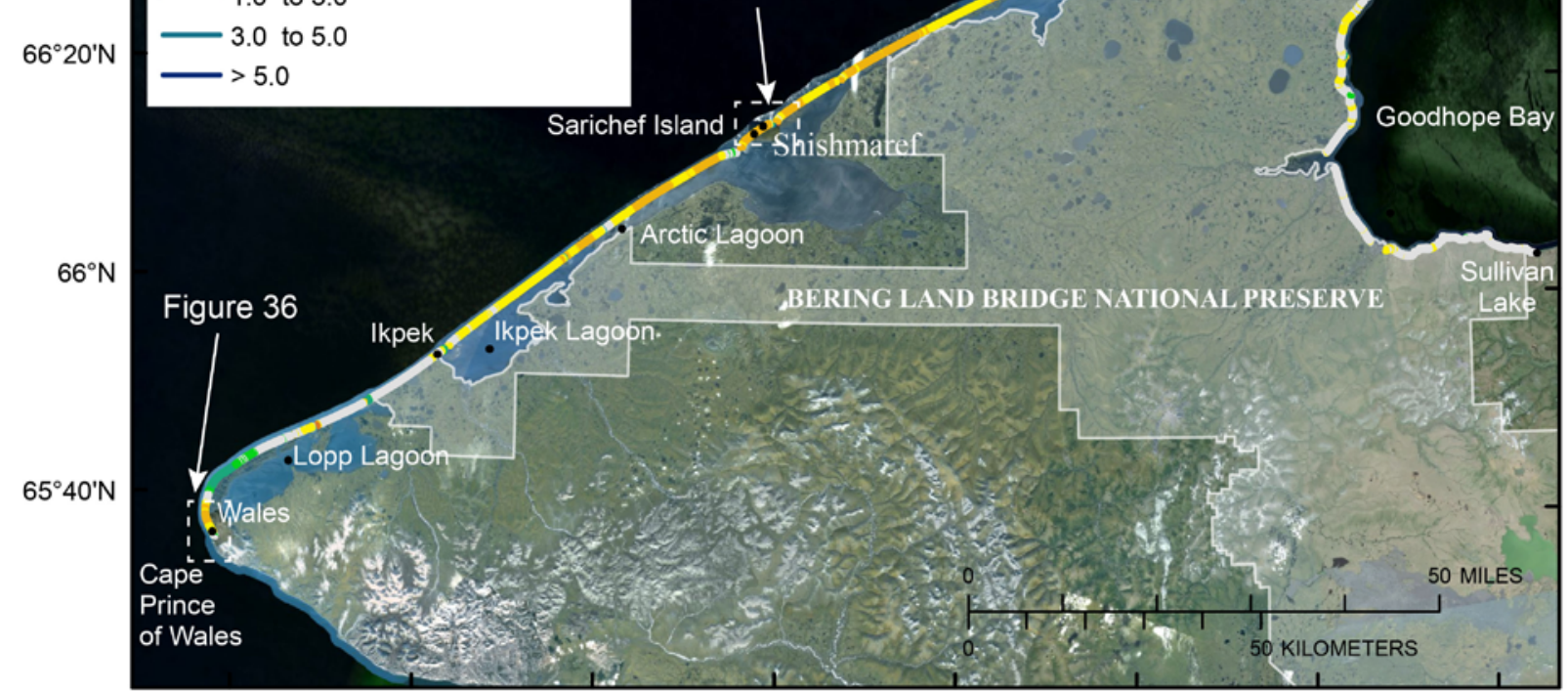

Base image from Alaska Geospatial Council and 2011 National Centre for Space Studies (CNES) 


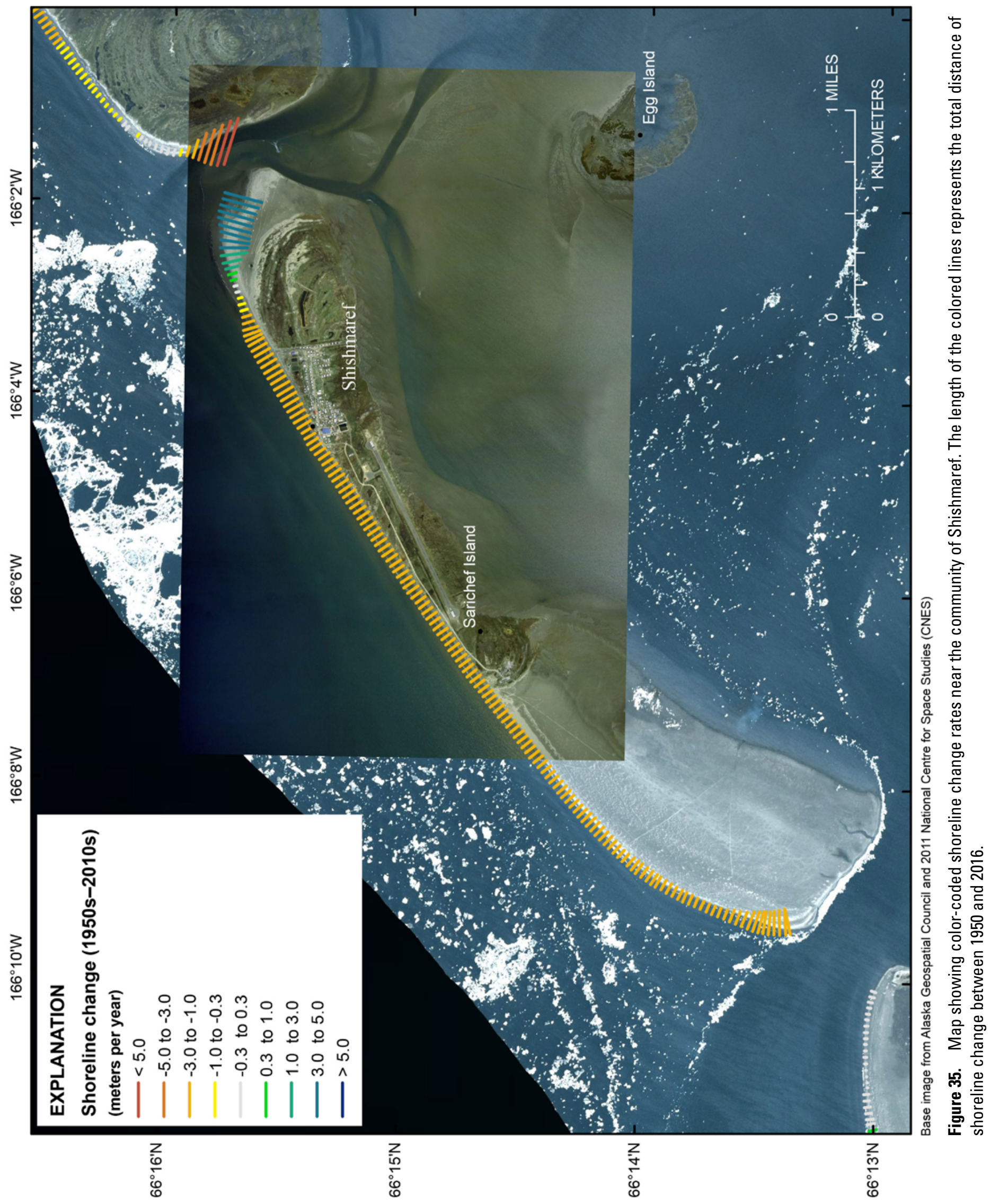


Near Wales, mean rates of long- and short-term shoreline change were $-0.8 \pm 0.7$ (ranging from -0.8 to $+0.5 \mathrm{~m} / \mathrm{yr}$ ) and $-2.1 \pm 1.0 \mathrm{~m} / \mathrm{yr}$ (ranging from -2.1 to $+1.1 \mathrm{~m} / \mathrm{yr}$ ), respectively. The net shoreline movement near Wales averaged $-54 \mathrm{~m}$ between 1950 and 2016, with a maximum retreat of $104 \mathrm{~m}$ on the beaches near the north end of the community and maximum accumulation of $+22 \mathrm{~m}$ south of the community near Cape Prince of Wales (fig. 36, table 5).

\section{Discussion and Additional Considerations}

The total length of coastline evaluated along the north coast of Alaska between Icy Cape and Cape Prince of Wales is approximately $1,270 \mathrm{~km}$. The shoreline change analysis presented in this report covers approximately 92 percent of the coast because of data gaps along rocky coasts, around river deltas, or where historical data are lacking.

Shoreline change rates calculated at over 24,129 individual transects indicate that, between 1948 and 2016, this stretch of coast was slightly erosional, with 68 percent of the total transects showing shoreline retreat over the long term and 63 percent over the short term. Only 9 percent of the total transects measured were eroding at a rate greater than $1 \mathrm{~m} / \mathrm{yr}$ (table 5). The highest rates of both erosion and accretion in the study area were associated with the formation and migration of inlets along barrier island coasts, particularly in front of Kasegaluk Lagoon in region 1, at Point Hope in region 4, and near Singeak and Shishmaref in region 8. Additional areas where shoreline change rates were substantially higher than regional means include Icy Cape, Red Dog Dock, Cape Krusenstern, and southeast of Cape Blossom (fig. 37).

The average rate of shoreline change for the entire study area was $-0.2 \pm 0.1 \mathrm{~m} / \mathrm{yr}$ over the long term (1950s to $2010 \mathrm{~s}$ ) and $-0.2 \pm 0.3 \mathrm{~m} / \mathrm{yr}$ over the short term ( $1980 \mathrm{~s}$ to $2010 \mathrm{~s}$ ). Many rates measured were near the shoreline change rate uncertainty. Shoreline change rates measured at individual transects ranged from -8.3 to $+9.6 \mathrm{~m} / \mathrm{yr}$ over the long term and -16.0 to +20.0 $\mathrm{m} / \mathrm{yr}$ over the short-term periods. The highest erosional rates of change were measured in region 8 in the southern part of the study area between Sullivan Lake and Cape Prince of Wales. The highest accretional rates of change were measured in region 1 in the northeast part of the study area on the barrier islands fronting Kasegaluk Lagoon.

Open-ocean exposed shorelines compose 85 percent of all transects and 70 percent were erosional over the long term. Sheltered mainland-lagoon shorelines compose 15 percent of all transects in the study area and were 58 percent erosional over the long term. Although mean shoreline change rates were quite low along all coasts, small but significant differences were measured with respect to shoreline type and exposure. Exposed shorelines retreated at twice the rate $(-0.2 \pm 0.1 \mathrm{~m} / \mathrm{yr})$ compared to sheltered shorelines $(-0.1 \pm 0.1 \mathrm{~m} / \mathrm{yr})$. Barrier shoreline transects (includes barrier islands, spits, and beaches) composed 49 percent of the total transects and 56 percent of all exposed shoreline transects. Mean shoreline change rates on exposed barrier shorelines were only slightly greater than exposed mainland shorelines $(-0.3 \pm 0.1$ and $-0.2 \pm 0.1 \mathrm{~m} / \mathrm{yr}$, respectively). Mean shoreline change rates on sheltered barrier shorelines were similar to sheltered mainland shorelines $(-0.1 \pm 0.3 \mathrm{~m} / \mathrm{yr})$.

In contrast to the majority of the Nation's shorelines, for all but 3 months of the year (July-September), the north coast of Alaska has historically been protected by landfast sea ice from processes such as waves, winds, and currents that typically drive coastal change on beaches in more temperate regions of the world (Aré, 1988; Reimnitz and others, 1988). Projected and observed increases in periods of sea-ice free conditions, as sea-ice melts earlier and forms later in the year - particularly in autumn, when large storms are more common in the Arctic - suggest that Arctic coasts will be more vulnerable to storm surge and wave energy, potentially resulting in accelerated shoreline erosion and terrestrial habitat loss in the future (Overeem and others, 2011; Barnhart, Overeem, and Anderson, 2014; Farquharson and others, 2018). Increases in air and sea-water temperatures may also increase erosion of the ice-rich, coastal permafrost bluffs present along much of Alaska's Arctic coast (Barnhart, Anderson, and others, 2014; Jones and other, 2018).

\section{Influence of Human Activities}

The influence of local human activities on Alaska's north coast between Icy Cape and Cape Prince of Wales is relatively modest compared to the remainder of the U.S. coastline. Coastal development is limited to seven communities (Point Lay, Point Hope, Kivalina, Kotzebue, Deering, Shishmaref, and Wales), three former DEW radar sites, one active NWS radar site, and Red Dog Dock. Seasonal fishing and whaling camps are scattered along the coast and barge landing sites are common adjacent to the communities. Local residents utilize the coast and nearshore waters extensively for subsistence hunting, fishing, and trapping.

Shore protection structures, primarily sandbags and rockfilled gabion revetments, discontinuously front the coast in some communities. Buildings and municipal infrastructure are located within several hundred meters of the coast and many primary roads, commonly artificially elevated, run along the coast behind the primary berms.

The first large-scale development in the region began in the 1950s with the construction of the DEW line system. Four sites were built on the Arctic coast between Icy Cape and Cape Prince of Wales (Icy Cape, Point Lay, Cape Sabine, and Cape Lisburne; fig. 3). Icy Cape and Cape Sabine were deactivated in 1963. Point Lay and Cape Lisburne were rebuilt as NWS sites and Point Lay was deactivated in 1994. The sites produced large amounts of hazardous waste. Several of the sites are now threatened by coastal erosion and clean-up and remediations are presently underway. Remnant gravel pads and airstrips remain at most of the abandoned locations.

Several communities on the north coast of Alaska, particularly Shishmaref, Kotzebue, and Kivalina, are threatened 


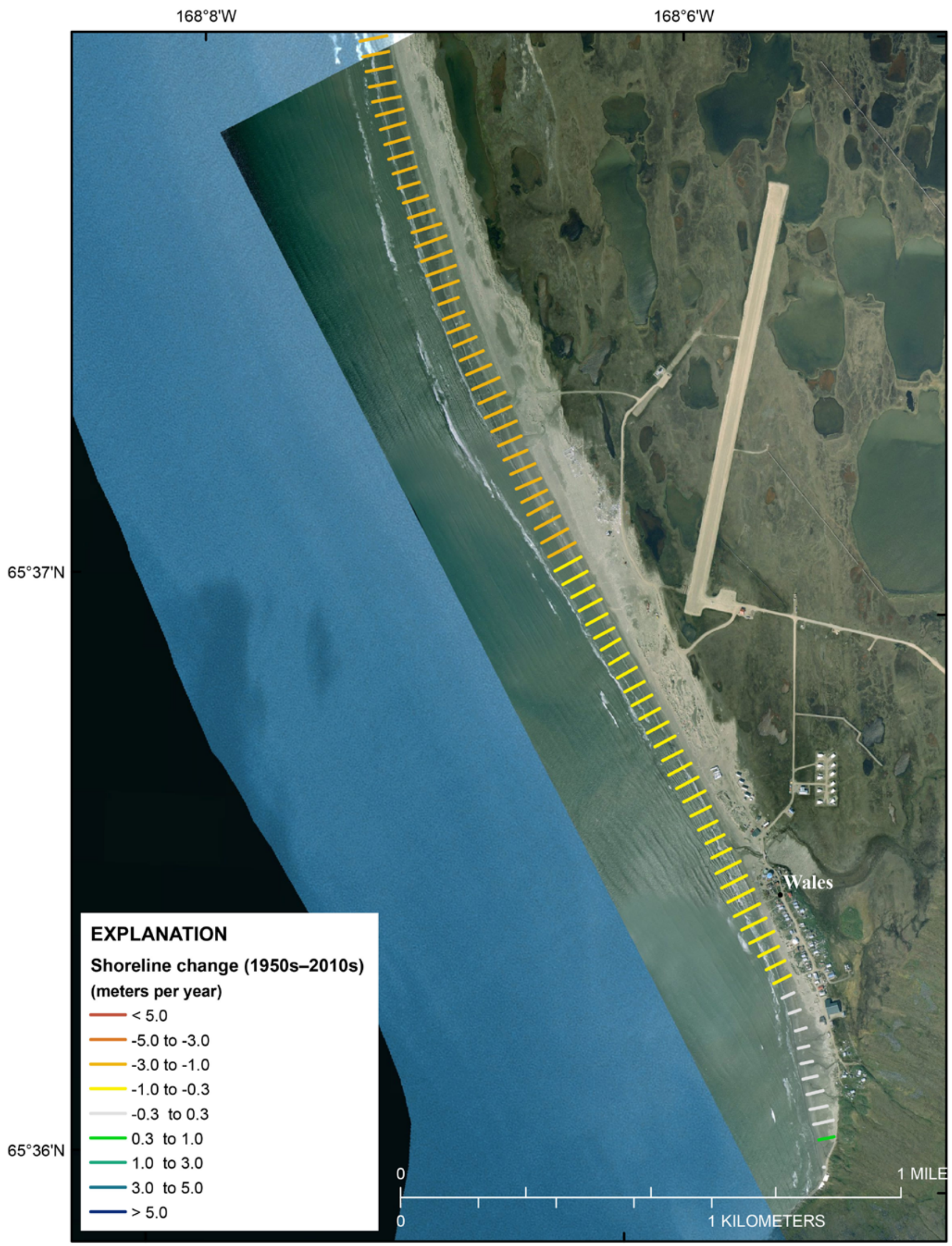

Base image from Alaska Geospatial Council and 2011 National Centre for Space Studies (CNES)

Figure 36. Map showing color-coded shoreline change rates near the community of Wales. The length of the colored lines represents the total distance of shoreline change between 1950 and 2016. 
$160^{\circ} \mathrm{W}$

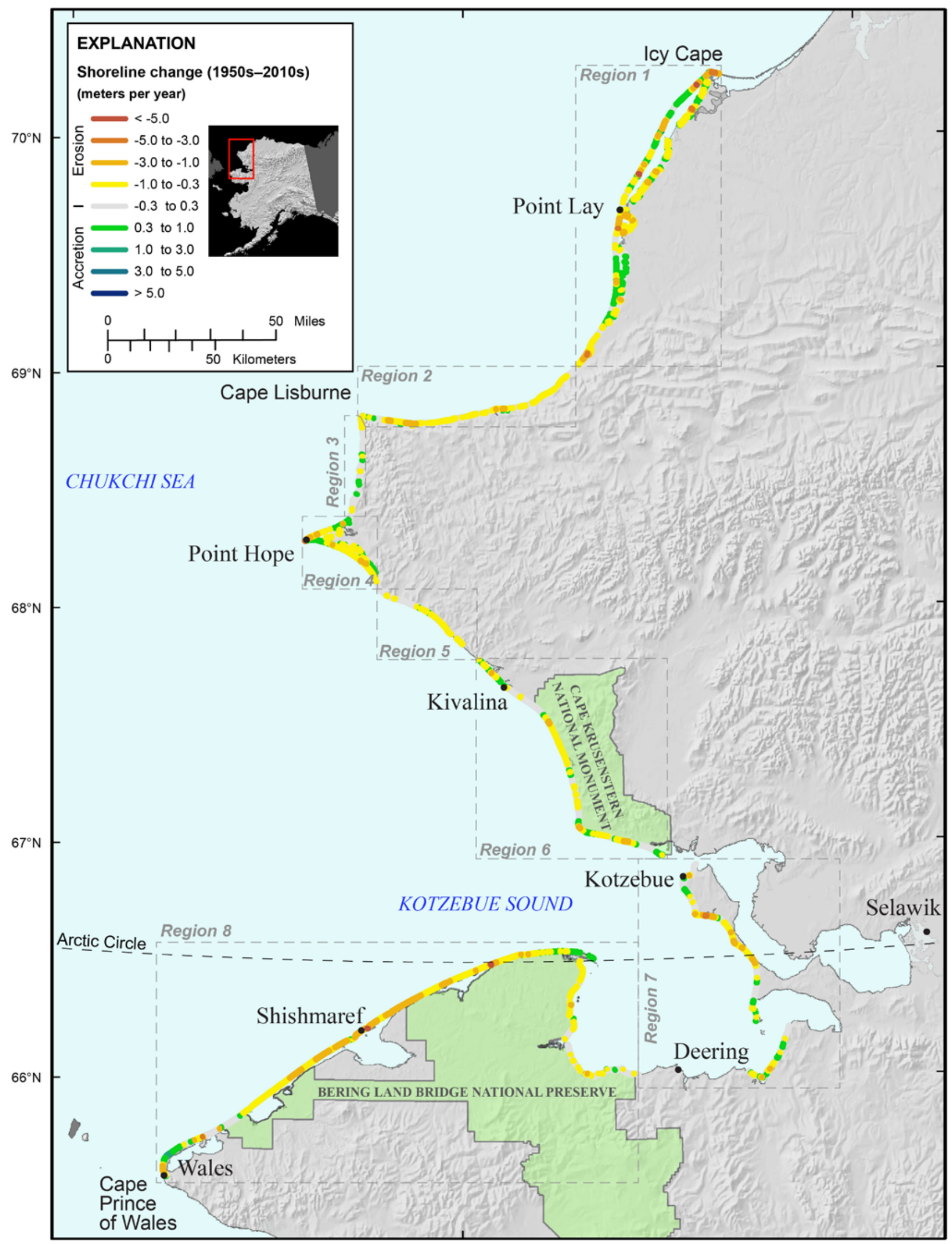

Figure 37. Shaded-relief map of the north coast of Alaska study area showing color-coded, long-term shoreline change rates from Icy Cape to Cape Prince of Wales. The boundaries of the eight study regions (dashed gray outlines) and key geographic locations are also shown. Shaded relief from U.S. Geological Survey 300-meter digital elevation model. 
by the combined hazards of coastal flooding and erosion and are exploring the process of relocating. Warming of the Arctic and decline in the extent of summer sea ice in the Chukchi Sea and Kotzebue Sound (Farquharson and others, 2018, National Snow and Ice Data Center, 2019) is leaving coastlines more exposed to storm-wave events, and increasingly vulnerable to flooding and coastal erosion. Increases in both commercial and recreational shipping traffic in the region and potential development of offshore oil and gas leases in the Chukchi and Beaufort Seas may result in additional coastal development along the Arctic coast.

\section{Planned Updates}

The USGS typically revises and updates rates of shoreline change every 5 to 10 years, or when new data sets are identified and acquired. Therefore, this report and associated data are a work in progress. The revision interval will depend on the availability of new shoreline data and technological advances. Continued monitoring of shoreline change is vital in the coming decades as the dynamics of the coastal environment that lead to beach erosion (for example, sea-level rise, storms, waves, and, in the Arctic, increasing temperature and permafrost degradation) are likely to accelerate with the changing climate.

\section{References Cited}

Alaska Department of Transportation and Public Facilities, 1984, Task Force on Erosion Control Final Report: Alaska Department of Transportation and Public Facilities, 100 p.

Anders, F.J., and Byrnes, M.R., 1991, Accuracy of shoreline change rates as determined from maps and aerial photographs: Shore and Beach, v. 59, p. 17-26.

Aré, F.E., 1988, Thermal abrasion of sea coasts (part I): Polar Geography and Geology, v. 12, no. 1, p. 1-157, https://doi. org/10.1080/10889378809377343.

Barnhart, K.R., Anderson, R.S., Overeem, I., Wobus, C., Clow, G.D, and Urban, F.E., 2014, Modeling erosion of ice-rich permafrost bluffs along the Alaskan Beaufort Sea coast: Journal of Geophysical Research Earth Surface, v. 119, no. 5, p. 1155-1179.

Barnhart, K.R., Overeem, I., and Anderson, R.S., 2014, The effect of changing sea ice on the physical vulnerability of Arctic coasts: The Cryosphere, v. 8, p. 1777-1799.

Crowell, M., and Leatherman, S.P., 1999, Coastal erosion mapping and management: Journal of Coastal Research Special Issue 28, $196 \mathrm{p}$.

Crowell, M., Leatherman, S.P., and Buckley, M.K., 1991, Historical shoreline change-Error analysis and mapping accuracy: Journal of Coastal Research, v. 7, p. 839-852.
Crowell, M., Leatherman, S.P., and Buckley, M.K., 1993, Shoreline change rate analysis-Long-term versus short-term: Shore and Beach, v. 61, no. 2, p. 13-20.

Daniels, R.C., and Huxford, R.H., 2001, An error assessment of vector data derived from scanned National Ocean Service topographic sheets: Journal of Coastal Research, v. 17, no. 3, p. 611-619.

Dolan, R., Anders, F., and Kimball, S., 1985, Coastal erosion and accretion - National Atlas of the United States of America: U.S. Geological Survey, 1 sheet, scale 1:7,500,000.

Dolan, R., Fenster, M.S., and Holme, S., 1991, Temporal analysis of shoreline recession and accretion: Journal of Coastal Research, v. 7, no. 3, p. 723-744.

Douglas, B.C., Crowell, M., and Leatherman, S.P., 1998, Considerations for shoreline position prediction: Journal of Coastal Research, v. 14, no. 3, p. 1025-1033.

Ellis, M.Y., ed., 1978, Coastal mapping handbook: Washington, D.C., U.S. Government Printing Office, U.S. Department of Interior U.S. Geological Survey, and U.S. Department of Commerce National Ocean Survey, 199 p.

Farquharson, L.M., 2017, Arctic landscape dynamics-Modern processes and Pleistocene legacies: Fairbanks, University of Alaska, Ph.D. dissertation, $153 \mathrm{p}$.

Farquharson, L.M., Mann, D.H., Swanson, D.K., Jones, B.M., Buzard, R.M., and Jordan, J.W., 2018, Temporal and spatial variability in coastline response to declining sea-ice in northwest Alaska: Marine Geology, v. 404, p. 71-83.

Fletcher, C., 1992, Sea-level trends and physical consequencesApplications to the U.S. shore: Earth-Science Reviews, v. 33, no. 2, p. 73-109.

Fletcher, C.H., Romine, B.M., Genz, A.S., Barbee, M.M., Dyer, M., Anderson, T.R., Lim, S.C., Vitousek, S., Bochicchio, C., and Richmond, B.M., 2012, National assessment of shoreline change-Historical shoreline change in the Hawaiian Islands: U.S. Geological Survey Open-File Report 2011-1051, 55 p., https://doi.org/10.3133/ ofr20111051.

Fletcher, C.H., Rooney, J., Barbee, M., Lim, S.C., and Richmond, B., 2003, Mapping shoreline change using digital orthophotogrammetry on Maui, Hawaii: Journal of Coastal Research Special Issue 38, p. 106-124.

Galgano, F.A., Douglas, B.C., and Leatherman, S.P., 1998, Trends and variability of shoreline position: Journal of Coastal Research Special Issue 26, p. 282-291.

Garrett, C.J.R., and Toulany, B., 1981, Variability of the flow through the Strait of Belle Isle: Journal of Marine Research, v. 39 , no. 1, p. 163-189. 
Gibbs, A.E., and Richmond, B.M., 2010, Oblique aerial photography of the Arctic Coast of Alaska, Cape Sabine to Milne Point, July 16-19, 2009: U.S. Geological Survey Data Series 503, 4 p. and database, https://pubs.usgs.gov/ds/503/.

Gibbs, A.E., and Richmond, B.M., 2015, National assessment of shoreline change-Historical shoreline change along the north coast of Alaska, U.S.-Canadian border to Icy Cape: U.S. Geological Survey Open-File Report 2015-1048, 96 p., https://doi.org/10.3133/ofr20151048.

Gibbs, A.E., and Richmond, B.M., 2017, National assessment of shoreline change-Summary statistics for updated vector shorelines and associated shoreline change data for the north coast of Alaska, U.S.-Canadian border to Icy Cape: U.S. Geological Survey Open-File Report 2017-1107, 21 p., https://doi.org/10.3133/ofr20171107.

Gibbs, A.E., Ohman, K.A., Coppersmith, R., and Richmond, B.M., 2017, National assessment of shoreline change-A GIS compilation of updated vector shorelines and associated shoreline change data for the north coast of Alaska, U.S. Canadian border to Icy Cape: U.S. Geological Survey data release, https://doi.org/10.5066/F72Z13N1.

Hapke, C.J., Himmelstoss, E.A., Kratzmann, M., List, J.H., and Thieler, E.R., 2010, National assessment of shoreline changeHistorical shoreline change along the New England and Mid-Atlantic coasts: U.S. Geological Survey Open-File Report 2010-1118, 57 p.

Hapke, C.J., and Reid, D., 2006, The national assessment of shoreline change-A GIS compilation of vector shorelines and associated shoreline change data for the sandy shorelines of the California coast: U.S. Geological Survey Open-File Report 2006-1251, https://doi.org/10.3133/ofr20061251.

Hapke, C.J., and Reid, D., 2007, National assessment of shoreline change, part 4 - Historical coastal cliff retreat along the California coast: U.S. Geological Survey Open-File Report 2007-1133, $51 \mathrm{p}$.

Hapke, C.J., Reid, D., and Borelli, M., 2008, The national assessment of shoreline change-A GIS compilation of vector cliff edges and associated cliff erosion data for the California coast: U.S. Geological Survey Open-File Report 2007-1112, https://doi.org/10.3133/ofr20071112.

Hapke, C.J., Reid, D., Richmond, B.M., Ruggiero, P., and List, J., 2006, National assessment of shoreline change, part 3Historical shoreline changes and associated coastal land loss along the sandy shorelines of the California coast: U.S. Geological Survey Open-File Report 2006-1219, 72 p.

Himmelstoss, E.A., Kratzmann, M., Hapke, C., Thieler, E.R., and List, J., 2010, The national assessment of shoreline change-A GIS compilation of vector shorelines and associated shoreline change data for the New England and Mid-Atlantic coasts: U.S. Geological Survey Open-File Report 2010-1119, https://doi.org/10.3133/ofr20101119.
Himmelstoss, E.A., Kratzmann, M.G., and Thieler, E.R., 2017, National assessment of shoreline change-Summary statistics for updated vector shorelines and associated shoreline change data for the Gulf of Mexico and Southeast Atlantic coasts: U.S. Geological Survey Open-File Report 2017-1015, 8 p., https://doi.org/10.3133/ofr20171015.

The H. John Heinz III Center for Science, Economics, and the Environment, 2000, Evaluation of erosion hazards: Washington, D.C., Federal Emergency Management Agency, 203 p.

Jones, B.M., Farquharson, L.M., Baughman, C.A., Buzard, R.M., Arp, C.D., Grosse, G., Bull, D.L., Günther, F., Nitze, I., Urban, F., Kasper, J.L., Frederick, J.M., Thomas, M., Jones, C., Mota, A., Dallimore, S., Tweedie, C., Maio, C., Mann, D.H., Richmond, B., Gibbs, A., Xiao, M., Sachs, T., Iwahana, G., Kanevshiy, M., and Romanovsky, V.E., 2018, A decade of remotely sensed observations highlight complex processes linked to coastal permafrost bluff erosion in the Arctic: Environmental Research Letters, v. 13, no. 11, 13 p., https://doi.org/10.1088/1748-9326/aae471.

Jorgenson, M.T., Kanevskiu, M., Shur, Y., Grunblatt, J., Ping, C.L., and Michaelson, G., 2015, Permafrost database development, characterization and mapping for northern Alaska final report: Arctic Landscape Conservation Cooperative, 49 p., accessed March. 11, 2019, at http://catalog.northslopescience.org/catalog/ entries/4724.

Jorgenson, M.T., Yoshikawa, K., Kanevskiy, M., Shur, Y., Romanovsky, V., Marchenko, S., Grosse, G., Brown, J., and Jones, B., 2008, Permafrost characteristics of Alaska, in Kane, D.L., and Hinkel, K.M., eds., Proceedings of the 9th International Conference on Permafrost: Fairbanks, University of Alaska Institute of Northern Engineering, 1 sheet, scale 1:7,200,000, accessed March 11, 2019, at https://permafrost.gi.alaska.edu/sites/default/files/ AlaskaPermafrostMap_Front_Dec2008_Jorgenson_ etal_2008.pdf.

Kratzmann, M., Himmelstoss, E.A., Ruggiero, P., Thieler, E.R., and Reid, D., 2013, The national assessment of shoreline change-A GIS compilation of vector shorelines and associated shoreline change data for the Pacific Northwest coast: U.S. Geological Survey Open-File Report 2012-1008, https://doi.org/10.3133/ofr20121008.

Lantuit, H., Overduin, P., Couture, N., Wetterich, S., Aré, F., Atkinson, D., Brown, J., Cherkashov, G., Drozdov, D., Forbes, D.L., Graves-Gaylord, A., Grigoriev, M., Hubberten, H.-W., Jordan, J., Jorgenson, T., Ødegård, R.S., Ogorodov, S., Pollard, W.H., Rachold, V., Sedenko, S., Solomon, S., Steenhuisen, F., Streletskaya, I., and Vasiliev, A., 2011, The Arctic Coastal Dynamics database-A new classification scheme and statistics on Arctic permafrost coastlines: Estuaries and Coasts, v. 35, no. 2, p. 383-400, https://doi.org/10.1007/s12237-010-9362-6. 
Lestak, L.R., Manley, W.F., and Parrish, E.G., 2010, Digital shoreline analysis of coastal change in Bering Land Bridge NP (BELA) and Cape Krusenstern NM (CAKR), northwest Alaska: National Park Service Arctic Network I\&M Program digital media.

Manley, W.F., and Lestak, L.R., 2012, Protocol for highresolution geospatial analysis of coastal change in the Arctic Network of Parks: Fort Collins, Colo., National Park Service Natural Resource Report NPS/ARCN/NRR—2012/537.

Manley, W.F., Parrish, E.G., and Lestak, L.R., 2010, Digitized shorelines for the coastal areas of Bering Land Bridge NP (BELA) and Cape Krusenstern NM (CAKR), northwest Alaska: National Park Service Arctic Network I\&M Program digital media.

Manley, W.F., Parrish, E.G., Sanzone, D.M., and Lestak, L.R., 2007a, High-resolution orthorectified imagery from approximately 1950 for the coastal areas of Bering Land Bridge NP (BELA) and Cape Krusenstern NM (CAKR), northwest Alaska: National Park Service Arctic Network I\&M Program digital media.

Manley, W.F., Parrish, E.G., Sanzone, D.M., and Lestak, L.R., 2007b, High-resolution orthorectified imagery from approximately 1980 for the coastal areas of Bering Land Bridge NP (BELA) and Cape Krusenstern NM (CAKR), northwest Alaska: National Park Service Arctic Network I\&M Program digital media.

Manley, W.F., Sanzone, D.M., Lestak, L.R., and Parrish, E.G., 2007c, High-resolution orthorectified imagery from 2003 for the coastal areas of Bering Land Bridge NP (BELA) and Cape Krusenstern NM (CAKR), northwest Alaska: National Park Service Arctic Network I\&M Program digital media.

Miller, T.L., Morton, R.A., Sallenger, A.H., and Moore, L.J., 2004, The national assessment of shoreline change-A GIS compilation of vector shorelines and associated shoreline change data for the U.S. Gulf of Mexico: U.S. Geological Survey Open-File Report 2004-1089, https://doi.org/10.3133/ ofr20041089.

Miller, T.L., Morton, R.A., and Sallenger, A.H., 2005, The national assessment of shoreline change-A GIS compilation of vector shorelines and associated shoreline change data for the U.S. Southeast Atlantic Coast: U.S. Geological Survey Open-File Report 2005-1326, https://doi.org/10.3133/ ofr20051326.

Moore, L.J., 2000, Shoreline mapping techniques: Journal of Coastal Research, v. 16, p. 111-124.

Morton, R.A., 1996, Geoindicators of coastal wetlands and shorelines, in Berger, A.R., and Iams, W.J., eds., Geoindicators-Assessing rapid environmental changes in earth systems: Rotterdam, The Netherlands, A.A. Balkema, p. 207-230.
Morton, R.A., and Miller, T.L., 2005, National assessment of shoreline change, part 2-Historical shoreline changes and associated coastal land loss along the U.S. Southeast Atlantic Coast: U.S. Geological Survey Open-File Report 2005-1401, $35 \mathrm{p}$.

Morton, R.A., Miller, T.L., and Moore, L.J., 2004, National assessment of shoreline change, part 1-Historical shoreline changes and associated coastal land loss along the U.S. Gulf of Mexico: U.S. Geological Survey Open-File Report 2004-1043, $45 \mathrm{p}$.

National Oceanic and Atmospheric Administration [NOAA], 2018a, Tides and currents - Prudhoe Bay, AK - Station ID 9497645: National Oceanic and Atmospheric Administration web site, accessed April 8, 2018, at http://tidesandcurrents. noaa.gov/stationhome.html?id=9497645.

National Oceanic and Atmospheric Administration [NOAA], 2018b, Tides and currents - Red Dog Dock, AK - Station ID 9491094: National Oceanic and Atmospheric Administration web site, accessed April 8, 2018, at http://tidesandcurrents. noaa.gov/stationhome.html?id=9491094.

National Research Council Committee on Coastal Erosion Zone Management, 1990, Managing coastal erosion: Washington, D.C., National Academy Press, 182 p.

National Snow and Ice Data Center, 2019, State of the Cryosphere web site, accessed May 9, 2019, at https://nsidc. org/cryosphere/sotc.

Nolan, M., Larsen, C.F., and Sturm, M., 2015, Mapping snowdepth from manned-aircraft on landscape scales at centimeter resolution using structure-from-motion photogrammetry: The Cryosphere, v. 9, no. 4, p. 1445-1463, https://doi. org/10.5194/tc-9-1445-2015.

Overbeck, J.R., Hendricks, M.D., and Kinsman, N.E.M., 2017, Photogrammetric digital surface models and orthoimagery for the continuous coastline, Wales to Platinum, Alaska, segment A-Wales to Teller, in Overbeck, J.R., Hendricks, M.D., and Kinsman, N.E.M., Photogrammetric digital surface models and orthoimagery for the continuous coastline, Wales to Platinum, Alaska: Alaska Division of Geological and Geophysical Surveys raw data file 2017-8A, 4 p., http://doi.org/10.14509/29771.

Overeem, I., Anderson, R.S., Wobus, C.W., Clow, G.D., Urban, F.E., and Matell, N., 2011, Sea ice loss enhances wave action at the Arctic coast: Geophysical Research Letters, v. 38, no. 17, 6 p., https://doi. org/10.1029/2011GL048681.

Reimnitz, E., Graves, S.M., and Barnes, P.W., 1988, Beaufort Sea coastal erosion, sediment flux, shoreline evolution, and the erosional shelf profile: U.S. Geological Survey Miscellaneous Investigations Series Map I-1182-G, 22 p., 1 plate, https://doi.org/10.3133/i1182G. 
Romine, B.M., Fletcher, C.H., Genz, A.S., Barbee, M.M., Dyer, M., Anderson, T.R., Lim, S.C., Vitousek, S., Bochicchio, C., and Richmond, B.M., 2012, National assessment of shoreline change-A GIS compilation of vector shorelines and associated shoreline change data for the sandy shorelines of Kauai, Oahu, and Maui, Hawaii: U.S. Geological Survey Open-File Report 2011-1009, https://doi.org/10.3133/ofr20111009.

Ruggiero, P., Kratzmann, M.G., Himmelstoss, E.A., Reid, D., Allan, J., and Kaminsky, G., 2013, National assessment of shoreline change-Historical shoreline change along the Pacific Northwest coast: U.S. Geological Survey Open-File Report 2012-1007, 62 p., https://doi.org/10.3133/ofr20121007.

Shalowitz, A.L., 1964, Shore and sea boundaries: Washington, D.C., U.S. Department of Commerce Publication 10-1, 749 p.

Snyder, A.G., and Gibbs, A.E., 2019, National assessment of shoreline change-A GIS compilation of updated vector shorelines and associated shoreline change data for the north coast of Alaska, Icy Cape to Cape Prince of Wales: U.S. Geological Survey data release, https://doi.org/10.5066/P9H1S1PV.

State of Alaska, 2019, Alaska Community Database Online: Department of Commerce, Community, and Economic Development web site, accessed August 20, 2019 at https:// dcra-cdo-dcced.opendata.arcgis.com.

Stauble, D.K., and Brumbaugh, R.W., 2003, An assessment of the nation's shorelines, USA: Shore and Beach, v. 71, p. 11-18.

Taylor, J.R., 1997, An introduction to error analysis - The study of uncertainties in physical measurement: Sausalito, California, University Science Books, 327 p.

Thieler, E.R., and Danforth, W.W., 1994, Historical shoreline mapping - (1) Improving techniques and reducing positioning errors: Journal of Coastal Research, v. 10, p. 549-563.
Thieler, E.R., Himmelstoss, E.A., Zichichi, J.L., and Ergul, A., 2009, Digital Shoreline Analysis System (DSAS) version 4.0 - An ArcGIS extension for calculating shoreline change: U.S. Geological Survey Open-File Report 2008-1278, https://doi.org/10.3133/ofr20081278. [Software directly accessible at https:/www.usgs.gov/software/digitalshoreline-analysis-system.]

U.S. Army Corps of Engineers [USACE], 1971, The National shoreline study: Washington, D.C., U.S. Army Corps of Engineers, 62 p., accessed June 20, 2019, at https://www. iwr.usace.army.mil/Portals/70/docs/nsms/Shoreline Study_1971.pdf.

U.S. Army Corps of Engineers [USACE], 2006, Alaska Village Technical Assistance Program-An examination of erosional issues in the communities of Bethel, Dillingham, Kaktovik, Kivalina, Newtok, Shishmaref, and Unalakleet: U.S. Army Corps of Engineers Alaska District, 44 p., accessed June 20, 2019, at http://66.160.145.48/coms/cli/ AVETA_Report.pdf.

U.S. Army Corps of Engineers [USACE], 2009, Alaska Baseline Erosion Assessment study findings and technical report: U.S. Army Corps of Engineers Alaska District, 65 p., accessed June 20, 2019, at https://www. poa.usace.army.mil/Portals/34/docs/civilworks/BEA/ AlaskaBaselineErosionAssessmentBEAMainReport.pdf.

U.S. Bureau of the Budget, 1947, United States National Map accuracy standards: Washington, D.C., U.S. Bureau of the Budget, 1 p.

Wahrhaftig, C., 1965, Physiographic divisions of Alaska: U.S. Geological Survey Professional Paper 482, 52 p., 6 sheets, scale 1:2,500,000. 
Menlo Park Publishing Service Center

Manuscript approved December 18, 2019

Edited by Monica Erdman

Layout by Cory Hurd 


\section{$\frac{\mathbb{3}}{3}$}

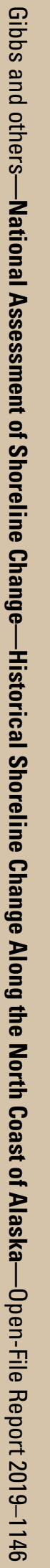

